\title{
CARTAS-PREFÁCiO de TARTAGLia: Matemáticas Práticas no SÉCUlo XVI
}

\author{
Eduardo Henrique Peiruque Kickhöfel \\ Universidade Federal de São Paulo - Unifesp \\ Henrique Marins de Carvalho \\ Instituto Federal de Educação, Ciência e Tecnologia de São Paulo - IFSP
}

(aceito para publicação em agosto de 2021)

\begin{abstract}
Resumo
Niccolò Fontana ou Tartaglia (1500-1557), traduziu para o vernáculo obras fundamentais da matemática de Euclides e Arquimedes. Além disso, em produções inéditas adequadas a uma nova forma de pensar as ciências, aplicou conceitos matemáticos na compreensão da natureza e atuação humana no mundo. O uso da matemática no estudo dos movimentos de corpos, das transações comerciais e até mesmo das artes divinatórias não a remove de sua elevada posição historicamente estabelecida, mas demarca a mudança que a revolução científica traria nos séculos seguintes. Neste artigo, apresentamos as transcrições em italiano e respectivas traduções das cartas-prefácio das seguintes obras do matemático bresciano: Euclide Megarense philosopho: solo introdutore delle scientie mathematice (Euclides Megarense filósofo: único introdutor das ciências matemáticas), La nova scientia de Nicolo Tartaglia (A nova ciência de Niccolò Tartaglia) e General trattato di numeri et misure (Tratado geral de números e medidas), publicadas respectivamente em 1543, 1550 e 1556.
\end{abstract}

Palavras-chave: História da matemática, Renascimento italiano, Tartaglia, Euclides, Tradução.

[TARTAGLiA's PREFACE LETTERS:

Practical Mathematics in The XVI Century]

\begin{abstract}
Niccolò Fontana (1500-1557), or Tartaglia, translated into the vernacular fundamental works of mathematics by Euclid and Archimedes. Moreover, in unprecedented productions
\end{abstract}


appropriate to a new way of thinking about science, he applied mathematical concepts to the understanding of nature and human action in the world. The use of mathematics in the study of the movements of bodies, commercial transactions, and even of the divinatory arts does not remove it from its historically established high position but places a milestone about the transition that scientific revolution would bring in the following centuries. In this article, we present the Italian transcriptions and respective translations of the preface letters to the following works by the Brescian mathematician: Euclide Megarense philosopho: solo introdutore delle scientie mathematice (Euclide Megarense philosopher: sole introducer of mathematical sciences), La nova scientia de Nicolo Tartaglia (The new science of Niccolò Tartaglia) and General trattato di numeri et misure (General treatise on numbers and measurements), published in 1543, 1550 and 1556, respectively.

Keywords: History of mathematics, Italian Renaissance, Tartaglia, Euclid, Translation.

\section{Apresentação}

Este artigo introduz três traduções de cartas-prefácio de livros do matemático italiano Niccolò Tartaglia (c. 1500-57), quais sejam, Euclide Megarense philosopho: solo introdutore delle scientie mathematice (Euclides Megarense filósofo: único introdutor das ciências matemáticas), La nova scientia de Nicolo Tartaglia (A nova ciência de Niccolò Tartaglia) e General trattato di numeri et misure (Tratado geral de números e medidas), publicados respectivamente em 1543, 1550 e 1556. A primeira carta-prefácio está introduzida por uma divisão da matemática e as duas cartas-prefácio seguintes estão acompanhadas pelos índices dos livros que introduzem.

A opção por traduzir esses textos segue uma preceptiva de Benedetto Varchi (c. 1502-1565), humanista, poeta e historiador florentino contemporâneo de Tartaglia, colocada no início de um texto a respeito de prefácios chamado Dei prolegomini o precognizioni (Sobre os prolegômenos ou precognições):

"Sogliono gli spositori greci, i quali non sono meno diligenti che dotti, sempre che esse pigliano a sporre o commentare qual si voglia libro, dichiarare primieramente alcuni capi che se chiamano da loro grecamente Prolegomeni, ciò è cose che si dicono innanzi, e da' filosofi latini, i quali andarono imitando i Greci, Precognizioni, ciò è cose le quali si deono conoscere prima, ciò è sapere innanzi che si venga alla sposizione e dichiarazione del testo; senza i quali capi sarebbe, se non impossibile, certo malagevole intendere perfettamente le cose che in esso libro si contengono e trattano.” (VARCHI, 1859a, p. 805) ${ }^{1}$

\footnotetext{
${ }^{1}$ Varchi (1859a, p. 805): “Costumam os expositores gregos, os quais não são menos diligentes que doutos, sempre que eles pegam para expor ou comentar qual livro se queira, declarar primeiramente alguns capítulos que são chamados gregamente por eles Prolegomeni, isto é, coisas que se dizem antes, e pelos filósofos latinos, os quais andaram imitando os gregos, Precognições, isto é, as coisas as quais se devem conhecer primeiro, isto é, saber
} 
Esses textos, inéditos em língua portuguesa, sugerem pensar a respeito das matemáticas práticas na Itália de meados do século XVI. Naquela época, artífices, humanistas e filósofos valorizavam vita activa de modos inéditos, daí a utilização crescente de conhecimentos matemáticos para fins práticos, que levou a uma física matemática progressivamente independente de noções metafísicas nos séculos seguintes, pautada sobre noções de utilidade e eficiência.

\subsection{Obstáculos}

Consultando documentos produzidos na época de Tartaglia, entende-se que aquela civiltà ${ }^{2}$ tinha características significativamente diversas do mundo contemporâneo. A gravura que abre o La nova scientia de Nicolo Tartaglia, publicada anteriormente na edição de 1537, mostra em sua parte inferior Euclides recebendo homens que entram em um amplo círculo, como visto na Figura $1 .^{3}$

Sem conhecer matemáticas, não era possível entrar nesses círculos de disciplinas, como diz a frase na parte superior que repete um dito platônico: "Nemo huc geometrie expers ingrediatur.” 4 Na gravura, o próprio Platão segura a faixa que traz essa frase e, junto com Aristóteles, ele guarda a entrada do círculo pequeno na parte superior da gravura no qual está uma figura que representa a filosofia. Entre eles e Euclides, estão Tartaglia e quatro disciplinas do Quadrivium, quais sejam, Musica, Aritmetica, Geometria e Astronomia, e ali também está a Prospetiva. Entretanto, junto delas aparecem disciplinas como Pyromantia, Horospitio, Sortilegio e Necromantia, entre outras. ${ }^{5}$ Tartaglia viveu em uma civiltà mais antiga e medieval do que moderna e contemporânea, e talvez seja difícil hoje imaginar que pessoas que viviam naquela época olhavam para os céus e imaginavam que acima existiam esferas cristalinas e corpos celestes feitos de matéria incorruptível, e que após a última esfera de estrelas habitavam anjos em alegria perfeita e infinita, região destinada aos eleitos, como diz Thomas Digges (c. 1546-1595) na gravura A Perfit Description of the Caelestiall Orbes (Uma Perfeita Descrição dos Orbes Celestes), publicada em 1576 (ver Figura 2):

antes que se venha à exposição e declaração do texto; sem os quais capítulos seria, se não impossível, certamente difícil entender as coisas que nesse livro estão contidas e tratadas.” Tradução inédita de Iryna Dahmen Carbonero. ${ }^{2}$ Palavra italiana do século XIV vinda da palavra latina "civilitas", por sua vez derivada do adjetivo "civilis", ou seja, citadino ou civil. Civiltà remete a tradições e ideias de cidades italianas (civitates) que se opunham à rudeza (rusticitas) de habitantes de campos em torno de cidades. Civilidade e urbanidade, ou seja, o estado civil e o estado urbano de um dado povo, talvez sejam boas traduções. $\mathrm{O}$ arco temporal aqui considerado compreende os anos entre 1350 e 1650, aproximadamente. A data inicial faz referência aos primeiros escritos de Francesco Petrarca, e a data final diz respeito à permanência da filosofia aristotélica nas universidades europeias.

${ }^{3}$ Todas as figuras mencionadas no texto estão dispostas após a seção 1.5 em dimensões adequadas para a observação de seus detalhes.

${ }^{4}$ Quem não é perito em geometria não entre.” Nicolau Copérnico (1473-1543) a parafraseia no frontispício do De

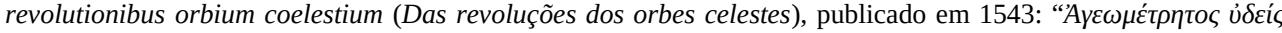

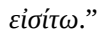

${ }^{5}$ Essas e outras disciplinas aparecem nomeadas na carta-prefácio que Tartaglia escreveu para sua edição de Euclides, traduzida e anotada a seguir.

RBHM, Vol. 21, nº 42, pp. 81-145, 2021 
"This orbe of starres fixed infinitely up extendeth hit self in altitude sphericallye, and therfore immovable the palace of foelicitye garnished with perpetuall shininge glorious lightes innumerable farr excellinge our sonne both in quantitye and qualitye the very court of coelestiall angelles devoid of greefe and replenished with perfite endlesse ioye the habitacle for the elect." (DIGGES, 1605, p. 43) ${ }^{6}$

Embora Tartaglia não discuta diretamente questões teológicas em seus textos, elas faziam parte daquela época. Como Digges, Tartaglia mostra uma curiosa aproximação entre concepções profanas e sacras que vinha do começo da cristandade, a qual implica noções diferentes de filosofia, ciência e arte. Textos de Tartaglia requerem, então, uma série de cuidados.

\subsection{Conceitos e divisões da filosofia}

Os textos aqui traduzidos compreendem fragmentos de uma época distante, restos de uma imensa bricolagem que sobreviveram por miríades de motivos em sua maior parte desconhecidos. Para que se tenha entendimento histórico, descreve-se conceitos e divisões da filosofia, aqui tomados como elementos que articulam questões propostas e talvez esclareçam os textos traduzidos. Segue-se autores da época como Matteo Palmieri (14061475), que no Libro della vita civile (Livro da vida civil), escrito por volta de 1440, diz: "Tosto si conoscerà il primo segno dell'animo bene composto essere stare fermo et seco medesimo, non deviando da' primi ingegni, considerare e rivolgere i termini fondamentali di qualunche scienza o arte, et a quegli con ogni detto et facto conrispondere, sappiendo che ogni altra via è vaga e instabile et sanza fructo."7 Segue-se também Benedetto Varchi, que de modo ainda mais claro diz no começo da segunda das Lezzioni (Lições), publicadas em 1549: "In ciascuna disputa si debbe la prima cosa, per fuggire l'equivocazione e scambiamento dei nomi, dichiarare i termini principali.",

Naquela época, considerava-se filosofia como "divinarum humanarumque rerum

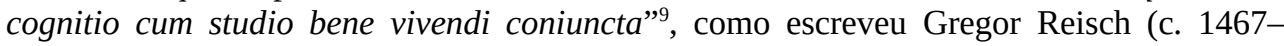

\footnotetext{
${ }^{6}$ Este [é o] orbe de estrelas fixas infinitamente estendido por si próprio em altitude esférica, e desta forma imóvel, [é o] palácio da felicidade, decorado com inumeráveis luzes brilhantes que em muito excedem nosso Sol em quantidade e qualidade, a verdadeira corte dos anjos celestiais desprovida de tristeza e preenchida com alegria perfeita infinita, [sendo] o habitáculo dos eleitos.” As transcrições de edições de época foram feitas pelos autores deste artigo e seguem as normas das transcrições dos textos de Tartaglia.

${ }^{7}$ Palmieri (1529, p. 28v): "Rápido conhecer-se-á o primeiro sinal de uma alma bem composta quando ela está firme e consigo mesma, não desviando dos primeiros engenhos, se ela considera e volta-se aos termos fundamentais de qualquer ciência ou arte, a cada dito e fato correspondendo, e sabe que qualquer outra via é vaga, instável e sem fruto.”

${ }^{8}$ Varchi (1859c, p. 628): "Em qualquer disputa, em primeiro lugar deve-se declarar os termos principais para evitar o equívoco e a troca de nomes.”

${ }^{9}$ Reisch (1503, f. 4v): "Filosofia é conhecimento de coisas divinas e humanas conjuntamente com o estudo do bem viver." Segundo Brower (2014, p. 8), essa definição vem de autores estoicos: “The first definition of wisdom, 'knowledge of matters human and divine' [theiôn te kai anthrôpinôn epistêmê], can be found in the so-called Placita, a treatise which survived in the works of Plutarch (c. 50-120), and which is now usually taken to be an abridgement of a work by Aëtius.” O jesuíta Francisco de Toledo (1532-1596) atribui essa definição a Platão, conforme dito por Cícero, quando declara diverso sentidos de "philosophia” (TOLEDO, 1574, p. 1v): “Aliam
} 
1525) início de seu livro Margarita philosophica (Margarida filosófica), texto publicado em 1503 que teve larga fama ao longo do século XVI. Reich divide a filosofia em duas partes, como mostra a gravura Philosophiae partitio (Figura 3).

Varchi, por sua vez, em um texto escrito por volta de 1550 chamado Divisione della filosofia (Divisão da filosofia), define filosofia como "la cognizione di tutte le cose che sono, così umane come divine, ha per soggetto e materia sua l'ente, ciò è tutto quello che è". ${ }^{10}$ Como Reisch e outros autores, Varchi também divide a filosofia em duas partes. A primeira está dedicada a estudos preparatórios, que ele chama de filosofia racional, embora ele também diga que "vogliono molti che questa non sia veramente parte di Filosofia, ma organo, ciò è strumento che serva alla Filosofia". ${ }^{11}$ A segunda trata de matérias propriamente ditas, que ele chama de filosofia real. Seguindo uma longa tradição vinda de filósofos gregos ${ }^{12}$, Varchi divide a filosofia real em especulativa, pois "il suo fine non è altro che specolare e contemplare, ciò è conoscere e sapere la verità delle cose", e em prática, "meno perfetta [...] perchè il fine suo ultimo non è intendere e sapere, ma operare" ${ }^{13}$ A parte especulativa estava dividida em três partes principais:

"La Filosofia reale specolativa si divide in tre parti: nella Metafisica, ciò è scienza sopranaturale o vero divina; e questa, perchè tratta di tutte quelle cose le quali sono astratte o vero separate da ogni materia, ciò è di Dio e dell'altre Intelligenze, è nobilissima di tutte l'altre scienze. La seconda si chiama Fisica, ciò è scienza naturale, la quale tratta di tutte quelle cose le quali sono in tutto e per tutto sommerse nella materia, ed in somma di tutte le cose naturali, ciò è fatte dalla Natura. La terza ed

definitionem ab ipso objeto sumptam idem Plato tradidit Phaedone, Thaereto, quam Cicero recepit nempè: Philosophia, est diuinarum, humanarumq[ue] rerum cognitio.” Em Reisch e Toledo, vale dizer, coisas humanas e divinas dizem respeito à divindade cristã, não mais a uma divindade profana de origem platônica.

10 Varchi (1859b, p. 794): “A Filosofia, a qual é a cognição de todas as coisas que existem, humanas ou divinas, tem por argumento e matéria o ente, ou seja, tudo aquilo que existe.”

11 Varchi (1859b, p. 794): "Muitos querem que esta não seja verdadeiramente parte da Filosofia, mas órgão, isto é, instrumento que serve à Filosofia."

${ }^{12}$ A origem de conceitos e divisões em questão está em Platão. No Político (258e), Platão escreve a respeito de "classificar todas as ciências (epistêmas) em dois aspectos". Então, ele fala da aritmética (arithmetikê) e de outras artes (têchnai) "separadas da ação e dirigidas apenas para o conhecimento (gnônai mónon)", e de artes como a "arquitetura ou com qualquer outra forma de construção manual", que são "ligadas originalmente à ação (práxesin)” para que "sejam produzidos corpos que antes não existiam”. Logo a seguir, Platão divide as ciências em prática e puramente intelectual: "Classifiquemos todas as ciências atendendo a este princípio. Demos a uma parte o nome de prática (praktikên) e, à outra, de puramente intelectual (mónon gnostikên).” No Filebo (56d-e), Sócrates estabelece uma distinção entre aritmética de pessoas comuns e aritmética de matemáticos; as primeiras operam com unidades distintas (contando dois exércitos, elas sabem que são distintos), os segundos consideram unidades indistintas (números são unidades sem referentes diretos, como por exemplo exércitos). Aristóteles escreve na Metafísica (993b19-23): “Também é correto denominar a filosofia (philosophian) como ciência da verdade (epistêmên tês aletheias). O fim da ciência teórica (theoretikês) é a verdade, e, da ciência prática (praktikês), é a ação. De fato, se os que sabem agir também investigam de que modo as coisas se dão, estudam-nas não como eternas, mas em relação a algo e agora."

${ }^{13}$ Varchi (1859b, p. 794): “A Filosofia real se divide principalmente em duas partes: a primeira e mais nobre se chama especulativa ou contemplativa, porque seu fim não é outro que especular ou contemplar, isto é, conhecer e saber a verdade das coisas. A segunda e menos perfeita parte se chama prática, porque o seu fim último não é entender e saber, mas operar."

RBHM, Vol. 21, nº 42, pp. 81-145, 2021 
ultima parte si chiama da un verbo greco, che vuol dire imparare, Matematica; e questa tratta di tutte quelle cose le quali sono parte astratte e libere da ogni materia, e parte sommerse e tuffate nella materia, ciò è in verità non si truovano se non in cose materiali, e così in quanto all'essenza e natura loro sono materiali, ma si considerano e diffiniscono come se non fussero in materia nessuna; e però quanto alla diffinizione si chiamano immateriali. E queste, ciò è le Matematiche, sono principalmente quattro: Aritmetica, Musica, Geometria, Astrologia o più veramente Astronomia; sotto la quale si contengono molte altre, come Cosmografia, Prospettiva ed altre cotali.” (VARCHI, 1859b, p. 794) ${ }^{14}$

Varchi associa filosofia a noções teológicas cristãs, às quais as demais disciplinas estavam subordinadas, e introduz as disciplinas matemáticas do Quadrivium. Entretanto, ao contrário de outros autores de sua época, ele coloca a física acima da matemática, não obstante esta tratar de objetos mais abstratos do que aquela ${ }^{15}$, possivelmente devido à baixa reputação de matemáticas aplicadas como astronomia em universidades italianas da época. Então, Varchi divide a parte prática da filosofia em duas partes: “La prima e più degna si chiama agibile, la quale tratta non di cose necessarie, e conseguentemente incorrottibili e sempiterne, come fa la Filosofia reale contemplativa, ma tratta di cose contingenti e fatte dagli uomini, e conseguentemente che possono essere e non essere" ${ }^{\text {"16 }}$, e subdivide-a em três partes: ética ou moral, economia ou familiar, e política ou civil. Ele então diz que " $l a$ seconda ed ultima parte si chiama fattibile, e sotto questa si comprendono tutte le arti chiamate volgarmente Meccaniche". ${ }^{17}$ Esta parte, tratava de conhecimentos práticos

${ }^{14}$ Varchi (1859b, p. 794): “A filosofia real especulativa se divide em três partes: em Metafísica, isto é, ciência sobrenatural ou divina; e esta, porque trata de todas aquelas coisas que são abstratas ou separadas de qualquer matéria, isto é, Deus e as outras inteligências, é a mais nobre de todas as ciências. A segunda se chama Física, isto é, ciência natural, a qual trata de todas aquelas coisas em tudo e por tudo submersas na matéria, e em suma de todas as coisas naturais, isto é, feitas pela natureza. A terceira e última parte se chama por um verbo grego que quer dizer aprender, Matemática; e esta trata de todas aquelas coisas que são em parte abstratas e livres de qualquer matéria, e em parte submersas e mergulhadas na matéria, isto é, que em verdade não se encontram se não nas coisas materiais, e assim quanto à essência e natureza são materiais, mas que se consideram e definem como se não fossem em nenhuma matéria; e pela definição se chamam imateriais. E estas, isto é, as Matemáticas, são principalmente quatro: Aritmética, Música, Geometria e Astrologia, ou mais verdadeiramente Astronomia, sob as quais estão muitas outras, como a Cosmografia, a Perspectiva e outras como tais.”

${ }^{15}$ Essa distinção vem de Aristóteles, como está na Física (193b-194a), e o vocabulário de Varchi em parte deriva de Anicius Manlius Severinus Boethius (c. 477-524). No De trinitate (Da Trindade), Boécio divide a parte especulatuva (speculatiuae) em três partes, quais sejam, "naturalis, in motu inabstracta" ("natural, não-abstrata quanto ao movimento") que "considerat enim corporum formas cum materia, quae a corporibus actu separari non possunt" ("considera, então, as formas dos corpos com matéria que não podem ser separadas, em ato, dos corpos"), "mathematica, sine motu inasbstracta, haec enim formas corporum speculatur sine materia ac per hoc sine motu" ("matemática, não-abstrata e sem movimento, e esta especula formas dos corpos sem matéria e, por isso, sem movimento"); e "theologica, sine motu abstracta atque separabilis" ("teológica, abstrata e separada quando ao movimento”). Cf. Boethius (1968, p. 8).

16 Varchi (1859b, p. 794): “A primeira e mais digna chama-se agível, a qual trata não de coisas necessárias e, consequentemente, incorruptíveis e eternas, como faz a Filosofia real contemplativa, mas trata de coisas contingentes e feitas pelos homens que, consequentemente, podem ser ou não ser.”

${ }^{17}$ Varchi (1859b, p. 794): “A segunda e última parte se chama factível, e sob esta estão todas as artes chamadas vulgarmente Mecânicas.” 
utilizados para produzir pinturas e esculturas, por exemplo, e máquinas de diversos tipos e cálculos mercantis. Nesse sentido, na segunda das duas Lezzione Varchi analisa passagens do sexto livro da Ética nicomaqueia. Seguindo Aristóteles, ele divide a alma humana em duas partes, "ragione particolare e ragione universale":

"La ragione universale è delle intenzioni universali, cioè non conosce e non considera se non le cose non solo private d'ogni materia, ma spogliate da tutte le passioni et accidenti materiali, e conseguentemente ingenerate et incorruttibili; e questa, la quale è pròpia dell'uomo, si ridivide in due parti: nella ragione superiore, cioè nello intelletto specolativo o vero contemplativo, e nella ragione inferiore, cioè nell'intelletto pratico o vero attivo.” (VARCHI, 1859b, p. 628) ${ }^{18}$

Essa ampla distinção concorda com a divisão bipartida acima. Embora nessa parte Varchi fale dos cinco hábitos do intelecto, as definições de dois desses hábitos, ciência e arte, servem para caracterizar conhecimentos teóricos e conhecimentos práticos em geral. Ciência segundo Varchi era "la cognizione delle cose universali e necessarie $e$ conseguentemente eterne, avuta mediante la dimostrazione”, tradução colada à definição de Aristóteles. ${ }^{19}$ Arte, por sua vez, era "un abito intellettivo che fa con certa e vera ragione di quelle cose che non sono necessarie, il principio delle quali è non nelle cose che si fanno, ma in colui che le fa", tradução também colada à definição de Aristóteles que está em suas discussões éticas. ${ }^{20}$ De fato, eis um par comum em dezenas de fontes de época. Um esquema inédito de Varchi mostra sua divisão, embora de modo diverso de Reisch (Figura 4). ${ }^{21}$

${ }^{18}$ Varchi (1859c, p. 628): “A razão universal é das intenções universais, isto é, não conhece e não considera as coisas se não apenas provadas de qualquer matéria, mas também despidas de todas as paixões e acidentes materiais, e consequentemente não geradas e incorruptíveis. E esta, que é própria do homem, subdivide-se em suas partes: na razão superior, isto é, no intelecto especulativo ou contemplativo, e na razão inferior, isto é, no intelecto prático ou ativo.” No início do livro sexto da Ética nicomaqueia (1139a8-12), Aristóteles diz que "seja assumido que existem duas partes que tem um princípio racional: um que contempla as causas invariáveis (to epistêmonikon), e outro que contempla as coisas variáveis (to logistikon)”.

${ }^{19}$ Varchi (1859c, p. 628): “A cognição das coisas universais e necessárias, e consequentemente eternas, obtidas mediante a demonstração.” Cf. Aristóteles (Et. Nic., VI, 1139b31-32): “Ciência é disposição demonstrativa (héxis apoditikê)." Ciência aqui está no sentido dos Segundos analíticos, livro a que Aristóteles remete logo a seguir.

${ }^{20}$ Varchi (1859c, p. 628): "Um hábito do intelecto que faz com razão certa e verdadeira daquelas coisas não são necessárias, cujos princípios não estão em si, mas naquele que as faz.” Cf. Aristóteles (Et. Nic., VI, 1140a10-11): “Arte (têchne) é disposição produtiva (héxis poietikê) com razão verdadeira (metà lôgou altethoûs).” A palavra “arte” também descrevia ofícios ou profissões que usavam esse tipo de conhecimento prático. O pintor toscano Cennino Cennini, que escreveu o Il libro dell'arte ( $O$ livro da arte) por volta de 1400, deixa claro esses dois sentidos. No primeiro capítulo de seu livro, ele se descreve como "picholo membro essercitante nell'arte di dipintoria” ("pequeno membro em exercício da arte da pintura”), ou seja, do ofício ou profissão da pintura, e então, ao elogiar Giotto di Bondone, escreve que este "ebbe l'arte più compiuta che avessi mai più nessuno" ("teve arte mais completa que tivesse qualquer um”), ou seja, conhecimentos práticos para pintar. Cf. Cennini (2003, p. 62-63) Adiciona-se que, por metonímia, a palavra “arte” também identificava corporações que organizavam homens que tinham e exerciam artes, como por exemplo a Arte della Lana e a Arte dei Medici e Speziali.

${ }^{21}$ Vale dizer que do mundo antigo ao século de Tartaglia, duas divisões da filosofia foram predominantes. A primeira, de feição aristotélica, está mostrada por Reisch e Varchi, cada qual com suas particularidades. Reisch, 
Reisch e Varchi conciliam classificações abstratas vindas de Aristóteles com o conjunto de disciplinas que vinha do mundo antigo chamado Artes liberais, que além do Quadrivium incluía as disciplinas do Trivium, quais sejam, gramática, retórica e lógica. Entretanto, arte aqui significa disciplina, mas não a parte prática da filosofia como descrita acima. De fato, autores da época usavam as palavras "filosofia”, "ciência”, "arte” e "disciplina” de modos indistintos. Por exemplo, no frontispício do General trattato di numeri et misure, Tartaglia escreve a respeito da "l'arte negotiaria, \& mercantile, ma anchor in ogni altra arte, scientia, ouer disciplina”, ou seja, "arte comercial e mercantil, mas também em toda e qualquer arte, ciência ou disciplina onde intervém o cálculo”.

Varchi, na imagem mencionada acima, escreve “filosofia o’ vero scienza”, ou seja, filosofia ou ciência. ${ }^{22}$ Entretanto, pode-se extrair um padrão bipartido geral desses usos. Fontes sugerem que existiam conhecimentos teóricos voltados a contemplar que em geral eram chamados de ciência, mas eventualmente eram chamados de filosofia ou arte, e existiam conhecimentos práticos buscados por seus fins que em geral eram chamados de arte, mas eventualmente eram chamados de ciência. O contexto de cada ocorrência explica se um conhecimento era teórico ou prático. ${ }^{23}$ Em linhas gerais, essa divisão bipartida

por exemplo, coloca o Trivium (gramática, lógica e retórica) na parte teórica da filosofia, ao passo que Varchi coloca o Trivium (mais poética e história) separado da filosofia. A segunda, de origem estoica, divide a filosofia em três partes: ética (dividida em virtudes cardinais), física (compreendendo o Quadrivium) e lógica (que incluía lógica, retórica etc.). Se for considerado que a lógica era instrumento preparatório, então essa divisão segue em linhas gerais a divisão bipartida anterior. Cf. Kickhöfel (2019) para uma análise detalhada de divisões da filosofia do período em questão.

${ }^{22}$ Varchi (1859c, p. 628) sabia dos sentidos diversos de palavras como "arte” e "ciência”: “Questo nome 'scienza' comprende, largamente preso, ancora tutte l'arti, così questo nome 'arte' comprende, preso largamente, ancora tutte le scienze, non ostante che la scienza e l'arte siano abiti differentissimi." ("Este nome 'ciência' compreende, entendido largamente, todas as artes, e o nome 'arte' compreende, entendido largamente, todas as ciências, não obstante o fato que ciência e arte serem hábitos diferentíssimos”) Esses usos vinham de textos antigos, como mostra a citação de Aristóteles na nota 11 deste artigo introdutório, na qual Aristóteles chama "filosofia (philosophian) como ciência da verdade (epistêmên tês aletheias)”. Magnus Aurelius Cassiodorus também mostra como no começo da era cristã se usava indistintamente as palavras “filosofia”, “ciência”, "arte” e “disciplina”. Em seu livro a respeito de disciplinas, ele declara: "Philosophia e[st] diuinarum humanarum reru[m]q[ue]: inquantum homini possibile e[st] probabilis scientia.” ("Filosofia é ciência provável, tanto quanto possível aos homens, de coisas humanas e divinas.”) Além de considerar filosofia como ciência como Aristóteles, Cassiodorus também sugere que a palavra "scientia" pode ser entendida como conhecimento em sentido amplo (quando se diz que se tem ciência de tal e tal coisa, por exemplo). Logo a seguir, ele diz: "Philosophia e[st] ars artium \& disciplina disciplinarum." ("Filosofia é arte das artes, e disciplina das disciplinas.”) Cassiodorus sugere que existem diversos tipos de conhecimentos, uns mais elevados do que outros segundo os três critérios colocados por Aristóteles: quanto mais afastado dos sentidos, menos útil e mais preciso, melhor era tal tipo de conhecimento. Assim, independentemente das palavras utilizadas, Cassiodorus quis dizer que pessoas como ele consideravam certos conhecimentos mais elevados do que outros, ou seja, conhecimentos que forneciam princípios gerais a demais conhecimentos, caso da filosofia primeira, metafísica ou teologia, palavras também intercambiáveis. Transcrições de CASSIODORUS, M. A. Liber Cassiodori senatoris humanarum scientiarum, qui scribitur de artibus et disciplinis saecularium disciplinarum. Ms. 172 [164], f. 13r (Bibliothèque municipale de Valenciennes). Disponivel em: <https://www.e-codices.ch/en/thumbs/csg/0199>. Acesso em: 22 ago. 2021.

${ }^{23} \mathrm{O}$ contexto, justamente, explica usos e sentidos que não estão colocados de modos “claros e distintos”. Por exemplo, Aristóteles considerou a retórica como uma arte ou ciência produtiva e Quintiliano seguiu a divisão tripartida, também considerando-a como arte produtiva. Entretanto, escolas romanas não estavam organizadas como Aristóteles e Quintiliano sugeriram. Elas tinham ciclos de estudos chamados artes liberais, e a retórica era uma dessas artes que preparavam estudantes para cursos superiores (medicina, direito e filosofia). Diversas divisões posteriores, como as divisões de Boécio ou Cassiodorus, tentaram combinar currículos de escolas civis e 
correspondia a conhecer coisas divinas e humanas, ou seja, “necessárias” e que "podem ser ou não ser”. Em suma, filosofia englobava conhecimentos teóricos e práticos dispostas em uma clara hierarquia, que considerava objetos, graus de certeza e fins. Quanto mais afastado dos sentidos, menos útil e mais preciso, melhor era tal conhecimento. ${ }^{24}$

Diversos autores da época mantiveram essa divisão básica. Entretanto, ao longo do período em questão outros autores propuseram modificações importantes, mas ainda sugerindo divisões vindas de filósofos antigos em suas linhas gerais, devidamente cristianizadas. Tartaglia aceitou esse padrão, como ele escreve no início da carta-prefácio do General trattato di numeri et misure traduzida a seguir, embora ele também acene para aproximações inéditas entre matemática, física e artes mecânicas, uma das questões centrais daquela civiltà.

\subsection{Vita activa e as matemáticas práticas}

O período em que Tartaglia viveu teve diversas características distintivas, e uma das principais dizia respeito a valores novos dados à vita activa. Os relevos do Campanile de Florença, realizados por volta de 1340 por Andrea Pisano (1290-1348) e artífices de sua oficina, servem como marcos importantes (Figura 5). Eles representam tanto artes mecânicas quanto artes liberais, que aproximadamente corresponde à divisão bipartida descrita acima. Quando Pisano e seus assistentes fizeram esses relevos, não eram obras de arte $^{25}$, mas sim obras que celebravam publicamente artes e ciências que faziam a vida cívico-religiosa florentina daquela época. ${ }^{26}$

monásticas e, depois, currículos universitários. Nesse contexto, Reisch colocou a retórica na parte teórica da filosofia, mas Varchi coloca-a como instrumento preparatório para estudos de filosofia.

${ }^{24}$ Os dois primeiros critérios estão colocados no primeiro capítulo do primeiro livro da Metafísica; o terceiro critério está no segundo capítulo desse livro.

${ }^{25}$ Por obras de arte, entende-se obras apreciadas principalmente por suas características estético-formais, mesmo que não foram feitas como tais, ideia elaborada a partir da segunda metade do século XVIII. Cf. Shiner (2001). Na época de Tartaglia, pinturas, esculturas e objetos semelhantes tinham funções cívico-religiosas. Johnson (2005, p. 121) coloca essa questão de modo claro: "In this period many of the objects and images produced would have been viewed first and foremost in terms of their patron, function, medium, or iconography, rather being associated with the name of the person who had made them." No caso de funções religiosas, no Scriptum super Sententiis (3,9,1,2,2, ad 3), Tomás escreve: "Fuit autem triplex ratio institutionis imaginum in Ecclesia. Primo ad instructionem rudium, qui eis quasi quibusdam libris edocentur. Secundo ut incarnationis mysterium et sanctorum exempla magis in memoria essent, dum quotidie oculis repraesentantur. Tertio ad excitandum deuotionis affectum qui ex uisis efficacius incitatur quam ex auditis." ("Foi tríplice razão para instituição de imagens na Igreja. Em primeiro lugar, para a instrução de rudes, que são instruídos por elas quase como que por livros. Em segundo lugar, para que o mistério da encarnação e exemplos dos santos estejam melhor [gravados] em [nossa] memória, estando expostas diariamente aos olhos. Em terceiro lugar, para suscitar afetos de devoção, que são mais eficazmente despertados por meio da visão do que pela audição.”) Essa concepção estava ainda presente no período em questão, como sugere Baxandall (1988), e relacionada noções de retórica: imagens visavam docere (ensinar matérias específicas), delectare (manter a atenção do ouvinte ao longo do discurso) e movere (atingir o sentimento do ouvinte a ponto de fazê-lo mudar de opinião). Os relevos de Pisano tinham essas funções.

${ }^{26}$ Uma das características distintivas do período em questão foi tentar conciliar concepções profanas e sacras, que correspondiam a formas de vida cívica e religiosas. Em Lorenzo Valla, por exemplo, existe uma espécie de epicurismo cristão, e em Marsilio Ficino, uma tentativa de conciliação entre platonismo e cristianismo. No centro cívico de Florença, lê-se sobre a porta principal do Palazzo Vecchio "YHS Rex Regum et Dominum Dominantium" ("Jesus rei de reis, senhor de senhores"), colocada por ordens de Cosimo I de Medici em 1551, então duque da Toscana. Em Santa Maria del Fiore, centro religioso de Florença, estão afrescos de Paolo Uccello e Andrea del

RBHM, Vol. 21, n 42 , pp. 81-145, 2021 
Textos de Francesco Petrarca (1304-1374) que polemizam com saberes especulativos estudados em universidades também servem como marcos importantes. Tendo por modelos Cícero e Sêneca, ele visava conhecimentos realizar a excelência humana nesta vida. Ele não considera sapientia as intermináveis discussões silogísticas, as disputationes praticadas Paris e Oxford, mas sim conhecimentos morais em busca de bem viver nesta vida e beatitude na vida a seguir. Coluccio Salutati (1331-1406), seu discípulo e chanceler de Florença por mais de quarenta anos, continuou essa disputa entre disciplinas especulativas e disciplinas morais, em especial em seu tratado De nobilitate legum et medicinae (Da nobreza das leis e da medicina). Tomando a medicina como modelo de conhecimento teórico $^{27}$, Salutati investe contra a ela e coloca-a em posição inferior às leis, que representa conhecimentos práticos. Como diz Ribeiro dos Santos (2002, p. 781), “a Medicina ocupa-se que é exterior ao homem, do seu corpo e do que ele tem em comum com outros seres que lhe são inferiores (os animais)”, mas “a Jurisprudência, pelo contrário, ocupa-se com o que é próprio e exclusivo do homem”, principalmente seu espírito e suas ações em vista de uma vida virtuosa tanto na espera individual como na esfera civil: “Ex quibus manifeste sequitur vitam activam, prout a speculativa divitur, tam in via quam in patria speculationi modis omnibus preferendam.”28

Nessa direção, o Libro della vita civile de Palmieri, já citado acima, utiliza autores romanos como Marco Túlio Cícero em um contexto de progressiva valorização da vita activa, no qual ele visa educar cidadãos para bem viver em uma “optima republica”. Em uma crítica velada a estudos escolásticos que remonta a Petrarca, Palmieri diz: "Io non credo che il leggere ui faccia meglio uiuere: ne anche piu uirtuosi, pero che il fine dogni bene è non quello intendere, mas secondo quello operare.”29 No começo do terceiro livro, Palmieri declara: "Per questo safferma di tutte lopere humane, niuna essere piu prestante, maggiore, ne piu degna, che q[ue]la se exercita per accrescimento, \& salute della patria, \& optimo stato dalchuna bene ordinata republica, alla conseuatione delle quali maximamente sono apti gli huomini virtuosi." 30 Ainda no âmbito de homens que na época se dedicavam aos studia humanitatis, ou seja, ciclo de estudos que compreendia grammatica, rhetorica, poetica, historia e philosophia moralis, Giannozzo Manetti (13961459) também escreveu a respeito da dignidade do homem e de suas artes. Em seu livro De dignitate et excellentia hominis (Da dignidade e excelência do homem), ele louva artífices de sua época, como Filippo Brunelleschi (1377-1446): “Quanto mentis acumine Philippus, cognomento Brunelleschius, architectorum onmium nostri temporis facile princeps, magnum vel potius maximum florentine edis fornicem illum admirabilem nullis lignorum

\footnotetext{
Castagno que celebram John Hawkwood e Niccolò da Tolentino, respectivamente, condottieri que serviram a República Florentina.

${ }^{27}$ Na gravura de Reisch mencionada acima, pode-se ver que a medicina está tanto na parte teórica (chamada justamente de "medicina theorica") como na parte prática (junto com artes mecânicas).

${ }^{28}$ Citado por Ribeiro dos Santos (2002, p. 789): "A vita activa, na medida em que se separa da vida especulativa, tanto neste mundo como na pátria celeste, deve ser preferida de todos os modos à especulação.”

${ }^{29}$ Palmieri (1529, p. 10v): "Não creio que ler nos faça viver melhor nem mais virtuosos, pois o fim de cada bem não é aquele de entender, mas aquele de operar.”

${ }^{30}$ Palmieri (1529, p. 62v): "Por isso se afirma que de todas as obras humanas nenhuma é mais útil, maior e nem mais digna do que aquela que exercita para o incremento e salvação da pátria, e ótimo estado de qualquer república bem ordenada, à conservação das quais especialmente são aptos os homens virtuosos.”
} 
ferrorumve armamentis, incredibile dictu, fabricatus est!" ${ }^{31}$ Brunelleschi havia erguido a cúpula de Santa Maria del Fiore entre 1421 e 1436, e causara assombro não apenas por suas dimensões, mas também pelo pouco uso de madeiras em sua construção. Pouco após, ele louva artes em geral:

"Nostra nam que, hoc est humana, sunt quoniam ab hominibus effecta cernuntur: omnes domus, omnia opida, omnes urbes, omnia denique orbis terrarum edificia, que nimirum tanta et talia sunt, ut potius angelorum quam hominum opera ob magnam quandam eorum excellentiam iure censeri debeant. Nostre sunt picture, nostre sculpture; nostre sunt artes, nostre scientie, nostre [...] sapientie; nostre sunt denique, ne de singulis longius disseramus cum prope infinita sint, omnes adinventiones, nostra omnia diversarum linguarum ac variarum litterarum genera." (MANETTI, 2018, p. 203) ${ }^{32}$

Leon Battista Alberti (1404-1472) escreveu livros que sistematizam três artes já então importantes, quais sejam, De pictura (Da pintura, 1435), com versão em língua vulgar dele próprio no ano seguinte, De re aedificatoria (Da edificação, 1452) e De statua (Da estátua, c. 1460). Em sua versão italiana do De pictura (1436) dedicada a Brunelleschi, ele também louva artes e artífices de seu tempo, especialmente o arquiteto da cúpula:

"Ma poi che io dal lungo essilio in quale siamo noi Alberti invecchiati, qui fui in questa nostra sopra l'altre ornatissima patria ridutto, compresi in molti ma prima in te, Filippo, e in quel nostro amicissimo Donato scultore e in quegli altri Nencio e Luca e Masaccio, essere a ogni lodata cosa ingegno da non posporli a qual si sia stato antiquo e famoso in queste arti.” (ALBERTI, 1973, prólogo) ${ }^{33}$

Brunelleschi também inventara a perspectiva matemática para uso de pintores e escultores, e coube a Alberti, homem letrado, sistematizá-la. Alberti também escreveu um pequeno tratado a respeito de matemáticas chamado Ludi matematici (Jogos matemáticos), que descreve uma geometria prática, que na Itália tinha origens Leonardo Pisano, dito Fibonacci (c. 1170-1242). Leonardo da Vinci (1452-1519), artífice interessado em

\footnotetext{
${ }^{31}$ Manetti (2018, p. 165): “Com quanta acuidade de mente Filippo, de nome Brunelleschi, sem dúvida o príncipe de todos os arquitetos nosso tempo, edificou a grande, ou melhor, a grandíssima cúpula de Florença sem ajuda de traves de madeira e ferro, coisa incrível de dizer.”

${ }^{32}$ Manetti (2018, p. 203): "São nossas, isto é, humanas, porque se vê claramente terem sido feitas por homens: todas as casas, todas as fortificações, todas as cidades, enfim, todas as construções da circunferência da Terra, que são tamanhas e de tal forma admiráveis, que com justiça se deve afirmar, por sua grande excelência, que são obras antes de anjos que de homens. [...] Nossas são as pinturas, nossas as esculturas; nossas são as artes, nossos os conhecimentos, nossas as sabedorias; nossas são, enfim, para que não nos demoremos em falar de uma a uma, uma vez que, na verdade, são infinitas, todas as descobertas, todas as diversidades de línguas e de escritas.”

${ }^{33}$ Alberti (1973, prólogo): "Mas depois que, de um longo exílio em que nós Alberti envelhecemos, eu voltei a esta nossa pátria, a mais ornada de todas, e entendi que em muitos, mas primeiramente em ti, Filippo, e em nosso amicíssimo Donato e naqueles outros [Lorenzo] Ghiberti, Luca [della Robbia] e Masaccio, existe em qualquer obra louvada engenho capaz de rivalizar com qualquer antigo e famoso [artífice] nessas artes.”
} 
matérias de filosofia natural e matemática, mostra que a época possibilitava aproximações inéditas de artes e ciências a ponto de escrever no Codice E: "La meccanica è il paradiso delle scienze matematiche, perché in quella si viene al frutto matematico." ${ }^{34}$ Leonardo lera Arquimedes, conhecido desde que Tartaglia desde o século XIII e, influenciado pelo matemático de Siracusa, no fim do século XV fez a primeira sistematização das artes mecânicas pela ciência mecânica no hoje chamado Codice Madrid I. Tartaglia fez parte dessa tradição mecânica e matemática, e no prefácio do General trattato di numeri et misure ele une essa tradição à tradição dos humanistas ao dizer que, não obstante "la parte speculatiua ecceda di nobilta la parte operatiua”, "come dice M. Tullio nel primo de officis, ogni laude della uirtu consiste nell'attione, ouer operatione”35.

Após Tartaglia, inúmeros artífices e matemáticos escreveram tratados que sistematizavam artes mecânicas, como por exemplo Vannoccio Biringuccio (c. 14801539), cujo Pirotechnia (Pirotecnia) foi publicado postumamente em 1540; Georg Bauer (1495-1555), que publicou o De re metallica (Dos metais) em 1556; Jacques Besson (c. 1540-1573), autor do tratado Theatrum instrumentorum (Teatro de instrumentos), publicado por volta de 1571); Agostino Ramelli (1531-c. 1610), autor do Le diverse et artificiose machine publicado em 1588; e Guidobaldo del Monte (1545-1607), autor do Mechanicorum liber, publicado em $1577 .^{36}$

Galileu Galilei (1564-1642) conhecia essa tradição. Além de contato com Guidobaldo del Monte e com artífices do Arsenal de Veneza, em seu período paduano ele tinha em sua casa uma oficina que produzia instrumentos, como o compasso militar, do qual inclusive ele publicou em 1606 um pequeno livro La operazione del compasso geometrico et militare (A operação do compasso geométrico e militar). Nos Discorsi e dimostrazioni matematiche intorno a due nuove scienze (Discursos e demonstrações matemáticas em torno de duas novas ciências), que Galileu fez publicar em 1638, ele segue essa orientação prática e fala claramente a respeito do "uso delle arti e delle scienzie" para "vita civile”. Galileu resume assim três séculos de artes e ciências em função da vida civil, remetendo aos relevos do Campanile do Duomo de e Florença.

Por fim, resta dizer René Descartes (1596-1650) não escreveu ex nihilo, mas tinha atrás de si três séculos de vita activa e de aplicações de ciências em artes. Na sexta parte do Discours de la méthode (Discurso do método), em que ele fala de noções da nova física que então desenvolvia, ele diz:

"Car elles m'ont fait voir qu'il est possible de parvenir à des connaissances qui soient fort utiles à la vie, et qu'au lieu de cette philosophie spéculative qu'on enseigne dans les écoles, on en peut trouver une pratique, par laquelle, connaissant la force et les actions du feu, de l'eau, de l'air, des astres, des cieux et de tous les autres corps qui

\footnotetext{
${ }^{34}$ Leonardo da Vinci (Ms E, f. 8 v): “A mecânica é o paraíso das ciências matemáticas, porque dela se obtém resultados das matemáticas.”

35 "Tanto mais a parte especulativa exceda em nobreza a parte operativa, tanto mais a parte operativa excede não apenas em utilidade a parte especulativa, mas ainda em louvores porque, como diz Marco Túlio [Cícero] no primeiro [livro do] Dos deveres, todo louvor da virtude consiste na ação ou operação.”

${ }^{36}$ Cf. Rossi (2002), em especial o primeiro capítulo.
} 
nous environnent, aussi distinctement que nous connaissons les divers métiers de nos artisans, nous les pourrions employer en même façon à tous les usages auxquels ils sont propres, et ainsi nous rendre comme maîtres et possesseurs de la nature. Ce qui n'est pas seulement à désirer pour l'invention d'une infinité d'artifices qui feraient qu'on jouirait, sans aucune peine, des fruits de la terre et de toutes les commodités qui s'y trouvent, mais principalement aussi pour la conservation de la santé, laquelle est sans doute le premier bien et le fondement de tous les autres biens de cette vie.” (DESCARTES, 1987, pp. 61-62) ${ }^{37}$

\subsection{Niccolò Tartaglia}

Tartaglia fazia parte de uma civiltà ainda fortemente impregnada por ideias oriundas da teologia e da prática religiosa devocional cristã. Além disso, o matemático bresciano não pertencia ao rol de catedráticos de alguma universidade, nem mesmo era contratado como um tutor ou conselheiro de membros da realeza. ${ }^{38}$ Sobre este aspecto, isto é, a reputação que um matemático tinha na Itália do século XVI, Biagioli nos informa que:

"There were two disciplinary and professional types of mathematical practitioners who - although sharing a relevant portion of their mathematical knowledge - remained socially distinct. In the first group we find the book-keepers, the land surveyors, and the engineer-masons. Their professional culture was represented by the chair 'ad arithmetican et geometriam' and by the public teaching of the abacus. Socially and professionally distinct from these practitioners we find the astrologerphysicians represented by the chairs 'ad astrologiam'. Although in some Italian cities arithmetic and basic geometry were not taught at universities but at various city-supported schools, the content and social status of the 'culture of the abacus' was quite homogeneous and its social status consistently much inferior to that of the astrologer-physicians. [...] Therefore, at the beginning of the Renaissance, we find a quite literal socio-professional distinction between 'terrestrial' and 'celestial' mathematicians.” (BIAGIOLI, 1989, pp. 42-43) ${ }^{39}$

\footnotetext{
${ }^{37}$ Descartes (1987, pp. 61-62): “Pois elas me mostraram que é possível chegar a conhecimentos que sejam muito úteis à vida, e que, em lugar dessa filosofia especulativa que se ensina nas escolas, é possível encontrar uma outra prática mediante a qual, conhecendo a força e as ações do fogo, da água, do ar, dos astros, dos céus e de todos os outros corpos que nos cercam, tão claramente como conhecemos os vários ofícios de nossos artífices, poderíamos utilizá-los da mesma forma em todos os usos para os quais são próprios, e assim nos tornar como senhores e possuidores da natureza. O que é de desejar, não apenas para a invenção de uma infinidade de artifícios que permitiriam usufruir, sem custo algum, os frutos da terra e todas as comodidades que nela se encontram, mas também, e principalmente, para a conservação da saúde, que é sem dúvida o primeiro bem e a base de todos os outros bens desta vida."

${ }^{38}$ Um esboço biográfico está em Tartaglia (2013, pp. 33-35).

${ }^{39}$ Faz-se duas observações a esta citação. A palavra "culture" sugere dois conceitos de meados do século XIX formulados por Matthew Arnold, em Culture and Anarchy, e Edward Burnett Tylor, em Primitive Culture. Arnold (2006, p. 5) considerava cultura como "a pursuit of our total perfection by means of getting to know, on all the
} 
A vasta quantidade de citações de autores e obras, feita por Tartaglia em sua apresentação da tradução dos Elementos de Euclides, abrangendo diversas áreas do conhecimento, pode ser entendida como uma estratégia de promoção própria, deixando latente seu conhecimento das ideias de Pitágoras, Arquimedes e outros filósofos antigos, passando por predecessores como Boécio e Sacrobosco e chegando a seus contemporâneos famosos, como Nicolau de Cusa e Luca Pacioli. Nesta coletânea de tratados e enciclopédias, há um argumento central. O aprendizado das disciplinas matemáticas mais abstratas do Quadrivium, a saber a aritmética e a geometria, eram basilares para o desenvolvimento de quaisquer outros conhecimentos, sejam eles associados a questões do mundo empírico, como a ciência dos pesos (em nomenclatura moderna, a mecânica), ao universo, como a astronomia e a adivinhações e sortilégios dos mais diversos tipos, e a questões teológicas, pois sem a geometria não se podia entender a “la guida, \& scorta di nostra salute”, ou seja a guia e a suporte de nossa salvação que era a Sagrada Teologia.

Tartaglia ainda aproveita o texto de abertura da tradução dos Elementos para referir-se à sua obra, publicada havia alguns anos - La nova scientia - na qual tratava de instrumentos bélicos, dizendo que seus conhecimentos a respeito da melhor maneira de posicionar ou mirar a artilharia para combater um inimigo foram obtidas a partir dos mesmos conceitos geométricos e aritméticos que são úteis para o estudo da música ou da arquitetura, como diz France:

"The artist-engineers of Renaissance Italy had long been looking to the classics to assist them in perfecting their arts, but Tartaglia was the first to present this attempt to a wide vernacular audience and in the form of a new axiomatically-based science of ballistics. Thus Tartaglia was a pioneer and an evangelist because his whole endeavour was aimed at convincing his readership and patrons that the only route to the perfection of practice, the discovery of useful knowledge, was through the study and application of mathematics to natural phenomena." (FRANCE, 2014, pp. 11-12) ${ }^{40}$

Há, nesta obra, um elemento de inovação saliente. Ao definir bases teóricas para sua nova ciência, Tartaglia a coloca em uma posição de razoável igualdade com as artes práticas (que têm sua importância dada pela obra completada), ao mesmo tempo em que reconhece sua qualidade de descrever - de forma matemática - as regras pelas quais os

matters which most concern us, the best which has been thought and said in the world”, como por exemplo obras de arte, músicas e obras literárias. Tylor (2016, p. 21) considerava cultura como "that complex whole which includes knowledge, belief, art, morals, law, custom, and any other capabilities and habits acquired by man as a member of society”. Neste artigo, evita-se “cultura” e escreve-se “civiltà", palavra explicada na nota 2. A palavra "Renaissance", por sua vez, aponta para um conceito elaborado por Jules Michelet no livro Histoire de France, publicado em 1855. Se esta palavra serve como abordagem inicial, existem alternativas de época, como por exemplo "renovatio", "restitutio", "regeneratio", "reparatio", "revocatio" e "rinascita”.

${ }^{40}$ Anota-se brevemente o anacronismo da palavra “artist”. Na época de Tartaglia, não existiam artistas, ou seja, pessoas que expressam suas próprias subjetividades em obras como pinturas e esculturas, um tipo concebido a partir da segunda metade do século XVIII. Existam artífices, ou seja, pessoas que tinham conhecimentos práticos para produzir seguindo encomendas e contratos. Nesse sentido, consideramos Tartaglia como um matemáticoartífice. 
objetos se movem no mundo, sob certas circunstâncias. Antecipa, portanto, do ponto de vista de método e conhecimento um tipo de ciência que seria desenvolvida por Galileu Galilei e Isaac Newton.

O reconhecimento das matemáticas como conhecimento essencial para diversas artes fica ostensivamente estabelecido no General trattato di numeri et misure, cujos prefácio e sumário traduzidos encerram este artigo. Os mesmos conceitos e práticas operatórias de soma, divisão, porcentagem, conversão de medidas e resolução de equações algébricas constituiriam, então, para o autor, um conjunto essencial de saberes matemáticos para qualquer profissional, fosse este um mercador, um artilheiro ou um astrônomo.

\subsection{Considerações finais}

Este ensaio, que tem por base conceitos e divisões da filosofia, sugere uma abordagem inédita a documentos de época. Em geral, historiadores da arte estudam os relevos do Campanile e o Della pittura, e historiadores da filosofia eventualmente estudam textos de Palmieri e Manetti. Tartaglia, por sua vez, serve como objeto de historiadores da matemática, e estuda-se obras de Galileu em história da ciência ou filosofia da ciência e Descartes, claro, em história da filosofia. Neste ensaio, que considera conceitos e divisões da filosofia da época, esses autores e suas obras fazem parte de história de artes e ciências, em sentido de conhecimentos práticos e conhecimentos teóricos como definidos acima. Dito de outro modo, os textos de Tartaglia que aqui estão traduzidos estão sob uma perspectiva que permite utilizar e aproximar disciplinas contemporâneas como história da arte, história da ciência e história da filosofia, para então colocá-las em segundo plano e, finalmente, descartá-las, como uma escada de que não se precisa mais após subir. Dissolver disciplinas tradicionais, cada qual com seus vocabulários e conceitos, seus métodos e suas questões, e seus textos e autores de referência, talvez seja tarefa a fazer nas próximas décadas.

Estamos no século XXI e não temos ilusões de conhecer como Tartaglia conhecia. Entretanto, tentamos eliminar noções posteriores pensando em termos de usos de certas palavras que produzem sentidos em seus contextos. Dito de modo wittgensteiniano, entendemos que na época de Tartaglia filósofos jogavam jogos diferentes dos jogos que professores jogam hoje em departamentos contemporâneos de filosofia. Assim, nomeamos peças e descrevemos regras daquela época, tanto quanto documentos nos permitem, e nomeamos peças e descrevemos regras desta época em que vivemos para que saibamos ler fontes e escrever a respeito delas. Lá eles jogavam de tais e tais modos, e cá tentamos jogar como eles jogaram sem confundir seus jogos com jogos de cá. De fato, não temos como conhecer o lado de lá da linha, por assim dizer, mas podemos ampliar o lado de cá para que possamos ler e apreciar obras de Niccolò Tartaglia. 


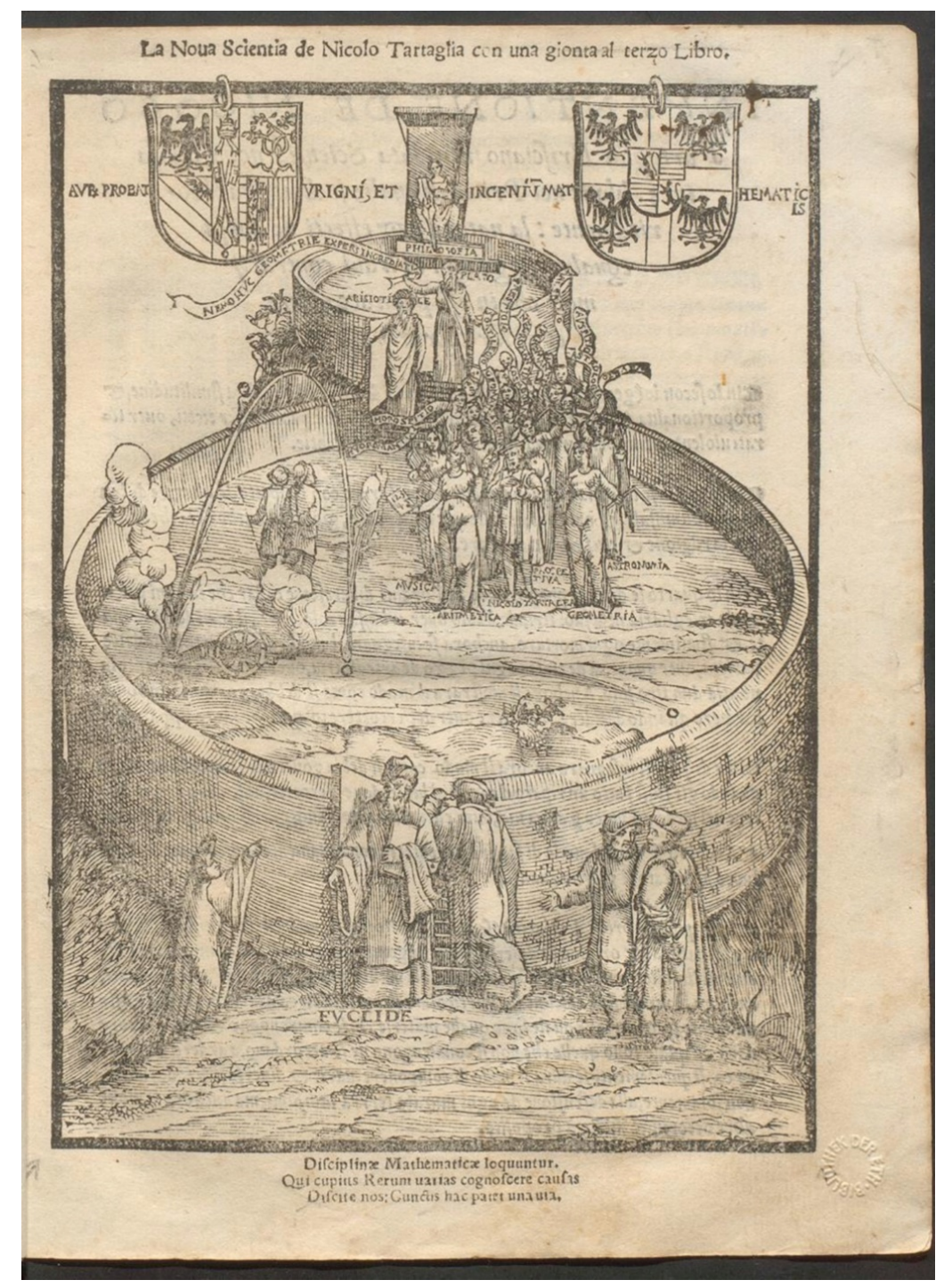

Figura 1 - Página-título de La nova scientia de Nicolo Tartaglia. Fonte: Veneza, 1550. ETH-Bibliothek Zürich 


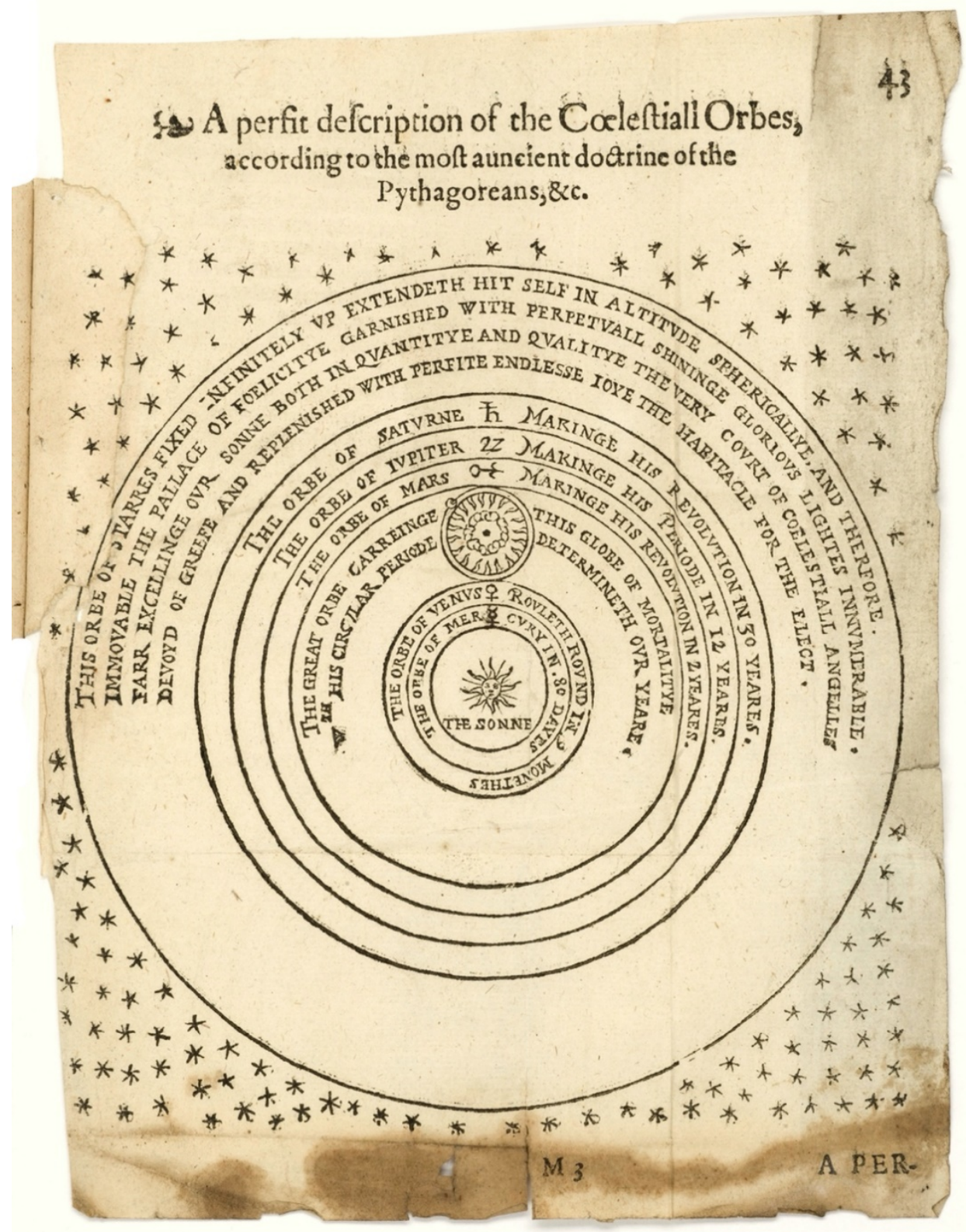

Figura 2 - Thomas Digges. A Perfit Description of the Caelestiall Orbes, da obra A prognostication everlasting of right good effect.

Fonte: Londres, 1576. Royal Society. 


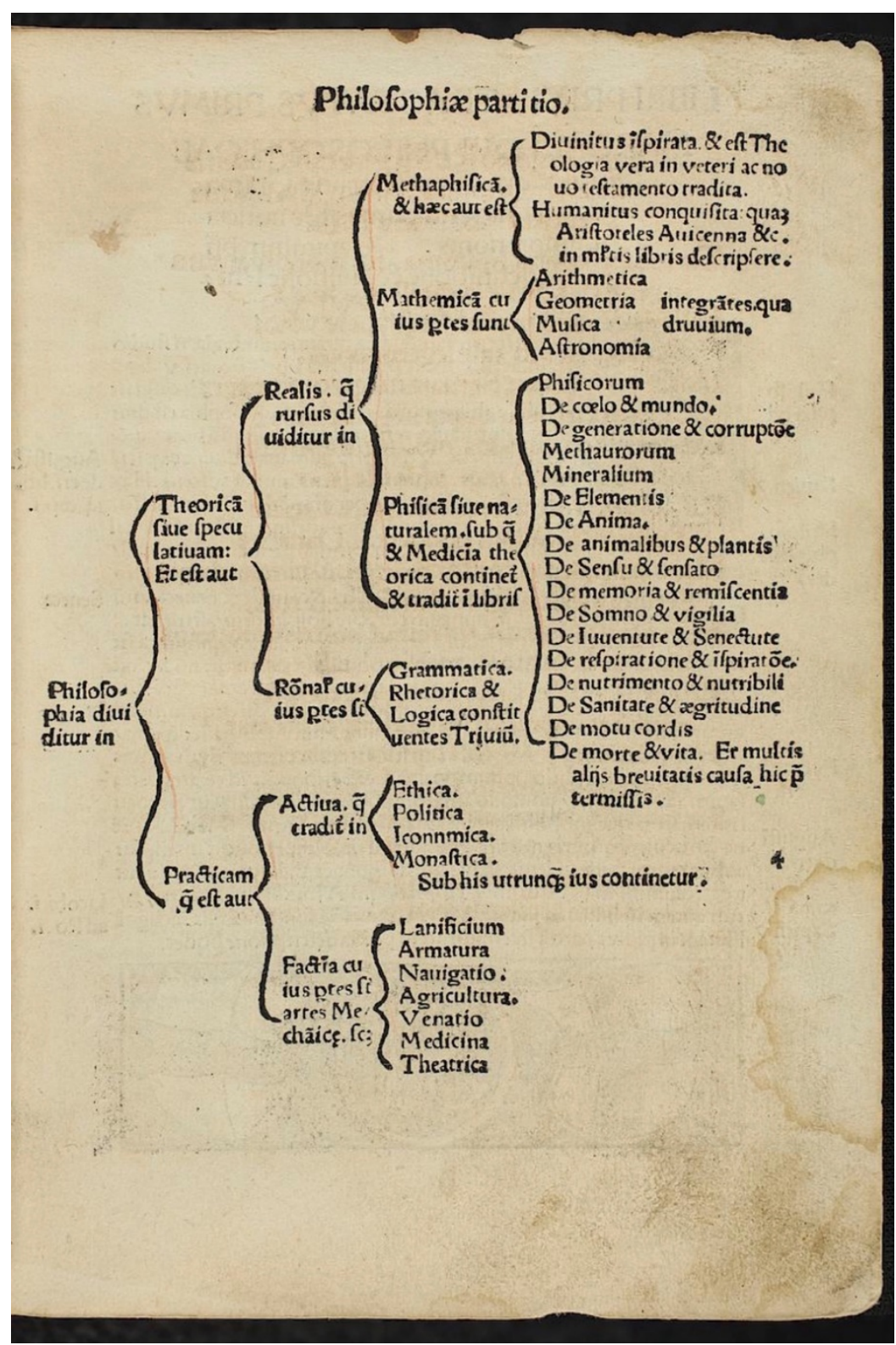

Figura 3 - Gregor Reisch. Margarita philosophica. Freiburg im Breisgau: Johannen Schottum, 1503. Fonte: Universitäts Bibliothek Freiburg . 


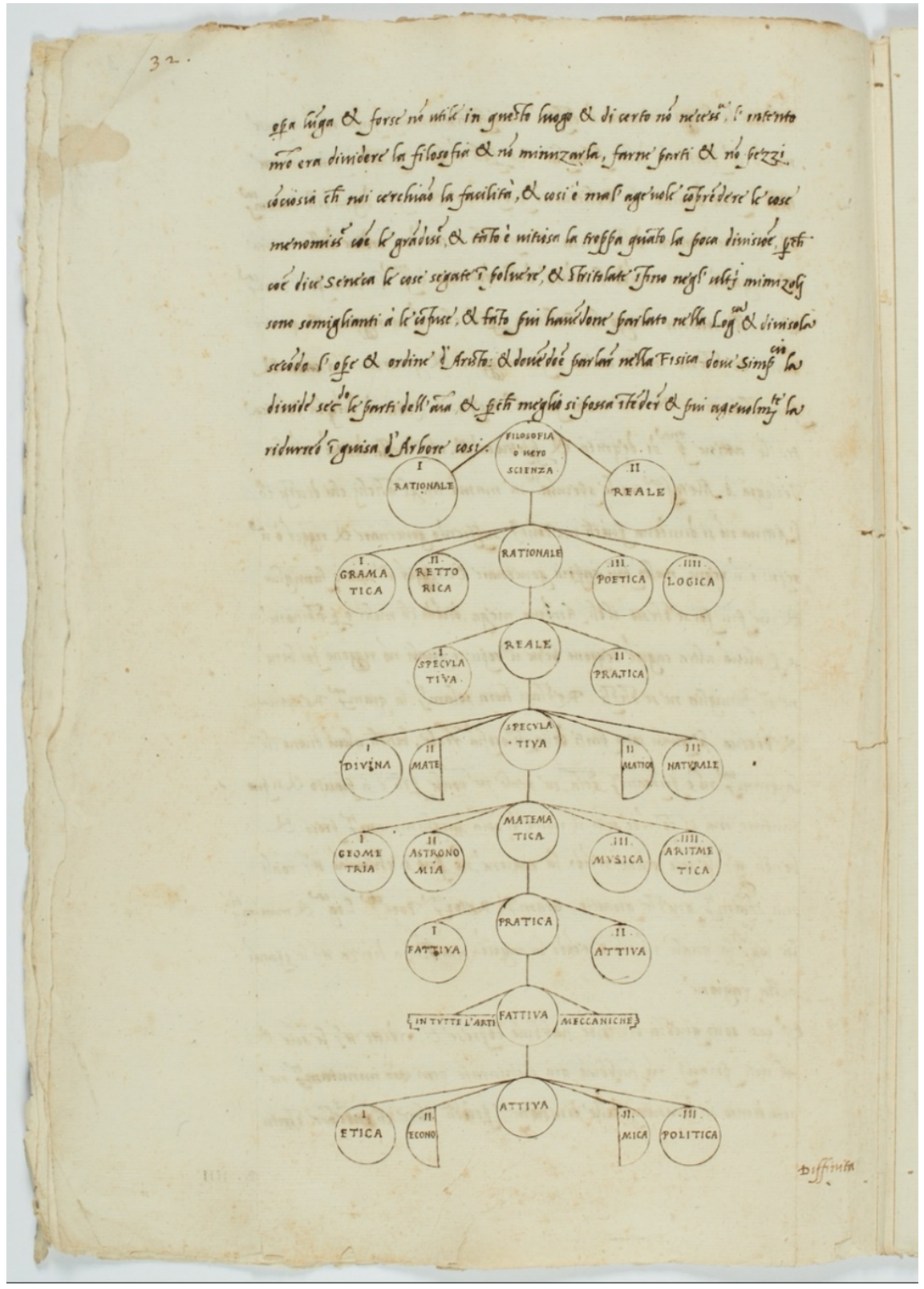

Figura 4 - Benedetto Varchi. Filosofia o’vero scientia. Ms Filza Rinuccini 10, f. 27 v.

Fonte: Biblioteca Nazionale Centrale, Florença. 


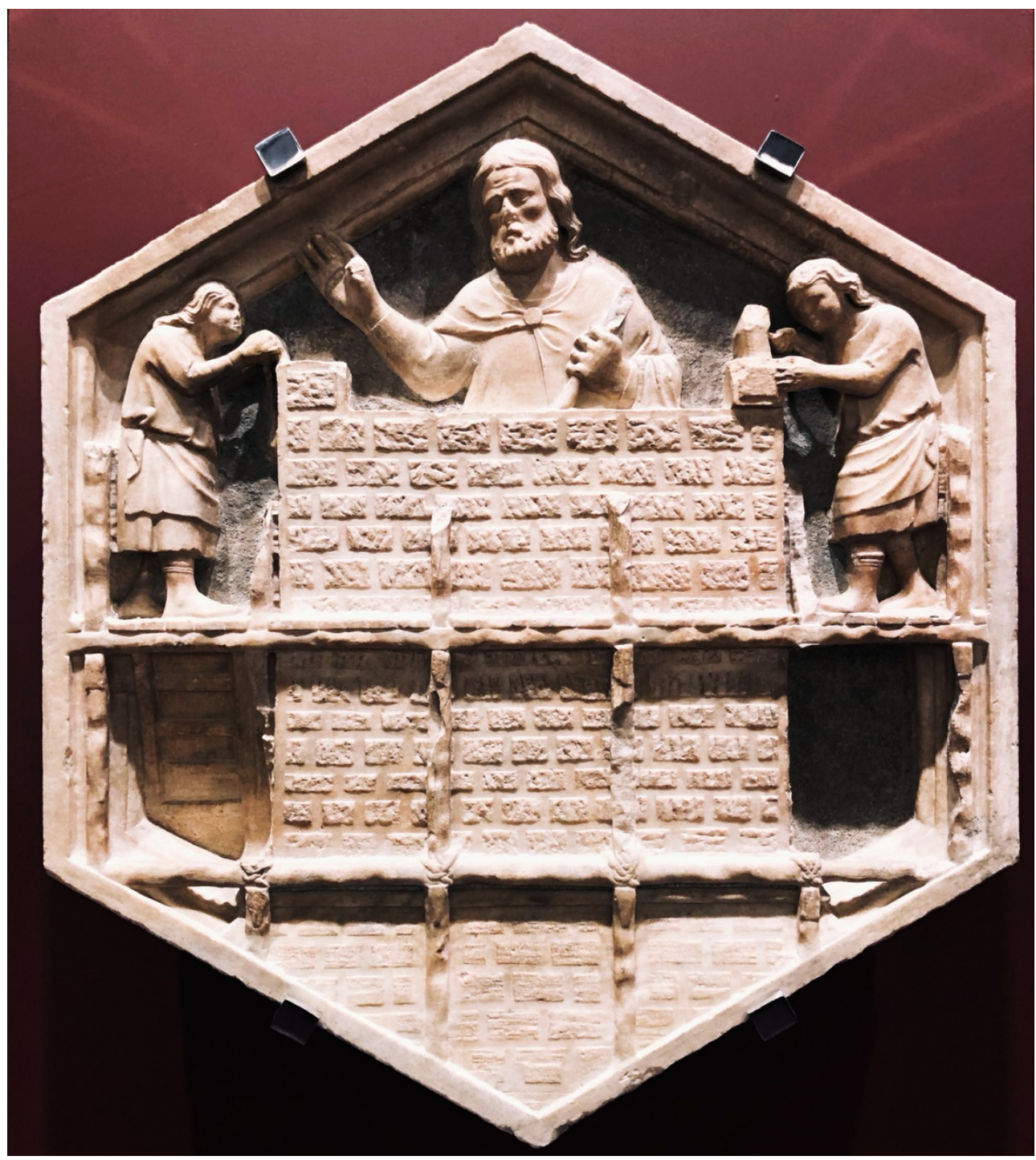

Figura 5a - Andrea Pisano e oficina. Arquitetura. Mármore, c. 1340. Fonte: Museo dell'Opera del Duomo, Florença. Foto: Eduardo Kickhöfel. 


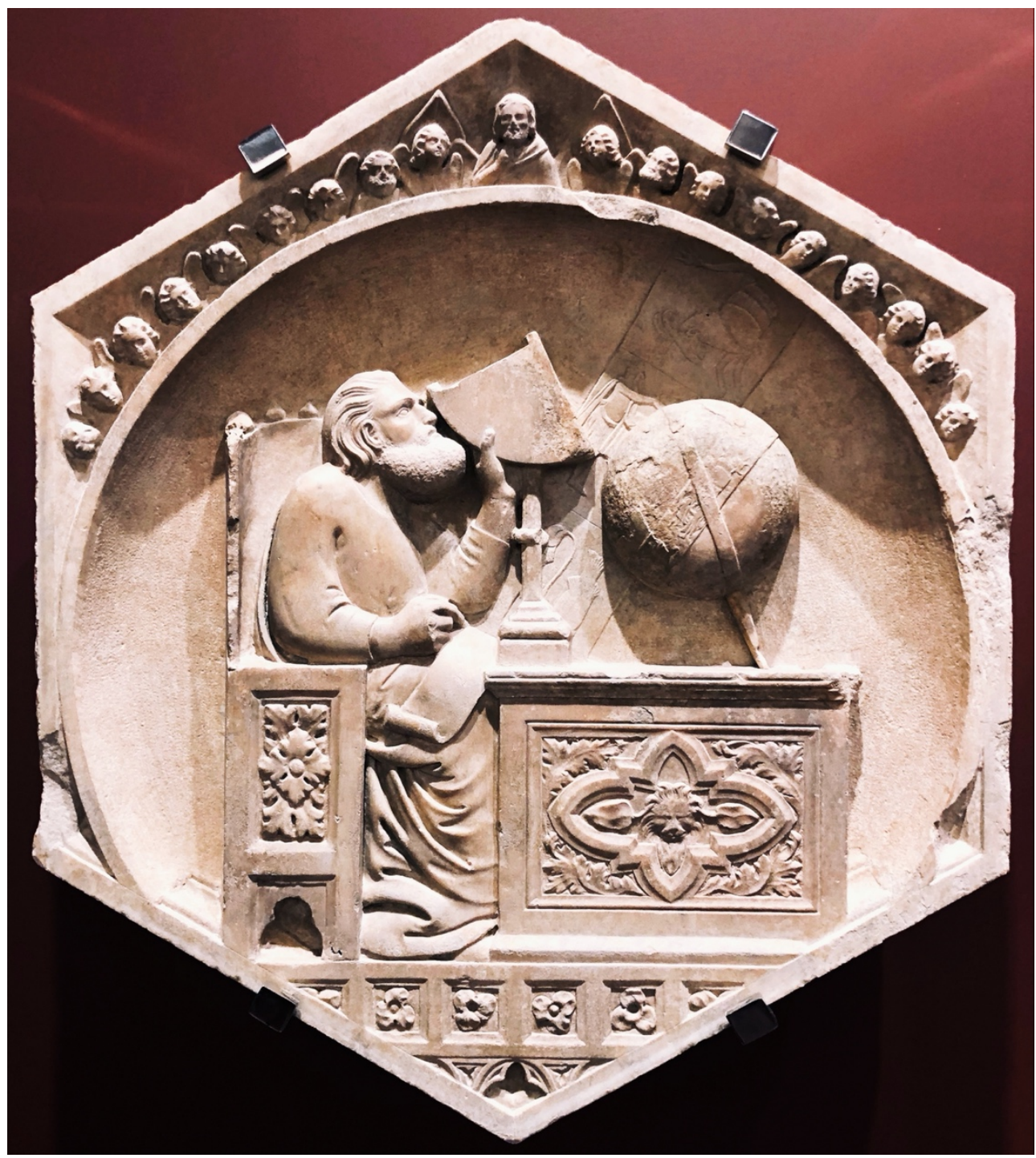

Figura 5b - Andrea Pisano e oficina. Astronomia. Mármore, c. 1340. Fonte: Museo dell'Opera del Duomo, Florença. Foto: Eduardo Kickhöfel. 


\section{Notas às transcrições e traduções}

Para realizar este artigo, as transcrições e as traduções, foram utilizadas as seguintes edições: Euclide Megarense philosopho solo introdutore delle scientie mathematice e La nova scientia de Nicolo Tartaglia, publicadas em Veneza em 1543 e 1550, respectivamente, pertencentes ao acervo da ETH-Bibliothek Zürich e disponíveis na página e-rara.ch; e General trattato di numeri et misure, publicada em Veneza em 1556, do acervo da Bayerische StaatsBibliothek e disponível em formato digital na página Munich DigitiZation Center.

Os textos de Tartaglia sugerem sua formação autodidata. Ele próprio admite sua falta de letras na carta-prefácio do Quesiti et inventioni diverse (Questões e invenções diversas), dedicado a Henrique VIII: "Quantunque in me non sia quella eloquentia, \& ornato dire, che se rechiedera al'udito di uostra Serenità. ${ }^{41}$ " Se comparados com textos de letrados como Benedetto Varchi, por exemplo, os textos do matemático bresciano parecem um tanto rudes. Bernardino Baldi, matemático e poeta italiano do século XVI, em sua Cronica de matematici faz um juízo negativo do estilo de Tartaglia: "Attese nondimeno così poco alla bontà della lingua, che muove a riso talhora chi legge le cose sue. ${ }^{42}$ ” Transcrevêlos e traduzi-los requer diversos cuidados.

As transcrições seguem em linhas gerais normas de transcrições diplomáticas e visam mostrar os textos como foram publicados, tanto quanto possível em uma publicação contemporânea. Os textos seguem sua disposição original, ou seja, sem parágrafos. Não se buscou deixar o italiano de Tartaglia como o italiano contemporâneo. Assim, manteve-se " $u$ " no lugar de " $v$ " (como em "scriue", ou seja, "scrive") e abreviaturas também comuns em textos impressos na época (como em "tēpi”, ou seja, “tempi”). Também estão mantidas grafias inconstantes ("é chiamata” e "è detta"), palavras grudadas ("dellequali”, ou seja, “delle quali”), e evidentes erros de impressão (“maieria”, ou seja, “materia”). Por falta de símbolos, algumas poucas abreviações usadas por Tartaglia estão refeitas entre colchetes (como em "p[ro]portione") e, como não se anota mudanças de linha (feitas com o símbolo "|"), as palavras que estão separadas por linhas e não indicadas por sinais de separação estão refeitas.

As traduções estão coladas aos textos originais, embora às vezes soem estranhas em português. Se em geral usa-se mais artigos definidos em italiano do que em português, manteve-se os usos de Tartaglia. Manteve-se também as palavras maiúsculas originais, e nomes de filósofos estão tal qual Tartaglia os escreveu, excetuando casos óbvios como Platão e Aristóteles. Nas notas, seus nomes estão escritos como usualmente escritos em português. Entretanto, a pontuação em parte prosódica da época de Tartaglia não faz sentido hoje, e certas partes dos textos estão pontuadas de modos talvez pouco convencionais inclusive para aquela época. Assim, fez-se mudanças de pontuação para fins de um texto inteligível em português contemporâneo. A seguir são apresentados os três textos selecionados em suas traduções comentadas (seção 3) e transcrições (seção 4),

\footnotetext{
${ }^{41}$ Tartaglia (1554, f. 4v): "Embora em mim não exista aquela eloquência e escrita ornada, que se requer ao ouvido de vossa Serenidade.”

${ }^{42}$ Baldi (1707, p. 133): “Destinou muito pouco à beleza da língua, que faz rir quem lê suas coisas.”
} 
salientando que as gravuras estão presentes apenas nas traduções, evitando repetições desnecessárias.

\section{Bibliografia}

ALBERTI, Leon Battista. 1973. Della pittura. In: Opere volgari. Ed. a cura di Cecil Grayson. Bari: Laterza, vol. 3, 5-107.

ARISTÓTELES. 1934. Nicomachean Ethics. Translated by H. Rackham. Cambridge, MA: Harvard University Press.

ARISTÓTELES. 1975. Metaphysics. A revised text with introduction and commentary by W. David Ross. Oxford: Oxford University Press.

ARISTÓTELES. 1992. Physics Books I and II. Translated with Introduction, Commentary, Note on Recent Work and Revised Bibliography by William Charlton. Oxford: Clarendon Press.

ARNOLD, Matthew. 2006. Culture and Anarchy. Edited with an Introduction and Notes by Jane Garnett. Oxford: Oxford University Press.

BALDI, Bernardino. 1707. Cronica de matematici. Urbino: Angelo Ant. Monticelli.

BARNEY, Stephen. A., LEWIS, Wendy J., BEACH, J. A., BERGHOF, Oliver. 2006. The Etymologies of Isidore of Seville. Cambridge: Cambridge University Press.

BAROZZI, Marco Fulvio. 2016. Tradizione e traduzione degli Elementi. Disponível em $<$ https://medium.com/through-the-optic-glass/tradizione-e-traduzione-degli-elementi6a644f81fdb6>. Acesso em 08 jul. 2021.

BAXANDALL, Michael. Painting \& experience in fifteenth-century Italy. 1988. Oxford: Oxford University Press.

BIAGIOLI, Mario. 1989. The Social Status of Italian Mathematicians, 1450-1600. In: History of Science, vol. 27, $\mathrm{n}^{\circ}$ 75, 41-95.

BOETHIUS. The Theological Tractates. 1968. Ed. H. F. Steward e E.K. Rand. Cambridge (Mass.); London: Harvard University Press; William Heinemann Ltd.

BROWER, René. 2014. The Stoic Sage: The Early Stoics on Wisdom, Sagehood and Socrates. Cambridge: Cambridge University Press.

BURNETT TYLOR, Edward. 2016. Primitive culture. New York: Dover Publications. 
CASTANHEIRA, Carolina Parizzi. 2009. De institutione Musica de Boécio. Livro 1: tradução e comentários. Dissertação de Mestrado, Faculdade de Letras, UFMG, Belo Horizonte.

CAVAGNA, Veronica. 2007. L’insegnamento dell'aritmetica nel 'General trattato' di Niccolò Tartaglia. In: PIZZAMIGLIO, Pierluigi Ed.) Atti della Giornata di Studio in Memoria di Niccolò Tartaglia Nel 450 Anniversario della Sua Morte. Brescia: [Ateneo di Brescia]. 101-138.

CENNINI, C. Il libro dell'arte. 2003. Ed. a cura di Fabio Frezzato. Vicenza: Neri Pozza Editore.

CICERO. 1991. On Duties. Edited by M. T. Griffin e E. M. Atkins. Cambridge: Cambridge University Press.

DESCARTES, René. 1987. Discours de la méthode. Texte et commentaire par Étienne Gilson. Paris: Vrin.

FRANCE. Catherine Ann. 2015. Gunnery and the Struggle for the New Science (15371687). $\mathrm{PhD}$ Thesis, University of Leeds. Disponível em: <https://etheses.whiterose.ac.uk/7912/>. Acesso em 10 jul. 2021.

GULliNO, Giuseppe. 2019. Gabriele Tadino. In: Dizionario Biografico degli Italiani. Volume 94. Disponível em https://www.treccani.it/enciclopedia/gabriele-tadino_ \%28Dizionario-Biografico\%29/. Acesso em 23 Ago. 2021.

JOHNSON, Geraldine. Renaissance Art. A Very Short Introduction. 2005. Oxford: Oxford University Press.

KICKHOFEL, Eduardo Henrique Peiruque. 2019. Framework para o Renascimento. In: Pensando - Revista de Filosofia, vol. 10, n 21, 3-25.

LEONARDO DA VINCI. 1989. Il manoscritto E. Trascrizione diplomatica e critica di Augusto Marinoni. Firenze: Giunti Barbèra.

LINDBERG, David. C. 1965. The Perspectiva Communis of John Peckham. Michigan: University Microfilms Inc.

MOODY, Ernest. A., CLAGETT, Marshall. 1952. The Medieval Science of Weights (Scientia de Ponderibus) Treatises Ascribed to Euclid, Archimedes, Thabit ibn Qurra, Jordanus de Nemore and Blasius of Parma. Edited with introductions, English Translations and Notes. Madison: The University of Wisconsin Press. 
NAVARRO, Tayra M. C. Lanuza. 2020. Pedro Sánchez Ciruelo. A Commentary on Sacrobosco's Tractatus de sphaera with a Defense of Astrology. In: VALLERIANI, Matteo (ed.) De sphaera of Johannes de Sacrobosco in the Early Modern Period. Berlin: Springer Open, 53-90.

NICOLAU DE CUSA. 2000. De docta ignorantia. Tradução de Jasper Hopkins. Minneapolis: The Arthur J. Banning Press.

PALMIERI, Matteo. 1529. Libro della vita civile. In Firenze per li heredi di Philippo di Giunta nel'anno del Signore M.D.XXIX.

PERINI, Lodovico. 1773. Geometria pratica. Bassano: Remondini di Venezia.

PIERRE D'AILLY. 1531. XIV Quaestiones in Spherae tratctatus Ioannis de Sacro Busto Anglici viri clariss.; Gerardi Cremonensis Theoricae planetarum veteres; Georgii Purbachii Theoricae planetarum novae... Petri Cardin. De Aliaco apiscopi Camaracensis 14 Quaestiones. Venetiis: In aedibus Luceantonii Iunte.

PISANO, Rafaelle; CAPECCHI, Danilo. 2016. Tartaglia's Science of Weights and Mechanics in the Sixteenth Century: Selections from Quesiti et inventioni diverse: Books VII-VIII. Londres: Springer, 2016.

PLESSIS, Paul Jacobus. 1999. An annotated translation of Bartolus' tractatus De fluminibus seu Tyberiadis (Book 1). Mestrado. Potchefstroom: Potchefstroom University for Christian Higher Education.

PTOLOMEU, Claudio. 1984. Almagest. Translated and Annotated por G. J. Toomer. Londres: Duckworth.

PTOLOMEU, Claudio. 1561. La geografia di Claudio Tolomeo Allessandrino. Venetia: Vincenzo Valgrisi.

REISCH, Gregor. 1503. Margarita philosophica. Freiburg im Breisgau: Johannen Schottum.

RIBEIRO DOS SANTOS, Leonel. 2002. Coluccio Salutati e o Paradigma Filosófico do Humanismo. In: Revista Portuguesa de Filosofia, t. 58, fasc. 4, 773-800.

ROSSI, P. 2002. I filosofi e le macchine, 1400-1700. Milano: Feltrinelli.

SCHWARTZ, Randy K. 2004. Issues in the Origin and Development of Hisab alKhata'ayn. Presented at Eighth North African Meeting on the History of Arab Mathematics. Radès: Tunisia. 
SHINER, Larry. 2001. The Invention of Art. Chicago: University of Chicago Press. SIMPLICIUS. 1998. On Aristotle Physics 7. Trad. de Charles Hage. Londres: Bloomsbury Academic.

TARTAGLIA, Niccolò. 1554. Quesiti et inventioni diverse de Nicolo Tartaglia. Venezia: Appresso de l'autore.

TARTAGLIA, Niccolò. 2013. Metallurgy, Ballistics and Epistemic Instruments. The Nova scientia of Nicolò Tartaglia: A New Edition. English translation by Matteo Valleriani, Lindy Divarci and Anna Siebold. Berlin: Edition Open Access.

TOLEDO, F. D. 1574. Francisci Toleti Societatis Iesu Commentaria una cum Quaestionibus in Octo Libros Aristotelis de Physica Auscultatione. Coloniae Agrippinae: Haeredes Arnoldi Birckmani.

TOMÁS DE AQUINO. Scriptum super Sententiis. Disponível em: $<$ https://www.corpusthomisticum.org>. Acesso em 10 jul. 2021.

UNGURU, Sabetai. 1977. Witelonis Perspectivae liber primus. Book I of Witelo's perspectiva. English translation with introduction and commentary and Latin edition. Varsóvia: The Polish Academy of Sciences Press.

VARCHI, Benedetto. 1859a. Dei prolegomini o precognizioni. In: RACHELI, Antonio (ed.), Opere di Benedetto Varchi. Trieste: Sezione Letterario-Artistica del Lloyd Austriaco, v. 2, 805-812.

VARCHI, Benedetto. 1859b. Divisione della filosofia. In: RACHELI, Antonio (ed.), Opere di Benedetto Varchi. Trieste: Sezione Letterario-Artistica del Lloyd Austriaco, v. 2, 794796.

VARCHI, Benedetto. 1859c. Sopra la pittura e scultura: lezione due. In: RACHELI, Antonio (ed.), Opere di Benedetto Varchi. Trieste: Sezione Letterario-Artistica del Lloyd Austriaco, v. 2, 611-647.

VITTORELLI, Paolo. 2014. Il trattato 'Practica musice' di Franchino Gaffurio (1496). Genesi, tradizione del testo, trascrizione interpretativa e traduzione. Doutorado em Musicologia, Universidade de Bologna.

WESTPHAL, Karina Suzana. 2017. De occulta philosophia: magia, humanismo e ceticismo em Cornélio Agrippa. In: Revista Eletrônica de Filosofia, v. 1, nº 1, 117-135. 
Eduardo Henrique Peiruque Kickhöfel

Universidade Federal de São Paulo (Unifesp) -

Campus Guarulhos - Unifesp

E-mail: kickhofel@hotmail.com

\title{
Henrique Marins de Carvalho
}

Instituto Federal de Educação, Ciência e Tecnologia

de São Paulo (IFSP) - Campus São Paulo

E-mail: hmarins@ifsp.edu.br

\section{Traduções}

\subsection{Euclides Megarense filósofo: único introdutor das ciências matemáticas}

\author{
E U C L I D E S M E GA R E N S E \\ F I L Ó S O F O : \\ Ú N I C O I N T R O D U T O R \\ D A S C IÊ NCIAS MA TEMÁ TICAS \\ DILIGENTEMENTE ORDENADO E À \\ INTEGRIDADE TRAZIDO PELO DIGNO \\ Professor de tal ciência Niccolò Tartaglia \\ B R E S C I A N O, \\ Segundo as duas Traduções \\ E POR COMUM COMODIDADE \\ E utilidade do latim ao vulgar \\ Traduzido, \\ C O M U M A A M P L A E X P O S I Ç Ã O \\ DO MESMO TRADUTOR \\ NOVAMENTE ADICIONADA
}

De tal modo clara que qualquer engenho medíocre, sem noção ou intercessão

de alguma outra ciência, com facilidade será capaz de poder entender. 


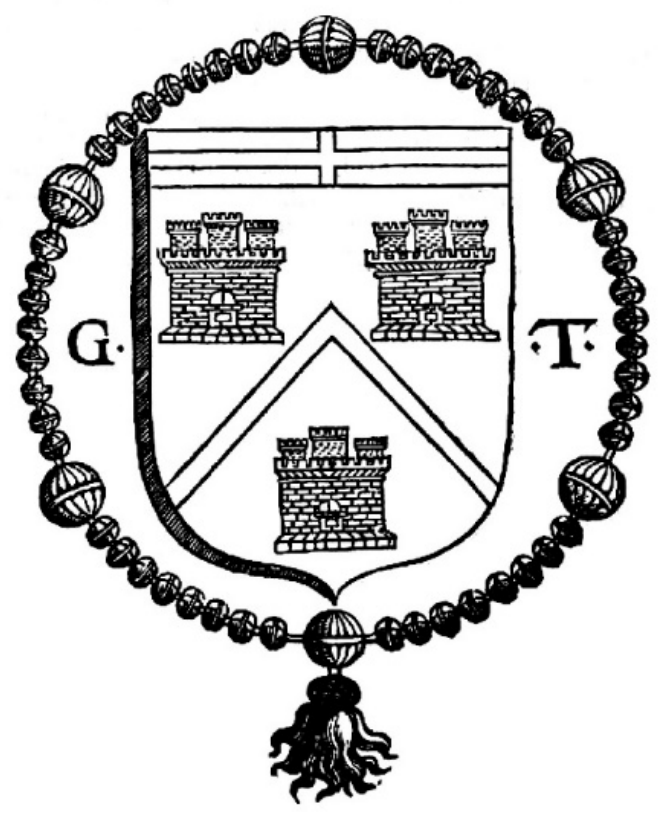

Quais e quantas são as ciências ou disciplinas matemáticas.

As ciências ou disciplinas ditas Matemáticas, segundo o vulgo, são muitas, isto é, Aritmética, Geometria, Música, Astronomia, Astrologia, Cosmografia, Geografia, Corografia $^{43}$, Perspectiva, ciência dos espelhos, ciência dos pesos, Arquitetura e muitas outras. Mas alguns Sábios consideram apenas as quatro primeiras, isto é, Aritmética, Geometria, Música e Astronomia, e dizem ser todas as outras subordinadas, isto é, dependentes das quatro ditas [disciplinas]. Alguns outros modernos (por algumas razões suas) querem que as ditas Matemáticas sejam cinco, porque às ditas quatro [disciplinas] adicionam a Perspectiva. No entanto, o reverendíssimo Pietro de Aliaco, Cardeal, na primeira questão a respeito de Giovanni di Sacrobosco ${ }^{44}$, conclui que a Música e a Astronomia, e semelhantemente a Perspectiva, não são matemáticas puras (como é

\footnotetext{
${ }^{43}$ Ptolomeu define e distingue geografia e corografia no começo de sua Geografia ou Cosmographia. Na tradução de Girolamo Ruscelli, Ptolomeu (1561, p. 1) pergunta: "In che cosa la Geografia sai differente ò diuersa dalla Corografia?" Ele reponde: "La GEOGRAFIA è imitatione del disegno di tutta la parte conosciuta dela Terra, con tutte cose, che vniuersalmente son congiunte. Et è diferente dalla COROGRAFIA; percioche questa, diuidendo $i$ luoghi particolari, gli espone separatamente, \& ciascuno secondo se stesso; et insieme descriue tutte quasi le cose, ancorche minime, le quali in quelle parti, ò in quei luoghi, che ella descriue, son contenuti, sì come sono $i$ porti, le ville, i popoli, i rami, che escono da' primi fiumi, \& l'altre cose simili à queste." ("Em que coisa a Geografia é diferente ou diversa da Corografia? A GEOGRAFIA é imitação do desenho de toda a parte conhecida da Terra, com todas as coisas que são universalmente unidas. E é diferente da COROGRAFIA, porque esta, dividindo os locais particulares, expõe-nos separadamente cada um segundo si mesmos; e ainda descreve quase todas as coisas, ainda que mínimas, que estão naquelas partes, e naqueles locais que ela descreve, estão contidos, como os portos, as vilas, os povos, os ramos que saem dos primeiros rios e outras coisas semelhantes a essas.”).
} 
verdade), mas [matemáticas] médias entre matemáticas e a ciência natural. Disso segue que apenas a Aritmética e a Geometria são matemáticas puras, e todas as outras são [matemáticas] médias, ou dependentes e mistas entre as disciplinas matemáticas e a Filosofia natural, excetuando a Astrologia judiciária, que ele conclui ser pura [disciplina] natural em relação a sua essência.

\author{
A O R E VER E N D O \\ E I L U S TR E \\ S E N HOR \\ GABRIELLE TADINO DA MARTINENGO ${ }^{45}$ \\ CAVALHEIRO DE JERUSALÉM \\ E PRIOR DE BARLETTA, DIGNÍSSIMO \\ SEU SENHOR \\ SEMPRE MAIS RESPEITADO \\ NICCOLÒ TARTAGLIA \\ BRESCIANO
}

TODOS os homens, Reverendo Senhor Prior (como escreve Aristóteles no primeiro [livro] da Metafísica), naturalmente desejam saber. E no primeiro livro dos [Analíticos] posteriores conclui que o saber não é outra coisa que entender por demonstração. E Platão definiu que a sabedoria não é outra coisa que uma cognição das coisas divinas e humanas. E muitos filósofos determinam que as partes da sabedoria são duas, isto é, especulação e operação, ou prática e teórica. E Aristóteles, no segundo [livro] da Metafísica, diz que o fim da especulação, ou da ciência especulativa, não é outra coisa que a verdade, e da operação ou prática, a obra completada. E todos os antigos perscrutadores das coisas afirmam moverse mais [pela] verdade nas matemáticas (isto é, na Aritmética e na Geometria) do que em qualquer outra arte liberal. Por isso, determinam elas estarem no primeiro grau de certeza. Mas veremos (como diz o Cardeal de $\mathrm{Cusa}^{46}$ ) que todos aqueles que experimentam essas

${ }^{44}$ Pierre d'Ailly ou Petrus de Alliaco (1351-1420), cardeal da Igreja católica, escreveu o XIV Quaestiones in Spherae tractatus Ioannis de Sacro Busto (Quatorze questões sobre o tratado da Esfera de Johannes de Sacrobosco). Como diz o título, ele comenta a obra De sphaera mundi (Da esfera do mundo) de autoria do monge e astrônomo Johannes de Sacrobosco (c. 1195 - c. 1256), tratado de astronomia baseado no Almagesto (Almagesto) de Ptolomeu que teve ampla divulgação até o Renascimento. Cf. Valleriani (2020). De acordo com Navarro (2020, p. 65), a primeira questão de Pierre d’Ailly tinha como tema a natureza da matemática e a classificação da astrologia (ou astronomia) como uma ciência matemática média ou mista, assim como a música ou a perspectiva, em uma posição intermediária entre as matemáticas puras (aritmética e geometria) e as ciências físicas, questão que tem origem nos comentários de Tomás de Aquino às questões 5 e 6 do De Trinitate (Da trindade) de Boécio.

${ }^{45}$ Gabrielle Tadino (1478-1583) foi engenheiro militar, interessado nas artes da artilharia e da defesa de fortificações. Um esboço biográfico está em Gullino (2019).

${ }^{46}$ Nicolau de Cusa (1401-1464), influente teólogo e filósofo alemão, aludiu diversas vezes em seus tratados à relação entre o conhecimento matemático e o aperfeiçoamento da vida espiritual. A metáfora do "alimento intelectual”, de acordo com Hopkins (2000) é encontrada nas obras De docta ignorantia (Douta ignorancia), livro IIII-12, De sapientia (Da sabedoria), livro I, De visione Dei (Da visão de Deus) 16, De venatione spaientiae (Da caça à sabedoria) 12 e Sermo (Sermão) VII. Além disso, em De docta ignorantia, livro I, 11, após referências a Pitágoras, Aristóteles, Agostinho e Boécio segue-se esta conclusão: "Prosseguindo neste caminho dos antigos, 
duas disciplinas, principalmente a Geometria, encontram nela um amor admirável, como se nela estivesse o puro alimento da vida intelectual. Porque o Geômetra não cuida das linhas ou figuras materiais de madeira ou de algum metal, mas apenas cuida delas como são em si mesmas. Ocorre que aquelas [figuras] não se encontram fora da matéria, mas o olho sensível olhas as figuras sensíveis de modo que as [figuras] mentais possam ser vistas pela mente. Assim também a mente vê as figuras mentais menos verdadeiras daquilo que vê o olho corporal as [figuras] sensíveis, mas tanto mais verdadeiras a mente vê aquelas figuras em si se separadas da alteridade da matéria. Mas o sentido exterior jamais as pode ver e nem tocar fora daquela alteridade, porque a figura recebe a alteridade da união daquela [figura sensível] à matéria. Por isso é necessário que uma seja diferente da outra, porque sendo feito um triângulo no solo e um outro semelhante e igual àquele em uma parede, sempre se encontra entre um e outro existir qualquer diferença. E semelhantemente, sendo feita uma pirâmide de pedra e outra semelhante e igual àquela de madeira, ou de algum outro metal, sempre existirá entre uma e outra qualquer diferença, e tal figura piramidal encontrar-se-á mais verdadeira em uma matéria do que em outra, mas em nenhuma matéria uma figura pode ser assim verdadeira e precisa que não possa ser [ainda] mais verdadeira e mais precisa. Então, o ver da mente vê as ditas figuras livres de qualquer alteridade variável, e a mente se encontra sem alteridade sensível, pois a mente é livre de toda matéria sensível e aquela é como [a] forma às figuras matemáticas. E vossa senhoria generosíssima dirá que as figuras são formas; a mente fará forma das formas, e as figuras na mente farão como em sua própria forma, mas serão sem alteridade. Então, cada coisa que a mente vê ela vê em si mesma, mas não aquelas coisas que a mente vê em alteridade sensível, e [vê] nessa mente. E aquela coisa que é abstrata e fora de qualquer alteridade não tem em si alto que a verdade, porque a verdade não é outra coisa que carência de alteridade. E se bem que a nossa mente não tem qualquer alteridade sensível, entretanto ela não falta de toda alteridade. Então a mente em que não falta de toda alteridade (ao menos da mental) vê as figuras absolvidas de qualquer alteridade, mas ela vê aquelas na verdade e não fora de si, porque vê aquelas mentalmente, e isso não pode ser feito fora dessa mente porque a coisa vista não é fora da mente. Assim como o sentido tocando sensivelmente não é fora do sentido, mas toca no sentido, a mente que vê em si mesma a coisa inalterável; dado que que a mente seja alterável, não vê a coisa inalterável na sua alterabilidade porque impedirá a alma que não pode separar o verdadeiro, mas aquilo que vê na sua alterabilidade, e a verdade é inalterabilidade. Então onde a mente vê, e cada coisa que vê, aqui está a verdade daquela e de todas as coisas que essa mente vê. Então a verdade, na qual a mente vê todas as coisas é forma da mente, e a mente é o lume da verdade, e por isso é a mente e nisso ela vê a si mesma e todas as coisas. Entretanto, ela não vê aquela verdade pela qual vê a si mesma e todas as coisas, mas apenas a vê porque é, mas que coisa seja. Assim como o nosso ver exterior não vê a claridade da luz solar, pela qual vê todas as coisas visíveis, mas ele experimenta ver coisa alguma sem a dita luz solar, e assim sabe porque ela é, mas não a coisa que seja, mas também a quantidade de luz, se não porque ela é tanta que excede a sua virtude. O mesmo é da [i.e., ocorre na] mente; nela a verdade da mente é como um espelho

concordo com eles e digo que, uma vez que o caminho de abordagem dos assuntos divinos só nos é aberto através de símbolos, podemos fazer um uso bastante adequado dos sinais matemáticos, devido às suas certezas incorruptíveis.” 
invisível, no qual a mente se vê a si mesma, e vê também todas as coisas visíveis por essa [mente], e aquela simplicidade especular é tanta que a excede em virtude e acuidade da mente; e quanto mais e mais se faz precisa e multiplica a virtude da mente, tanto mais é certo e mais claro que essa vê todas as coisas no espelho da verdade. E aquela virtude cresce pela especulação não de modo diverso que uma centelha que arde ardendo; e porque ela pega aquele crescimento de potência por esse lume da verdade mais e mais ela se põe em ato. Digo que aquela virtude é mandada para fora daquele lume de verdade, porque ela alcança aquele grau que aquele lume da verdade a possa fazer mais elevada. Esta coisa e muitas outras consideradas pelos ditos antigos Filósofos, perscrutadores da sabedoria ou filosofia, compreenderam (como é verdadeiro), não podem sem a dita Geometria corretamente filosofar, e determinaram aquela ser o verdadeiro princípio e fundamento dessa sabedoria ou filosofia. E por essa causa Platão, pai e mestre dos Filósofos, não queria que algum Estudante entrasse em sua escola se primeiro não era em Geometria bem ensinado. Assim fazia porque conhecia que nessa ciência geométrica cada outra ciência se encontra. Mas porque essa Geometria não pode estar por si e nem ser bem aprendia sem a sua irmã Aritmética, por isso segue que a Geometria junto com sua irmã Aritmética são o princípio e o fundamento da sabedoria. E encontrando-se naquele tempo Euclides Megarense $^{47}$, agudíssimo filósofo e em tal faculdade muito perspicaz entre outros, ela com seu maravilhoso engenho colocou ordenadamente em quinze livros estas duas disciplinas, Geometria e Aritmética (seja em operação como em especulação) com tanta e maravilhosa ordem quanto um homem possa imaginar, e de modo tal que daquele tempo até o presente, sem contradição, ele tem o principado em tal faculdade. E porque naquele tempo (por ordem comum desses Filósofos) a primeira coisa que se fazia ensinar a todos que se dedicavam à sabedoria era a Aritmética e a Geometria, ele quis intitular e chamar a dita obra de Obra dos princípios, quase querendo dizer Obra de princípios e fundamentos da Sabedoria ou Filosofia. E essa ordem antiga foi observada e mantida por longo tempo. Mas no presente, pelos modernos [ele] foi não apenas corrompido, mas também esquecido, de modo que as ditas duas ciências estão quase perdidas. E a prevaricação de tal ordem antiga (pelo tanto que posso considerar) aconteceu pelas causas ditas acima. Primeiro pela variação das línguas; qualquer um que desejar andar a fruir o nobre jardim da Sabedoria, no presente é necessário que busque entender a língua dos antigos Autores, que o colocarão na via correta (isso não era necessário antigamente, porque a língua era a deles própria), e que em torno disso se consuma parte do tempo que não apenas seria bastante para entender os ditos princípios, mas ainda a maior parte da coisa desejada. E depois que aprenderam a dita língua com grande fadiga e suor, e sem alguma parte dos princípios da coisa desejada, a maior parte como que cansados e abatidos (para abreviar o caminho e recuperar o tempo passado), abandonam a dita via antiga, e se dirigem per uma certa rua ou trilha modernamente encontrada. E se algum (de modo prudente) se coloca a estudar a Obra do dito muito sábio filósofo Euclides, encontrará aquela [obra] desregulada e depravada (como manifestamente se vê nas duas Traduções ${ }^{48}$ ). Mas como aquele adiciona nas definições quinta, sexta e oitava do quinto livro, imita o movimento dos nodos do dragão com

${ }^{47}$ Pisano e Capecchi (2016, p. 31) dizem que Tartaglia comete um equívoco, comum entre seus contemporâneos, de considerar que o autor dos Elementos teria sido Euclides de Mégara (séculos V-IV a.C.), discípulo de Sócrates que esteve presente quando de sua morte (Fédon, 59 b-c). 
trabalhosa falta de ar, e isso por razão de algumas interpolações de Campano ${ }^{49}$ (se são interpolações de Campano), que crendo elucidar tais definições (por sua pouca inteligência) deixou-as de tal modo confusas que o estudante de modo algum pode fazer um construto, e por isso é forçado a abandonar a empresa e dirigir-se para outra moderna rua ou trilha. E daqui talvez nasce que os nossos modernos não podem adicionar sinais aos antigos; e com razão deveriam por fazerem outra coisa, pois é fácil adicionar às coisas [já] encontradas. E pensando comigo a grandíssima utilidade destas duas disciplinas que conseguem aqueles que as sabem acomodar ao intelecto segundo débitos necessários, de modo que tornem a seu estado prístino e que a Obra do engenhosíssimo Euclides seja reconhecida, não somente quis fazer esta fadiga de ordená-la, integrá-la segundo as duas Traduções, mas também por comum utilidade traduzi-la do latim em vulgar [i.e., italiano] e esclarecê-la com exposições de tal modo claras (sobretudo as definições e outros passos obscuros) que qualquer engenho medíocre, sem noção de alguma outra ciência será capaz de entendê-la. Não que disso vossa Reverência se maravilhe, mas estas duas ciências ou disciplinas não têm necessidade de outra ciência quanto à sua essência, mas todas as outras têm necessidade delas, como no processo de fazer conhecer e ver, e não apenas as [artes] liberais, mas também todas as [artes] mecânicas. Depois pensando comigo a respeito de quem a minha útil fadiga eu deveria dedicar, certamente nenhuma [pessoa] mais digna de vossa R. (por muitíssimas razões) me veio à memória, por ser aquela não apenas amante e receptáculo de virtudes, mas um vaso de prudência, suma de generosidade, fonte de magnanimidade, lago de liberalidade, rio de conselho e mar de outro engenho, misto de humanidade a que todas as obras de virtude devem correr como a própria casa. E por não preterir aos termos de razão, aquela eu dedico, ofereço e doo; e não que aquela tenha tais duas ciências como vis, mas que (como acima está dito) antigamente foram reverenciadas, buscadas e celebradas por todos os muito perspicazes engenhos, mediante as quais não apenas chegaram à noção e cognição das coisas terrenas, a nós mortais necessárias, mas também por meio daqueles chegaram à cognição das [coisas] divinas. Isso testemunha o grande Filósofo Pitágoras, o qual tingiu toda a sua doutrina e teologia mediante os números. Pelo fato como escreve Salomão muito sábio: "Deus fez tudo com peso, número e medida" ${ }^{50}$, não obstante que se leia no Eclesiástico: "Quem mediu a altitude do céu, a largura da Terra e a profundidade do abismo?"51 Entretanto, tanta é a virtude destas duas ciências ou disciplinas, isto é, Aritmética e Geometria juntas com sua filha Perspectiva, que mediante elas nos conhecemos a virtude do compasso, e das proporções de quanto seja a rotundidade de toda a Terra e quanto seja seu diâmetro, e semelhantemente dos outros elementos. Pois como disse Aristóteles, o elemento superior é dez vezes quanto o seu [elemento] imediatamente inferior. Exemplo, a água é dez vezes quanto é todo o [elemento] terra; semelhantemente, o ar é dez vezes quanto é a água, e o fogo é mil vezes quanto é todo o [elemento] terra. E não

\footnotetext{
${ }^{48}$ Possivelmente, Tartaglia refere-se ao texto de Giovanni Campano, escrito no século XIII (que era, na verdade, uma reorganização do texto latino feito por Adelardo de Bath a partir de uma cópia árabe), e ao texto de Bartolomeo Zamberti, publicado em 1505 a partir de um códice grego. Cf. Barozzi (2016).

${ }^{49}$ Giovanni Campano ou Campano da Novara (1220-1296), matemático, astrônomo e médico, publicou a tradução dos Elementos (cf. nota anterior), que veio a ser editada por Luca Pacioli em 1509 sob o título Euclidis opera Campano interprete fidissimo tralata (Obra de Euclides traduzia fielmente por Campano).

${ }^{50}$ Livro da Sabedoria 11:20.

${ }^{51}$ Eclesiástico 1:3.
} 
obstante a grandeza destes corpos grandíssimos, se conhece na arte da Astronomia por ciência Geométrica, mediante a Perspectiva e por via do cálculo. Mas porque os escritores das letras (como escreve Isidorio no terceiro [livro] das Etimologias ${ }^{52}$ ) querem que a Aritmética seja a primeira das disciplinas matemáticas, por causa diss primeiramente em louvor daquela diremos algumas proposições. Coisa certa é que ela é nutridora e mãe dos Músicos (como afirma Boetio Severino ${ }^{53}$ e semelhantemente Franchin Gafforo em sua música ${ }^{54}$ ), pois sem os números e suas propriedades, proporções e proporcionalidades, não se pode conhecer claramente a consonância e dissonância de três ou mais vozes, mas com aquela se conhecer que uma quinta ou uma oitava fazem harmonia suavíssima e grandemente deleitam a audição dos ouvintes. E semelhantemente, com a dita ciência dos números sabemos que uma quarta [causa] grande dissonância e não pouco turba a audição. Esta, com suas regras calculatórias e virtude de seus números, dá o caminho a arte judiciária dita Astrologia, e semelhantemente à Piromancia, Hidromancia, Necromancia, Geomancia, Horóscopo, divinação [através de vísceras]; profecia e outras feitiçarias. E isto escreve o dito Isidoro e Cieco di Ascoli ${ }^{55}$, e semelhantemente Cornelio Agrippa no segundo [livro do] De occulta Philosophia. ${ }^{56}$ Ainda mais, sendo um dia perguntado ao divino Platão por qual causa o homem, entre outros animais irracionais, era chamado animal divino, ele respondeu porque o homem sabe numerar e as bestas não, quase querendo dizer que conhecer os números, como suas propriedades, era coisa divina, ou que com os números o homem vem a conhecer das coisas altas e peregrinas. Ainda por esta ciência de Aritmética,

${ }^{52}$ O livro III da obra Etymologiae (Etimologias) de Isidoro de Sevilha (560-636), entendida como a primeira enciclopédia da civilização ocidental, tem como título De mathematica (Da matemática) e apresenta as disciplinas matemáticas do quadrivium nesta ordem: aritmética, música, geometria e astronomia. Sobre a aritmética, Isidoro

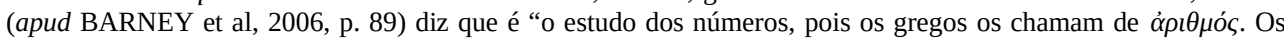
escritores da literatura secular teriam esta disciplina como a primeira dentre as disciplinas matemáticas, uma vez que esta disciplina não depende de nenhuma outra para a sua existência. No entanto, a música, a geometria e a astronomia, que seguem a aritmética, requerem o seu apoio para existirem e ocuparem o seu lugar."

${ }^{53}$ Anicius Manlius Torquatus Severinus Boethius (c. 480-524 ou 525), influente filósofo e teólogo cristão, é aqui referido pela tradição de sua obra De institutione Musica (Da instituição da música) que foi praticamente a única fonte para os estudos desta disciplina do Quadrivium medieval. Cf. Queiroz, 1999 apud Castanheira, 2009.

${ }^{54}$ Franchino Gaffurio (1451-1522), maestro di cappella e tratadista italiano, escrever as obras Theorica musicae (1492), Practica musicae (1496) e De harmonia musicorum instrumentorum opus (1518). Cf. Vittorelli, 2014.

${ }^{55}$ Cecco d'Ascoli ou Francesco degli Stabili (1257-1327) foi, assim como Isidoro de Sevilha, um enciclopedista. Em sua obra L'acerba (A amarga vida), escrita em versos, tem o capítulo III do Livro IV intitulado Metodi e valore delle scienze oculte (Métodos e valores das ciências ocultas) tratando, dentre outras, das artes da necromancia e quiromancia.

${ }^{56}$ Heinrich Cornelius Agrippa von Nettesheim (1486-1535), autor de De occulta Philosophia libri tres (Da filosofia oculta em três livros) que, como o título sugere, está organizado em três volumes: o primeiro trata da "magia natural”; o volume dois, da magia matemática ou celestial, e o volume três da magia cerimonial ou divina. Cf. Westphal, 2015. Anota-se que Tartaglia escreveu fora de universidades, nas quais não se ensinava disciplinas como a Pyromantia. Gregor Reisch (c. 1467-1525), sugere uma postura tradicional que se espera de um religioso, neste caso, um monge cartuxo. No índice de sua obra Margarita philosophica (Margarida filosófica), cuja primeira edição data 1503, ele descreve o sétimo livro a respeito de astronomia e diz (Reisch, 1503, p. 2r): "Astologie preaterca partes omnes percurrens. Genethliatos praecipue \& fatidicos prophetarum oraculis \& a sanctorum patrum sententis confutat: omnenque Superstitionis sobolen Necromantiam, Pyromantiam, Geomantiam artem Notoriam \& imaginum ritum \& execrationis pandit \& reptobat." ("Percorrendo todas as partes da astrologia, especialmente refuta astrólogos e videntes com oráculos dos profetas e sentenças dos padres santos, e expõe e reprova toda a raça de superstições: necromancia, piromancia, geomancia, arte notarial e ritos e maldições de imagens.”).

RBHM, Vol. 21, nº 42, pp. 81-145, 2021 
ou com as proporções de seus números, conhece-se na ciência de Geometria as quantidades comunicantes e incomunicantes, ou quero dizer, comensuráveis e não comensuráveis, e semelhantemente as racionais e irracionais, como do alto de nosso Euclides se manifesta. E semelhantemente, aquela com os números que nos ilumina e faz capaz de [entender] a quantidade de cada figura Geométrica, isto é, Triângulos, Quadrados, Tetrágonos longos, Pentágonos, Hexágonos, Rombos e Romboides, e todas outras figuras planas. E semelhantemente cada corpo sólido, seja regular como irregular, como são Pirâmides, Prisma ou Serráteis ${ }^{57}$, Esferas, Cones, cilindro ou Colunas, Cubos, Octógonos, Dodecaedro, Icosaedro como todas as suas propriedades e proporções. E como também geometricamente descreve e forma o nosso egrégio Autor Euclides em quinze livros: dos quais onze são de Geometria, isto é, o primeiro, o segundo, o terceiro, o quarto, o sexto, o décimo, o undécimo, o duodécimo, o décimo terceiro, o décimo quarto e o décimo quinto, e três são de Aritmética, isto é, o sétimo, o oitavo e o nono. O quinto a todos esses é comum, o qual trata da proporção e proporcionalidade: proporção e proporcionalidade assim se espera em número como em medida. E tanta é a utilidade, além da suavidade e doçura do estudo que se encontra nas contemplações matemáticas, plenas de certeza, que Arquimedes siracusano com o estudo daquelas com seus engenhos mecânicos defendeu por um tempo a Cidade de Siracusa contra o ímpeto de Marco Marcello, Consul Romano, e por isso colocou seu nome na imortalidade. Por virtude destas [matemáticas], Dédalo peritíssimo fabricou o nomeado Labirinto do Minotauro. Por meio delas, fez vários e diversos modelos: fabricou pontes com arco, quase impossíveis à natureza. Ainda que com o intelecto bem considera todas as coisas de máquinas antigas e modernas, e instrumentos bélicos, sejam ofensivos como defensivos, como são bastiões, proteções, refúgios, trabucos, catapultas, escorpiões, balistas, aríetes, tartarugas e helépolis ${ }^{58}$, como demonstra Vitrúvio no décimo [livro do $D a$ arquitetura], sempre com força de números e medidas as suas proporções se encontram formadas e fabricadas. Das novas invenções por mim encontradas sobre as modernas máquinas que causam tormentos (ditas pelo vulgo, artilharia) não quero repetir: por ter em outro local dito e em parte publicado. ${ }^{59}$ Basta somente dizer que por conselho destas [matemáticas] (sem alguma prática em tal exercício) eu encontrei a maior parte. Destas mesmas disciplinas brota e nasce a ciência dos pesos, como abertamente Iordano ${ }^{60}$ naquele De ponderibus, por meio da qual ciência Aristóteles em suas questões mecânicas considera a causa de toda miraculosa invenção mecânica. De quanta ajuda e base são as ditas duas

\footnotetext{
${ }^{57}$ Prismas de base triangular.

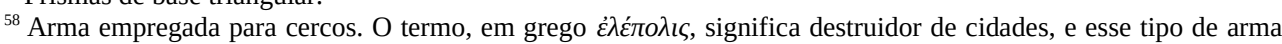
foi utilizada por Demetrius Poliorcetes, general de Alexandre, nos ataques contra Salamina do Chipre e no cerco de Rodes em 306 a.C.

${ }^{59}$ Ele se refere ao livro Inventione novamente trovata (Invenção novamente encontrada), publicada em 1537, primeira edição do La nova scientia (A nova ciência).

${ }^{60}$ Jordanus de Nemore ou Jordanus Nemorarius (séc. XIII) reuniu na obra Liber de ponderibus os axiomas e demonstrações tratando da "ciência dos pesos", isto é, da mecânica, já apresentados em suas obras anteriores Elementa super demonstrationem ponderum (Elementos sobre demonstração dos pesos) e Liber de canonio (Livro da viga). Moody (1952, p. 170) afirma que alguns dos teoremas deste livro tem relação com as questões existentes em uma obra aristotélica não preservada tratando de problemas mecânicos. "Ainda que nenhuma tradução medieval deste trabalho de Aristóteles seja atualmente conhecida, a presença desses teoremas no De ratione ponderis dá uma indicação de que algumas partes dos Problemas Mecânicos eram conhecidas fosse numa tradução direta ou por intermédio de um canal seguro, no século XIII.”
} 
ciências ou disciplinas à Arquitetura, Vitrúvio Pollione o faz manifesto em seu proêmio. Ainda que quem bem considere e olhe a ciência Perspectiva, sem dúvida nada encontraria se a Geometria como mãe não acomodasse. Assim se manifesta o nosso dito Euclides em sua Perspectiva, e semelhantemente o Arcebispo Giovanni Cantuariense ${ }^{61}$, mas mais abundantemente Viteleo ${ }^{62}$, o qual aprova cada proposição sua, e demonstra com proposições euclidianas. O que diremos da Cosmografia e Geografia: não nos demonstra Ptolomeu e todos os outros excelentíssimos Cosmógrafos e Geógrafos quanto são necessárias essas duas ciências ou disciplinas? Quando de todo o universo, devidamente proporcionando os seus graus de longitude e latitude, [elas] fazem caber em um pequeno mapa todas as famosas Províncias, Cidades, Castelos, Montanhas, Rios, Ilhas e outros sítios marinhos e mediterrâneos (como mais vezes junto com V. R. sobre o seu mapa de navegação o tenha me mostrado e visto, e semelhantemente sobre o seu Globo Germânico). E aquela saiba que não por outra causa ao presente é penúria dos bons e excelentes Astrônomos, salvo por defeito e ignorância das ditas duas ciências ou disciplinas. Porque bem entender o Almagesto de Ptolomeu e semelhantemente Giovani de Monte Regio ${ }^{63}$ sem instruções Euclidianas, não se pode contar. Mais forte, Bartolo da Sassoferrato, na sua Teberina $^{64}$, usando suas figuras geométricas, demonstra expressamente a Geometria ser necessária ao direito. Além disso, a guia e escolta de nossa salvação, a Sagrada Teologia, não demonstra abertamente o R. Cardeal Nicolo de Cusa, na penúltima parte de sua Obra, não podem ser comunicadas ao nosso intelecto sem Geometria? Essa parte é intitulada Complementum Theologicum figuratum in complementis mathematicis. Ainda mais, ele tem tanta necessidade desta disciplina e ciência Geométrica que não somente os homens mortais, nas suas coisas comensuráveis usam aquela (como acima muitas vezes é dito), mas ainda o grande Deus, o qual é medida de todas as coisas, ao formar as partes do corpo humano não se governa sem aquela [ciência], com a qual ainda estes Compositores de imagens e pintores excelentes se conforma, a cada membro usando o seu compasso. Por isso também os peritíssimos Arquitetos (como nos manifesta Vitrúvio Pollione no primeiro capítulo do seu terceiro livro) buscam com toda diligência de proporcionar ao Templo e a outros [edifícios] públicos e privados à semelhança do dito corpo humano, por ser esse (como é dito) com devidas medidas fabricado pelo sumo Arquiteto. Ainda se conhece a nobreza, excelência e altura da dita Geometria por sua grande fama e nome daqueles que

\footnotetext{
${ }^{61}$ John Peckham (1230-1292) publicou a obra Perspectiva communis (Perspectiva comum) que, de acordo com Lindberg (1965) tem uma forma euclidiana, em que cada proposição consiste no conjunto de um enunciado e uma demonstração. Há uma influência significativa, no entanto, das ideias de Roger Bacon nos escritos de Peckham nos enunciados que não são realmente demonstrados, mas explicados a partir de um acúmulo de evidências.

${ }^{62}$ Erazm Ciołek ou Vitello Thuringopolonis (c. 1270-1285) menciona nominalmente apenas duas fontes em sua obra Perspectiva (Perspectiva): Euclides e Apolônio. Unguru (1977) identifica, no entanto, que seu tratado está baseado em leituras de Alhazen (Abu Ali al-Hasan Ibn Al-Haitham), Campano da Novara, além das adições de

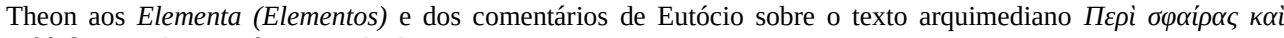

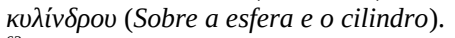

${ }^{63}$ Johannes Müller von Königsberg ou Regiomontanus (1436-1476) escreveu obras sobre todas as áreas da matemática de seu tempo, incluindo a álgebra em desenvolvimento no cenário europeu.

${ }^{64}$ Bartolo de Sassoferrato (1314-1357), na introdução de seu tratado a respeito de leis chamado De fluminibus seu Tyberiadis (Dos rios ou Tiberíade), menciona que a inspiração lhe foi dada em um sonho quando uma figura lhe ordenou "Escreva o que começou a pensar e desde que exista necessidade de uma ilustração, ofereça diagramas matemáticos (com régua e compasso).” Cf. Plessis (1999, p. 35).
} 
deram obras a enfeitar e estudar dita ciência, como foram Mercúrio Trismegisto filósofo, Sacerdote e Rei do Egito ${ }^{65}$, semelhantemente Pitágoras, Platão, Plotino, Aristóteles, Averrois, Hipócrates, o nosso Euclides, Ptolomeu, Arquimedes, Apolonio Pergeo, Iordano, Vitrúvio Arquiteto e muitos outros, os quais deixo por brevidade para não entediar mais o sentido da audição de V. R., parecendo-me que pelas coisas ditas e alegadas ela [i.e., V. R.] deva ser não apenas ser informada e advertida que as ditas disciplinas não são fábulas nem outras [coisas] ridículas e falsas historinhas, e nem semelhantemente invenções poéticas não críveis, que de vento e fumaça nossas orelhas sofrem. Mas é totalmente certo (como é verdadeiro) que não apenas são verdadeiras, mas veríssimas (como no princípio foi dito) e no primeiro grau de certeza, como ainda afirma Aristóteles no primeiro livro dos [Analíticos] posteriores, texto 25, e semelhantemente Averrois sobre o segundo [livro] da Metafísica. Por isso não duvido que vossa R. terá tal coisa grata, porque sou certo que aquela [i.e., V. R.] com seu engenho admirável e discurso natural nas coisas acidentais conseguirá tirar grandíssimos construtos, aos quais com humilde e devida reverência grandemente eu peço, rezando ao Deus onipotente que lhe agrade restituir a sua prístina saúde e que a faça crescer, e conservar com todos os seus próximos benévolos, e segundo cada um de seus bons desejos. Adeus.

\title{
3.2. Invenção de Niccolo Tartaglia Bresciano intitulada Ciência nova
}

\author{
I N V E N Ç Ã O D E N I C C O L O \\ Tartaglia Bresciano intitulada Ciência nova dividida \\ em 5 livros: no primeiro dos quais se demonstra teo- \\ ricamente a natureza e os efeitos de corpos \\ igualmente pesados, em seus dois movimentos \\ contrários que neles podem ocorrer \\ e de seus efeitos contrários
}

No segundo (geometricamente) se prova e demonstra a qualidade, semelhança e proporcionalidade de seus trajetos segundo vários modos segundo os quais podem ser ejetados ou empurrados violentamente através de ar, e semelhantemente suas distâncias.

No terceiro se ensina uma nova prática de medir com o olhar as alturas e as distâncias diagonais e horizontais das coisas aparentes, e adiciona-se ainda a teoria, isto é, a razão e causa de tal operar.

No quarto, se dará a proporção de ordem do subir [e] descer que em cada peça de artilharia nos seus tiros, levantando ou abaixando sobre o plano do horizonte, e semelhantemente em cada morteiro. Ainda se ensinará o modo de encontrar todas as ditas variações ou quantidade de tiros de cada peça de artilharia ou morteiro mediante a noção de tiro apenas.

${ }^{65}$ Hermes Trismegisto (vida e obras estimadas entre 2500 a.C e 1500 a.C), filósofo e legislador egípcio a quem são atribuídas as ideias registradas nos livros reunidos na coletânea Corpus Hermeticum no início da era cristã e que, divulgados na Europa, influenciaram autores do neoplatonismo renascentista. 
Ainda se mostrará o modo como se deva governar um bombardeiro [i.e., artilheiro] quando deseja de bater ou percutir em qualquer lugar aparente.

Além disso, se ensinará ainda o modo como se deva governar o dito bombardeiro [i.e., artilheiro] quando fosse colocada proteção em frente ao local onde percutir, querendo então percutir no mesmo lugar por outra via ou elevação, mesmo que não veja tal lugar.

E ainda se dará o modo de saber percutir continuamente de noite um lugar escolhido um dia antes.

E no quinto livro se declarará (segundo a autoridade de muitos Excelentíssimos [filósofos] Naturais) a natureza e a origem de diversos tipos de colas, óleos, águas destiladas, [e] ainda de diversos minerais e não minerais simples produzidos pela natureza e fabricados pela arte, [e] ainda se manifestará algumas particulares propriedades deles a respeito da arte de fogos. E semelhantemente se elucidará quais são aquelas matérias que convêm e que estão de acordo, e quais são aquelas que não convêm e que não estão de acordo, para arder conjuntamente, e consequentemente se dará o modo de compor várias e diversas espécies de fogos não apenas utilíssimas para defesa de qualquer terra fortificada, mas também a outras ocorrências muito apropriadas.

\author{
A O I L U S T RÍS S I M O E M U I T O I M B A T ÍVE L S E N H OR \\ Francesco Maria Feltrense dalla Rovere ${ }^{66}$, Duque Excelentíssimo de Urbino e \\ de Sora, Conde de Montefeltro e de Durante, Senhor de Senegalia \\ e de Pesaro, Prefeito de Roma e do Nobre Senado \\ Veneziano, Digníssimo General Capitão
}

\title{
EPÍSTOLA.
}

HABITANDO EM VERONA NO ANO DE 1531, Ilustríssimo S. Duque, me foi perguntado por um amigo íntimo e cordial, peritíssimo bombardeiro em Castelvecchio (homem idoso e repleto de muitas virtudes), do modo de montar uma peça de artilharia de modo a atirar mais longe. $\mathrm{E}$ bem que em tal arte eu não tivesse prática alguma (porque [é] verdade, Excelente Duque) e que jamais descarreguei artilharia, arcabuz, bombarda e canhão de mão, não obstante (e desejando servir o amigo) prometi a ele dar em pouco tempo resposta decidida. E depois que tive bem mastigada e ruminada tal matéria, expus e demonstrei a ele com razões naturais e geométricas que necessitava que a boca de tal peça [de artilharia] estivesse elevada de modo que olhasse retamente a 45 graus sobre a linha do

${ }^{66}$ Francisco Maria I Della Rovere (1490-1538) foi comandante militar e nobre veronense e, na época da publicação de Nova Scientia, foi o responsável por organizar o reforço das forças de defesa contra a coligação do Império Otomano com o exército francês do Rei Francisco I (https://www.treccani.it/enciclopedia/francesco-maria-i-dellarovere-duca-di-urbino_\%28Dizionario-Biografico\%29/). 
horizonte, e que para fazer tal coisa de modo veloz requereria ter um esquadro [feito] de algum metal ou madeira sólida que tenha um quadrante com uma linha perpendicular [de chumbo] como abaixo aparece no desenho, e colocando então uma parte da perna maior daquela (isto é, a parte be) na alma ou boca da peça colocada retamente no vazio do cano, levantando depois tanto para cima a dita peça quanto a linha perpendicular hd segue o lado curvo egf (do quadrante) em duas partes iguais (isto é, no ponto $g$ ). Então se dirá que a dita peça olhará retamente a 45 graus acima do horizonte. Pois (Senhor claríssimo) o lado curvo egf do quadrante (segundo os astrônomos)

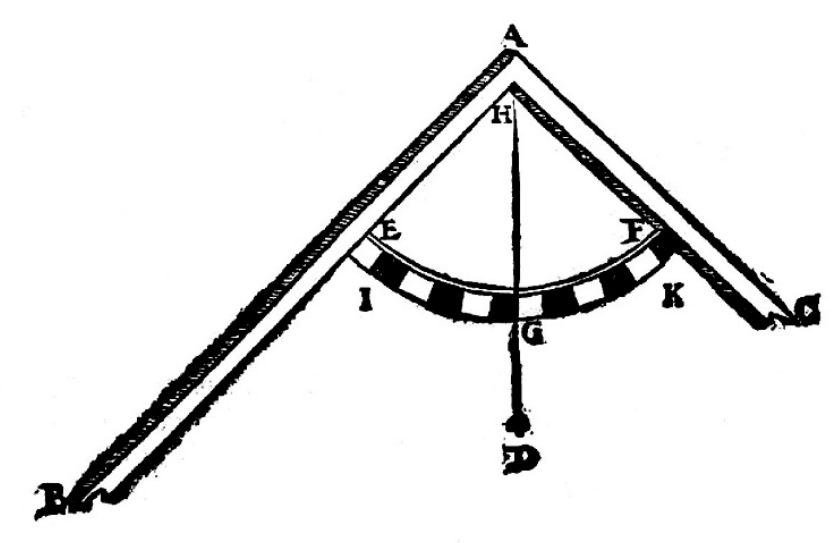

se divide em 90 partes iguais, e cada uma dessas chamamos grau, mas a metade daquele (isto é, $g$ f) vem a ser 45 graus. Mas para ter acordo com aquilo que se tem a dizer dividimos em 12 partes iguais de modo que vossa Ilustríssima D. S. veja em figura aquilo que acima pintamos como palavras, e abaixo desenhamos a peça com o esquadro na boca montado segundo o propósito por nós concluído ao dito nosso amigo. Essa conclusão a ele parecia ter qualquer consonância, mas a respeito dela duvidava porque a ele parecia que tal peça olhasse muito alto. Isso ocorria porque ele não era capaz de entender nossas razoes, pois não era ensinado em Matemáticas, mas, não obstante, com alguns experimentos particulares no fim se verificou que assim era. 
Peça elevada a 45 graus sobre o horizonte.

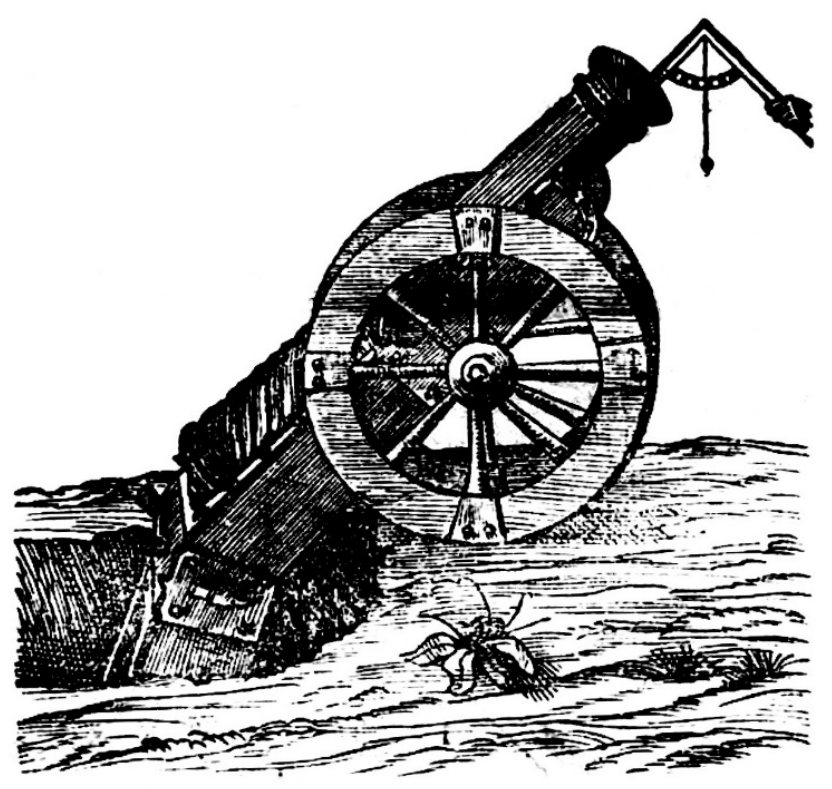

Mas no ano de 1532, sendo prefeito em Verona o Magnífico senhor Leonardo Iustinano, um capitão dos bombardeiros, amicíssimo daquele nosso amigo, veio em concorrência [i.e., desafiou] com um outro (no presente, chefe dos bombardeiros de Pádua), e um dia ocorreu que entre eles foi proposto o mesmo que a nós propôs aquele nosso amigo, isto é, a que marca se deveria colocar uma peça de artilharia para que fizesse o maior tiro que se pudesse fazer sobre um plano. Aquele amigo daquele nosso amigo concluiu com um esquadro em mãos o mesmo que por nós foi alcançado, isto é, como acima dissemos e [como] desenhado em figura.

O outro disse que muito mais atiraria a dois pontos [se] baixada tal esquadro (o qual era dividido em 12 partes) como abaixo aparece em desenho. 


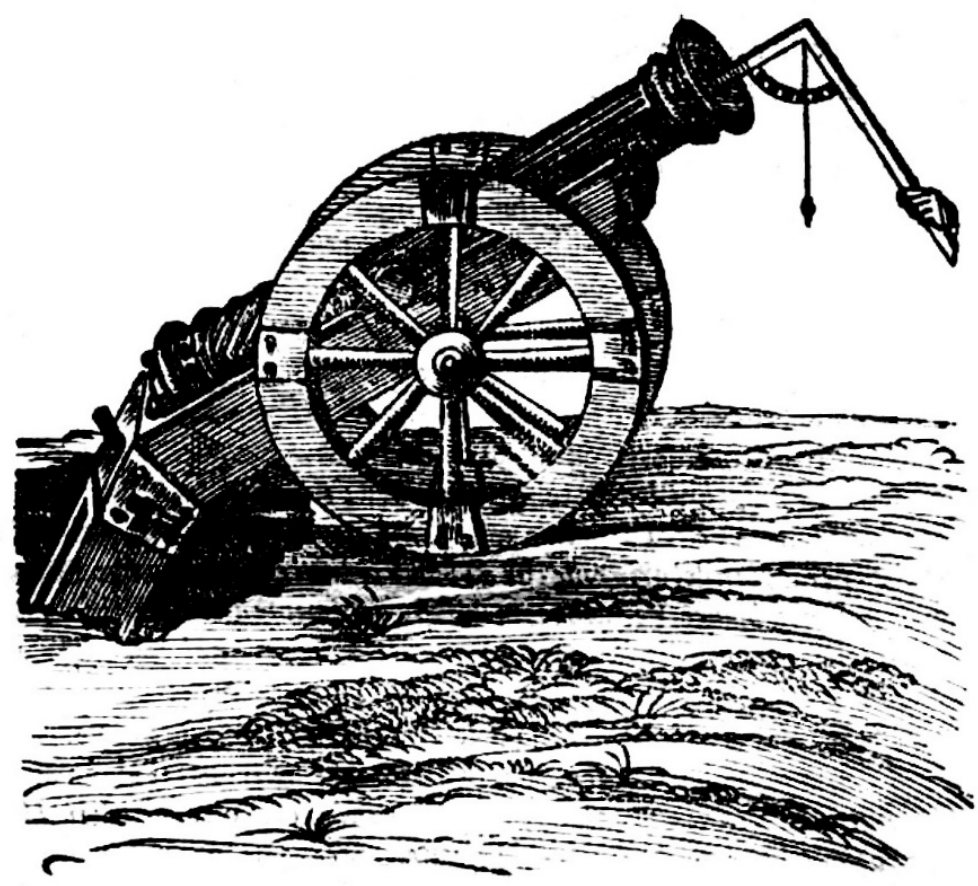

E acima deste foi colocada uma certa quantidade de dinheiro, e finalmente chegamos à experiência. Uma colubrina ${ }^{67}$ de 20 [libras] foi trazida ao campo de Santa Lucia, e cada um deles atirou segundo a proposta sem nenhuma vantagem de pólvora ou de bala. Então, aquele que atirou segundo nossa determinação atirou longe (segundo que foi referido) 1972 pertiche, cada uma tendo seis pés alla veronesa ${ }^{68}$, e o outro atirou longe apenas 1872 pertiche. Todos os bombardeiros e outros verificaram a nossa determinação, embora antes desta experiência estavam em dúvida e a maior parte tinha opinião contrária, parecendolhes que tal peça olhasse muito alto. Mas mais importante quero que vossa Preclaríssima Senhoria saiba que de três coisas [a seguir] é forçoso que seja uma [verdadeira]: ou que os medidores erraram ao medir; ou que a mim não foi referida a verdade, ou que o segundo foi mais diligentemente carregado do que o primeiro. Porque a razão demonstra que segundo (isto é, aquele que atirou dois pontos mais baixo) atirou enquanto mais de dever a proporção do primeiro, ou que o primeiro atirou enquanto menos daquele que devia puxar à

\footnotetext{
${ }^{67}$ Canhão medieval de barril relativamente longo e construção leve capaz de disparar projéteis de 3,6 kg a 7,3 kg a longas distâncias. Foi adaptado ao uso no campo pelos franceses em meados do século XV e ao uso naval pelos ingleses em finais do século XVI. (https://www.sapere.it/enciclopedia/colubrina+(militaria).html).

${ }^{68}$ Uma pertica Veronese, unidade correspondente à francesa toise, definida como seis pés, como dito na Geometria pratica (Geometria prática) de Lodovico Perini (1773, p. 51-52) correspondia a aproximadamente dois metros, o que leva a estimar 1972 pertiche como aproximadamente 4 quilômetros.
} 
proporção do segundo, como no quarto livro (onde trataremos da proporção dos tiros) em breve aquela [i.e., Preclaríssima Senhoria] poderá conhecer e ver. E saiba, vossa magnanimidade, que por ser a hora em tal matéria sabido deliberei querer tentar um pouco mais. E comecei (não sem razão) e investigar as espécies de movimentos que em um corpo grave pudesse acontecer, e então encontrei esses de dois tipos, isto é, natural e violento, e encontrei serem totalmente em acidentes contrários mediante os seus efeitos contrários. Semelhantemente, encontrei com razão evidente ao intelecto ser impossível um corpo grave mover-se de movimentos natural e violento misturados. Depois investiguei com razões geométricas demonstrativas a qualidade de trânsitos, ou movimentos violentos dos ditos corpos graves segundo os vários modos que podem ser ejetados ou jogados violentamente pelo ar. Além disso me certifiquei com razões geométricas demonstrativas o modo em que todos os tiros de todo o tipo de artilharias, sejam grandes como pequenas, igualmente elevadas sobre o plano do horizonte ou igualmente oblíquas ou ainda no plano do horizonte, são entre si semelhantes e consequentemente proporcionais, e semelhantemente a sua distância [i.e., a distância alcançada]. Depois, conheci com razão natural o modo em que a distância do acima dito tiro elevado a 45 graus sobre o horizonte era por volta de dez vezes o trânsito de um tiro reto feito no plano do horizonte, que por bombardeiros é dito atirar de ponto em branco. Com essa evidência, Magnânimo Duque, encontrei com razões geométricas e algébricas o modo que uma bala atirada em torno dos ditos 45 graus sobre o horizonte alcança por volta de quatro vezes por linha reta mais do que aquela que vai sendo atirada no plano do horizonte, o que por bombardeiros é dito (como eu disse) atirar de ponto em branco. Por isso se manifesta o modo de uma bala atirada por uma mesma artilharia vai mais por linha reta desse modo do que por outro, e consequentemente faz mais efeito. Além disso, Senhor Ilustríssimo, calculando encontrei a proporção de subir e descer que faz cada peça de artilharia (nos seus tiros), levantando ou abaixando sobre o plano do horizonte, e semelhantemente encontrei o modo de saber encontrar a variedade dos ditos tiros em cada peça, seja grande como pequena, mediante a noção de um tiro apenas (considerando que seja sempre igualmente carregado). Depois investiguei a proporção e ordens de tiros do morteiro, e semelhantemente encontrei o modo de saber investigar brevemente a variedade de ditos tiros por meio de um tiro apenas. Além disso, com razões evidentíssimas conheci o modo que uma peça de artilharia podia por diversas vias (ou elevações) percutir o mesmo local, e encontrei o modo de mandar tal coisa (acontecendo) a execução (coisa não ouvida nem cogitada por algum outro antigo nem moderno). Mas depois considerei (Senhor Magnífico) que todas essas coisas eram de pouca utilidade a um bombardeiro quando a distância do local onde lhe ocorresse de atingir não the fosse conhecida. Por exemplo, ocorrendo-lhe atirar em um local aparente cuja distância lhe fosse oculta, o que lhe valeria (ó Magnânimo Duque) nesse caso que a sua peça atirasse a partir de uma elevação de 1356 passos e a outra 1468 passos, e a tal outra 1574? E assim discorrendo de grau em grau, certamente ele nada faria de útil, porque não sabendo a distância menos saberá a que ponto ou elevação deva elevar sua peça de artilharia para que percuta o desejado local. Segue-se serem duas as principais partes necessárias a um real bombardeiro (querendo atirar com razão e não ao acaso), das quais sem uma e nem a outra quase nada faz de útil (digo de tiros à distância). A primeira é que grosso modo saiba conhecer e investigar (com a visão) a distância do local que lhe ocorre atingir. A segunda é 
que saiba a quantidade de tiros da sua artilharia segundo as suas várias elevações. Sabendo tais coisas não errará muito em seus tiros, mas faltando-lhe uma daquelas [i.e., dessas] não pode atirar (em qualquer conta) com razão, mas somente com discrição [i.e., intuição], e se por acaso percute no primeiro tiro o local, ou perto do local onde deseja, fará mais por sorte do que por ciência (digo ainda de tiros à distância). Isso porque (Senhor Ilustríssimo) encontrei um novo modo de investigar brevemente as alturas, profundidades, larguras, distâncias "hipotenusais" ou diagonais, e ainda as horizontais das coisas aparentes, não em tudo como coisa nova. Porque verdadeiramente Euclides, na sua perspectiva, breve e teoricamente em parte as ensina, e semelhantemente Giovanne Stoflerino ${ }^{69}$, Orontio ${ }^{70}$, Pietro Lombardo ${ }^{71}$ e muitos outros deram a tal matéria norma aqui com o Sol, ali com um espelho, aqui com um quadrante, ali com o astrolábio, aqui com duas varas, ali com um bastão (intitulado cajado de Jacó ${ }^{72}$ ), e em muitos outros vários modos. Mas eu digo (Senhor Claríssimo) que encontrei um modo novo veloz, rápido e fácil de entender a qualquer um (e a menos erros sujeito de qualquer outro) que investiga as ditas distâncias, o qual por nenhum outro foi colocado, especialmente considerando as distâncias diagonais ou diametrais e ainda das horizontais, as quais em verdade são as mais necessárias a um bombardeiro do que os outros tipos de dimensões, porque a ele é muito necessário saber a altura de uma coisa perpendicularmente elevada sobre o horizonte, ainda a profundidade de uma coisa profunda e a largura de uma coisa larga. Mas somente as ditas distâncias diagonais e horizontais lhe são muito a propósito, como no quarto livro (a vossa Ilustríssima Senhoria) se fará manifesto. Além disso, por curiosidade me coloquei a discorrer a respeito dos vários modos observados por nossos antigos [filósofos] Naturais e também por modernos na composição de fogos, e entre os [filósofos] naturais investiguei a natureza das gomas, betumes, gorduras, óleos, sais, águas destiladas e outros minerais simples, e também minerais não produzidos pela natureza, mas fabricados pela arte, que compõem aqueles [i.e. gomas etc.]. Consequentemente, encontrei o modo de compor muitas outras variadas e diversas espécies de fogos não apenas para defesa utilíssima de cada terra fortificada, mas ainda em muitas outras ocorrências muito a propósito. Por essas coisas, eu tinha deliberado de regrar a arte dos bombardeiros e fazê-la mais perfeita do que fosse possível fazer (mediante algumas experiências particulares), porque em verdade (como diz Aristóteles no sétimo [livro] da Física, texto vigésimo), da experiência de particulares tiramos a ciência universal. ${ }^{73}$ Mas depois, pensando comigo um dia, me

${ }^{69}$ Johannes Stöffler (1452-1531) publicou, em 1524, a obra Elucidatio fabricae ususque astrolabii (Explicação da fabricação e uso do astrolábio), em que dá orientações detalhadas sobre o uso do astrolábio para observações astronômicas e para medição das distâncias diagonais.

${ }^{70}$ Oronce Finé ou Orôncio Fineu (1494-1555) escreveu Protomathesis (Primeiras ciências), publicada em 1530, cujo quarto capítulo tem o título De solaribus horologiis \& quadrantibus libri com informações sobre relógios de sol, quadrantes e astrolábios.

${ }^{71}$ Pietro Lombardo (1435-1515): arquiteto e escultor responsável, dentre outras pela igreja de Santa Maria dei Miracoli e pela tumba de Dante Alighieri.

${ }^{72} \mathrm{O}$ instrumento de medição denominado cajado de Jacó foi descrito pelo matemático judeu-francês Levi ben Gerson em seu livro Sefer Milhamot Ha-Shem (As Guerras do Senhor).. Também conhecido como bastão cruzado ou balestilha, trata-se de uma haste com uma travessa perpendicular, dotada de marcações de comprimento (https://stringfixer.com/pt/Jacob's_Staff, acesso em 10 jul. 2021).

${ }^{73}$ Possivelmente Tartaglia refere-se a Aristóteles 247b1-7, que é assim explicado por Simplício: "Sempre que a percepção alcança o particular, nesse momento, então, o intelecto conhece realmente os pormenores através do 
pareceu coisa criticável, infame, cruel e digna de não pouca punição em frente a Deus e aos homens querer estudar e aperfeiçoar tal exercício danoso ao próximo, ou melhor, destruidor da espécie humana, principalmente de Cristãos em suas guerras contínuas. Por isso não apenas parei totalmente o estudo de tal matéria e comecei a estudar outras [matérias], mas rasguei e queimei todas os cálculos e escritura por mim feitos que falasse de tal matéria. E muito me doeu e me envergonhei do tempo que me gastei naquelas particularidades, que na memória me restam (contra minha vontade) inscritas. Nunca quis falar delas a qualquer um, nem por amizade nem por prêmio (não importando quanto fosse pedido) porque ensiná-las me parecia fazer naufrágio e grande erro. Mas agora vendo o lobo ${ }^{74}$ desejando entrar no nosso rebanho e, dado que cada pastor concorda com a defesa, não me parece lícito neste momento manter tais coisas ocultas. Então, deliberei de publicar em parte em escrito e em parte a viva voz a cada cristão, de modo que cada um saiba melhor como atacar e como se defender daquele [lobo]. E muito me arrependo, vendo a necessidade de tal estudo, de tê-lo abandonado, porque estou certo de que tendo seguido até hoje eu teria encontrado coisas de maior valor, como espero ainda de encontrar. Mas porque o presente é certo (e ao tempo breve) e o futuro é duvidoso, quero mostrar primeiramente aquilo que no presente tenho, e para mandar tal coisa a sua execução compus em imprensa esta presente obrinha, a qual, como cada rio naturalmente busca de aproximar-se e unir-se com o mar, assim essa (conhecendo vossa Ilustríssima D. S. ser a soma entre os mortais de toda virtude bélica) busca de unir-se com essa amplitude [i.e., vossa Ilustríssima]. Mas como o abundante mar, o qual não tem necessidade de água e não desdenha receber um pequeno rio, assim espero que vossa D. S. não desdenhará de aceitá-la, de modo que os peritíssimos bombardeiros de nosso Ilustríssimo Domínio sujeitos a vossa Sublimidade, além de seu ótimo engenho prático, sejam instruídos de melhores razões e aptos a executar as ordens daquela [i.e., vossa D. S.]. E se nestes três livros não satisfaço plenamente vossa Excelentíssima Senhoria junto com os seus ditos peritíssimos bombardeiros, espero que em breve com a prática dos livros quarto e quinto, não ainda em estampa (por diversos motivos), mas já bem escritos, ou em viva voz, eu possa satisfazer em parte vossa Sublimidade junto com aqueles, a cuja graça como ínfimo e humilíssimo Servidor, devotamente eu me recomendo.

Terminada em Veneza nas casas novas de São Salvador, no dia 20 de Dezembro, 1537.

De vossa Ilustríssima D. S. Ínfimo Servidor.

Niccolò Tartaglia Bresciano

universal. 'Pois um ser humano individual também é um ser humano', como o próprio Aristóteles afirmou noutro lugar. [...] o conhecimento do universal não está ao mesmo nível do particular; em vez disso, o particular é conhecido 'através do conhecimento universal', porque o particular é englobado pelo universal.” Cf. Simplicius (1998, p. 55).

${ }^{74} \mathrm{O}$ "lobo" em questão era o imperador turco Suleiman (1520-1566) que entre 1526 e 1532 comandou ataques na (atual) fronteira da Áustria e Hungria. Tartaglia fala dele na carta-prefácio do Quesiti et inventioni diverse (Questões e invenções diversas) no seguinte modo (Tartaglia, 1554, fol. 4r): "Ma piu sentendo io l'anno MDXXXVII. con quanto gran preparamente si moueva Soliman Imperator de Turchi, per infestare la nostra Christiana Religone, Compossi con gran celerità sopra à tal materia uma operina, \& quella publicai." ("Mas depois vendo eu o ano de 1532, no qual se movia com grande preparação Suleiman, Imperador dos Turcos, para infestar nossa Religião Cristã, compus com grande pressa sobre tal matéria uma pequena obra, e publiquei-a.”).

RBHM, Vol. 21, n 42 , pp. 81-145, 2021 


\subsection{Tratado Geral de números e medidas}

\section{A P R IMEIR A P A R TE D O TR A T A D O GER A L DE NÚMEROS E MEDIDAS DE NICCOLÒ TARTAGLIA,} NA QUAL EM DEZES S T E

L IVROS SE DECLAR A TODOS OS A TOS OPER A T I V S, PRÁ T ICAS E REGRAS NECESS ÁRIAS N Ã O A P E N S em toda arte comercial e mercantil, mas também em toda e qualquer arte, ciência ou disciplina onde intervém o cálculo.

Em Veneza, por Curtio Trioano dei Navò. 1556

\section{A O M U I T O N O B R E E E GRÉGIO S E N H OR O SENHOR RICARDO VENTVORTH ${ }^{75}$, GENTIL-HOMEM INGLESS, PADRINHO E MUITO HONRADO.}

Os antigos sábios, honorável senhor compadre, como escreve Ptolomeu no princípio do Almagesto $^{76}$, dividiram a sabedoria em duas partes, a primeira da qual do dito Ptolomeu é dita especulação e a outra é chamada operação. Essas duas partes comumente ainda uma é dita teórica ou especulação, e outra [é dita] prática, ativa ou operativa, e entre essas duas partes, como afirma Ptolomeu, existe não pouca diferença. A causa é que tendem a diversos fins, porque o fim da ciência especulativa, como diz Aristóteles no segundo [livro] da Metafísica $^{77}$, não é outro que a verdade, e [o fim] da operação ou prática [é] a obra completa. E se bem que a especulação, por ser investigadora das causas próximas e aumentadora da ciência, seja muito mais nobre do que a operação ou prática operativa, a qual apenas espera saber executar com diligência e conduzir prontamente ao fim ou a efeito de todas as coisas já encontradas especulativamente, notificadas e reguladamente colocadas

\footnotetext{
${ }^{75}$ Pisano e Capecchi (2016) afirmam que Richard Wentworth era um nobre inglês, pupilo de Tartaglia em um período em que esteve em Veneza. Um manuscrito em italiano em que Tartaglia é amplamente citado está arquivado na Oxford Bodleian Library, Ms 584, UK, e a autoria seria deste mesmo Richard Wentworth.

76 "Pois mesmo que a filosofia prática, antes de ser prática, acabe por se revelar teórica, no entanto pode-se ver que existe uma grande diferença entre as duas: em primeiro lugar, é possível que muitas pessoas possuam algumas das virtudes morais mesmo sem serem ensinadas, ao passo que é impossível alcançar a compreensão teórica do universo sem instrução; além disso, no primeiro caso [filosofia prática] alguém obtém mais proveito da prática contínua em questões reais, mas no outro [filosofia teórica], de fazer progressos na teoria.” Cf. Ptolomeu (1984, p. 35).

77 “Também é correto denominar a filosofia como ciência da verdade. O fim da ciência teórica é a verdade, e, da ciência prática, é a ação.” Cf. Aristóteles (Met. 993b 19).
} 
em ato, ao menos como posso considerar, parece-me que tanto mais a parte especulativa exceda em nobreza a parte operativa, tanto mais a parte operativa excede não apenas em utilidade a parte especulativa, mas ainda em louvores porque, como diz Marco Túlio [Cícero] no primeiro [livro do] Dos deveres, todo louvor da virtude consiste na ação ou operação. Então um dia considerando, honorável senhor compadre, que tendo eu para comum benefício, como sabeis, traduzido e elucidado na nossa língua italiana a doutrina geométrica e aritmética de Euclides de Megara, que em tal faculdade tem o principado, julguei que tal trabalho ser digno de pouco louvor se junta dele não mostrasse a prática de saber operar e executar efetivamente, e exemplificar qualquer proposição em tais ciências ou disciplinas por Euclides desenvolvida. E para tanto deliberei em minha mente de compor para benefício comum um tratado geral de números e medidas segundo a consideração natural, como Matemática, e não apenas na prática de aritmética e geometria, e das proporções e proporcionalidades, sejam irracionais como racionais. Mas ainda na prática especulativa da grande arte dita em árabe Álgebra e Almucabala, ou regra da coisa, e assim feita tal deliberação, subitamente comecei a dar-lhe princípio, mas creio que em má hora comecei porque por volta de dois meses depois que dei início a executar meu intento, fui por dois estranhos acidentes, um após o outro, interrompido e perturbado, e não cuidei jamais de tal matéria durante oito anos. Daqueles dois acidentes, o mais agradável foi aquele de nossos amigos de Milão, que me entretiveram durante um ano a compor mapas. O segundo [acidente] então, que me foi mais estranho e muito danoso, foi aquele de nossos amigos de Brescia, se bem recordais, sobre a minha invenção atormentada. ${ }^{78} \mathrm{E}$ este segundo não apenas me perturbou, mas me tirou totalmente de tal propósito, isto é, de prosseguir tal longa empresa. Então por um tempo esperei a outro, mas o grande desejo que sempre tive de beneficiar outros (já faz dois anos) me acordou e me provocou de novo a tal grande manufatura, a qual daquela hora até aqui persegui, e com grandíssima rapidez duvidei que eu não seria outra vez impedido e perturbado perla morte ou por enfermidade, ou qualquer outra coisa. De tal modo que com ajuda daquele que tudo rege, coloquei fim nela, e este longo trabalho me pareceu que seria dividido em seis partes diferentes por causa da diversidade de seus sujeitos, das quais seis partes este é a primeira em dezessete livros dividida, na qual se declara todas as operações práticas e regras necessárias não apenas em toda a arte comercial e mercantil, mas ainda em cada outra arte, ciência ou disciplina onde intervém o cálculo. Esta primeira parte, honorável senhor padrinho, não por satisfação, mas por não parecer esquecido dos benefícios recebidos de vossa senhoria, eu a dedico e ofereço junto comigo mesmo, seu autor, rogando ao sumo Deus que por longo e feliz tempo o conserve segundo como deseja.

Em Veneza no dia 23 de Março

1556, de V.S. padrinho Niccolò Tartaglia.

\footnotetext{
${ }^{78}$ Tartaglia faz referência a seu livro Regola generale da sulevare con ragione e misvra nō solamète ogni affondata Naue: ma una Torre Solida di Metallo (Regra geral para elevar com razão e medida não apenas cada navio afundado, mas também uma torre sólida de metal), publicada em Veneza em 1551, na qual ele descreve sua "travagliata inventione".
}

RBHM, Vol. 21, nº 42, pp. 81-145, 2021 


\section{T A B E L A D A S M A TÉR I A S C O N T I D A S DE CADA LIVRO E A QUAL PÁGINA PRINCIPIA.}

NO primeiro livro (quase como um proêmio) se define a espécie da quantidade, e a que ciência, arte ou disciplina seja sobreposta cada uma das ditas espécies. Define-se ainda a Aritmética e suas espécies, e semelhantemente a unidade junto com o número, e se mostra a diferença que existe entre o [filósofo] natural e o matemático ao considerarem a dita unidade, o número etc. Pag. 2

No segundo livro se assinala as espécies do número somente enquanto aspectos da pura prática comercial ou mercantil, e depois disso se ensina as cinco primeiras e principais operações, atos ou espécies da prática de Aritmética, isto é, a representar, somar, subtrair, multiplicar e dividir os números simples ou abstratos (como usa o matemático) em todos esses modos, que foram usados por nosso antigos e modernos práticos, com vários tipos de prova. Pag. 3.

No terceiro livro se mostra então como representar, somar, subtrair, multiplicar e dividir os números, segundo consideração natural, isto é, de moedas, pesos e medidas naturais com várias espécies de prova. Pag. 37.

No quarto livro se mostra uma certa prática, que comumente informa a natureza em todo mercador (privado de regras aritméticas), e com essa prática (desde que saiba um pouco multiplicar e dividir discursivamente) saberá fazer com muita brevidade quase todas as razões difíceis que lhe possa ocorrer no vender e comprar, e esta chamamos de prática natural. Pag. 54.

No quinto livro se demonstra um outro segundo tipo de prática muito mais artificiosa e rápida da precedente, e esta chamamos de prática artificial. Pag. 75.

No sexto livro se ensina um outro terceiro tipo de prática, que em Veneza se usa, a qual serve para resolver quase toda razão dificultosa que possa ocorrer ao mercante no vender e comprar, e esta chamamos de prática veneziana. Pag. 99.

No sétimo livro se dá o modo de saber representar, somar, subtrair multiplicar e dividir números fracionários e inteiros, e fracionários por certas novas regras não ouvidas, pelas quais se aprende a razão e causa de tais operações junto com algumas outras ações, que nesses fracionários são necessários, e são as seguintes: esboçar, perguntar, furar e transportar com vários quesitos sobre aqueles para aprimorar o engenho de diletantes ou estudantes. Pag. 107.

No oitavo livro se declara aquela regra geral, que por práticos é dita de três, com todas aquelas estranhas dificuldades que possam ocorrer sobre tal regra e por diversas vias, e ao fim dela se dá a prática florentina brevemente, para não fazer outro livro em separado. Pag. 127.

No nono livro se trata de alguns tipos de razão que entre os práticos se diz compra e venda, como limitações de seus ganhos e perdas a tanto por cento, junto com o modo de saber converter moedas, pesos e medidas de uma província naqueles de uma outra. E investindo os seus dinheiros em uma província e transportando tal mercadoria comprada em uma outra província em tudo diversa de moedas, peso e medidas da 
primeira, [se trata] de saber delimitar (ao preço que se venderá) o seu ganho ou perda a tanto por cento. Pag. 163.

No décimo livro se dá e demonstra a regra de três invertida, a qual serve para calos de panos $^{79}$, de lãs cortadas, algodões etc., junto com o modo de fazer a mesa, ou tarifa para saber dar medidas a padeiros ${ }^{80}$ a respeito de quanto peso devem ter o pão em respeito ao preço do fermento junto com a regra do cinco ou das cinco coisas, com o modo de resolver vários modos de razão pertinentes a tal regra. Pag. 169.

No undécimo livro se trata de méritos e descontos simples ao fim do ano ou outra data, com o modo de saldar uma razão em tempo, como em dinheiro, junto com o modo de saber conduzir mais pagamentos feitos, ou de serem feitos em diversos tempos ou datas a uma só data; e junto com o modo de saber trazer em resto uma razão em tempo, como em dinheiro. Interposta uma regra geral não ainda ouvida, mas pelo presente autor encontrada, de saber com razão encontrar com muita brevidade a diferença de dois tempos limitados, junto com o modo de saber somar um terminado tempo com um outro terminado tempo, e assinalar o término de tal soma (digo em respeito aos milésimos de tais terminados tempos). E semelhantemente a saber subtrair um terminado tempo de um outro terminado tempo, e determinar o término de tal resto em respeito aos milésimos, matéria muito útil e necessária nas razões de mérito e descontos, e ainda nas coisas de astronomia, anotando vários erros cometidos pelo frade Luca ${ }^{81}$ e outros práticos sobre as regras de ditos méritos e descontos feitos no fim do ano. Pag. 177.

No duodécimo livro se narra e trata das companhias em todos aqueles modos, que entre os mercadores possam intervir, justificando muitos erros e regras falsas colocadas por frade Luca sobre aquelas, e semelhantemente Pietro Borgo ${ }^{82}$, Giouan Sfortunati Senese $^{83}$ e outros. E junto no fim o modo de resolver várias e diversas questões que possam ocorrer sobre os "sozzidi di bestiami”, que por toda a Itália se costumam dar aos pastores [do norte da Itália], "ovelheiros" e camponeses a certos tempos limitados por serem tais casos, ou questões pouco diferentes das companhias. Pag. 195.

No livro treze se trata de trocas em todos aqueles estranhos modos que se possa imaginar ocorrer entre os mercadores ou comunidades, anotando vários e diversos erros, e regras falsas dadas por frade Luca dal Borgo sobre aquelas e por outros. Pag. 210.

\footnotetext{
${ }^{79}$ Tartaglia escreve "calli di panni”, traduzido literalmente acima. O contexto do início do livro décimo fala de medidas de panos, e talvez "montes de panos” seja uma boa tradução. “Calli” em Veneza significa canais, e talvez Tartaglia faça referência aos mercadores de panos.

${ }^{80}$ Tartaglia escreve "calmero a pistori", e "calmero" aparentemente significa medida que vem de algum padrão oficial.

${ }^{81}$ Luca Bartolomeo de Pacioli (1445-1517), matemático italiano.

${ }^{82}$ Piero Borgi (1424-1491) escreveu o livro Aritmetica mercantile (Aritmética mercantil), cuja primeira publicação foi feita em 1484, e publicado como Libro de abacho (Livro do ábaco) em 1501. O início do primeiro capítulo começa assim: "Qui comēza la nobel opera de arithmeticha nelaqual se trata tutte cosse a mercantia pertinente fatta e compilata per Piero Borgi da Venesia." (“Aqui começa a nobre obra sobre aritmética, na qual se trata todas as coisas pertinentes ao comércio, feita e compilada por Piero Borgi de Veneza.”).

${ }^{83}$ Giovanni Sfortunati da Siena (século XVI), autointitulado "acutíssimo perscrutador da doutrina arquimediana e euclidiana", é o autor de Novo lume (Novo lume), publicado em 1544, que de acordo com Cavagna (2007) foi uma das principais fontes do General trattato (Tratado geral) de Tartaglia.
} 
No livro quatorze se narra e trata das razões de câmbio e de suas quatro espécies, isto é, câmbio pequeno ou comum, câmbio real, câmbio seco e câmbio fictício, e da forma de suas letras, do uso de termos entre uma e outra cidade, e de pagar aquela com muitas belas e sutis questões colocadas sobre cada um dos quatro tipos. Pag. 220.

No livro quinze se trata da união de metais (isto é, ouro, prata e cobre, ou outras matérias), e do "consolar" de moedas, e se dá regras gerais de saber corretamente resolver qualquer passo, caso ou questão que se possa imaginar em uma "cecca” e na arte dos ourives. Pag. 232.

No livro dezesseis se narra e trata na primeira parte os tipos de regra Helcataym ${ }^{84}$ (vocábulo Árabe), que em nossa língua quer dizer das posições falsas, e a primeira parte ou espécie de tal posição falsa é dita posição "sempia" ou primeira posição. E além da dita posição "sempia" se interpõe, e se mostra por força e virtude de números a fazer muitos jogos admiráveis e outros casos agradáveis de propor após a janta em frente ao fogo, das quais além do prazer que causa, se poderá vencer qualquer partida, e se interpõe ainda várias e diversas extravagantes questões. Pag. 240.

No livro dezessete, se declara com vários exemplos a segunda parte da regra Helcataym, dita posição dupla.

\footnotetext{
${ }^{84} \mathrm{O}$ termo deriva do nome pelo qual era conhecido entre os árabes o método da dupla falsa posição (hisāb alkhatä ayn, ou cálculo por dois erros). No Liber abaci (Livro de ábaco), Fibonacci explica o método que chama de regulis elchatayn. Em 1494 Pacioli, acompanhando seu antecessor, utilizou el cataym em Summa de arithmetica (Suma de aritmética). Schwartz (2004) indica, ainda, que o método já era tratado em textos chineses pelo nome de ying bu tsu shu (regra do excessivo e do insuficiente).
} 


\title{
4. Transcrições
}

\subsection{Euclide Megarense philosopho solo introdutore delle scientie mathematice}

\author{
E V C L I D E M E G A R E N S E \\ $\mathrm{P} \mathrm{H} \mathrm{I} \mathrm{L} \mathrm{O} \mathrm{S} \mathrm{O} \mathrm{P} \mathrm{H} \mathrm{O:}$ \\ S O L O I N T R O D V T T O R E \\ DELLE SCIENT IE M A T HEMAT I C E \\ DILIGENTEMENTE REASSETTATO, ET ALLA \\ INTEGRITA RIDOTTO PER IL DEGNO \\ Professore di tal Scientie Nicolo Tartalea, \\ B R I S C I A N O, \\ Secondo le due Tradottioni: \\ E PER COMMVNE COMMODO \\ \& vtilita di latino in volgar \\ tradotto, \\ C O N V A A M P A E S P O I T I O E \\ DELLO ISTESSO TRADOTTORE \\ DI NOVO AGGIONTA,
}

Talmente chiara, che ogni mediocre ingegno, senza la notitia, ouer suffragio di alcun'altra scientia com facilita, sera capace a' poterlo intendere.

[fol. 1v]

Quale, \& quante siano le scientie, ouero discipline Mathematice.

LE SCIENTIE, ouero discipline dette Mathematice, secondo il volgo sono molte, cioe, Arithmetica, Geometria, Musica, Astronomia, Astrologia, Cosmographia, Geographia, Corographia, Perspettiua, Specularia, La scientia de pesi, la Archittetura, \& molte altre. Ma alcuni Sapienti, prendono solamente le quatro prime, cioe, Arithmetica, Geometria, Musica, \& Astronomia: \& tutte le altre dicono esser subalternate, cioe, dependente dalle dette quatro: Alcuni altri moderni (per alcune sue ragioni) vogliono che le dette Mathematice siano cinque, peroche alle dette quatro aggiongono la Prospettiua. Nientedimeno il Reuerendis. Pietro de Aliaco, Cardinale, nella prima questione sopra Giouanni di Sacrobusto, conclude la Musica, \& la Astronomia, \& similmente la Prospettiua non essere pure mathematice (come é il vero) ma medie fra le mathematice \& la scientia naturale; perilche seguita, che solamente la Arithmetica, \& la Geometria siano pure mathematice, \& tutte le altre esser medie, ouero dependente $\&$ miste dalle mathematice discipline, \& dalla natural Philosophia: eccettuando la Astrologia giudiciaria, laqual egli conclude esser pura naturale, inquanto la sua essentia. 


\author{
[fol. 2r] \\ A L R E V E R E N D O \\ E T I L L V S T R E \\ S I G N O R \\ GABRIELLE TADINO, DA MARTINENGO \\ CAVALLIER HIEROSOLIMITANO \\ ET PRIOR DI BARLETTA DIGNISS. \\ SIGNOR SVO \\ SEMPRE OSSERVANDISSINO, \\ NICOLO TARTALEA \\ BRISCIANO.
}

TVTTI Li huomini Reuerendo Signor Priore (come scriue Aristotele nel primo della Methaphisica) naturalmente desiderano di sapere: Et nel primo della Posteriora, conclude che il saper non è altro che intendere per demostratione: Et Platone diffinisse, che la sapientia non e' altro che vna cognitione delle cose diuine, \& humane: Et molti philosophi determinano, le parti della sapientia esser due, cioè, speculatione, \& operatione, ouer prattica, \& theorica: Et Aristotele nel secondo della Methaphisica, dice che il fine della speculatione, ouer della scientia speculatiua non è altro che la verita : \& della operatione, ouer prattica l'opera compita. Et tutti li antiqui Discruttatori delle cose affirmano toccarse piu la verita nelle mathematice (cioe nella Arithmetica, \& Geometria) che in qualunque altra arte liberale; perilche determinano, quelle esser nel primo grado di certezza. E però vedemo (come dice il Cardinal di Cusa) che tutti quelli che gustano di queste due discipline, \& massime della Geometria, accostarsi a' quella in amor mirabile, come che in quella si contenga il puro cibo della vita intellettuale: Perche il Geometra solamente non si cura delle linee, ouer figure materiale, di legno, ouer di alcuno metallo, ma solamente si cura di quelle come che sono in se medesime; Auegna che quelle non si trouano fuora della materia, ma l'occhio sensibile guarda le figure sensibile, accio che le mentale possano esser viste dalla mente; Ne etiam la mente vede le figure mentale men vere, di quello che vede l'occhio corporale le sensibile: ma tanto piu vere quanto che la mente uede quelle figure in se separate dalle alterita della materia : Ma el senso esteriore mai le puo veder, ne toccare fora di quella alterita: perche la figura riceue la alterita dalla vnione di quella alla materia: perlaqual cosa è necessario vna esser differente dall'altra: perche essendo fatto vn triangolo in piana terra, \& vn'altro simile, \& eguale à quello in vna pariete, sempre si trouara fra l'uno e l'altro esserui qualche differentia: Et similmente, essendo fatta vna pyramide di pietra, \& vn'altra simile, \& eguale a' quella di legno, ouer di alcun metallo, sempre vi sara fra l'una e l'altra qualche differentia, \& tal figura pyramidale si trouara esser piu vera in vna materia che nell'altra, tamen in niuna materia vna figura puo esser cosi vera, e precisa, che la non possi esser piu vera, e piu precisa: Adonque il veder della mente vede le dette figure libere da ogni variabile alterita : \& la mente si troua senza alterita sensibile, e pero la mente è libera da ogni materia sensibile, \& quella è come forma alle figure mathematice. Et se vostra signoria generosissima dira, quelle figure esser forme; la mente fara forma delle forme : onde le figure nella mente faranno come nella sua propria forma, e pero saranno senza alterita: Adonque ciascuna cosa che la mente vede essa la vede in se medema : e per 
[fol. 2v] ro quelle cose che la mente non sono in alterita sensibile, ma in essa mente: \& quella cosa che è astratta, \& fuora de ogni alterita, non ha in se altro che verita: perche la verita non e' altro che vna carentia di alterita: Et se ben la mente nostra manca de ogni alterita sensibile, tamen quella non manca de ogni alterita. Adonque la mente laqual non manca de ogni alterita (almen della mentale) vede le figure assolte da ogni alterita, e pero lei uede quelle nella uerita, \& non fuora di se, perche la vede quelle mentalmente: \& questo non puo esser fatto fora di essa mente : perche la cosa vista mentamente non e' fora della mente: si come il senso toccando sensibilmente non e' fora del senso, ma tocca nel senso: \& la mente che vede in se medesima la cosa inalterabile, conciosia che la mente sia alterabile, la non vede la cosa inalterabile nella sua alterabilita, perche la ira impedisse l'animo che'l non puo cernere il vero, ma quello lo vede nella sua inalterabilita, \& la verita e' inalterabilita : Adonque doue che la mente vede, ciascaduna cosa laqual vede, iui e' la uerita di quella, \& di tutte le cose che essa mente uede : Adonque la uerita, nellaquale la mente vede tutte le cose e' forma della mente : e pero nella mente e' il lume della verita, per ilquale e' la mente, \& in quello essa vede se medesima, \& tutte le cose : tamen ella non vede quella verita perlaqual lei si vede se medesima, $\&$ tutte le cose, ma solamente la vede, perche la e', ma non che cosa la sia: si come il veder nostro esteriore non vede la clarita di quella luce solare, per laqual vede tutte le cose visibili, tamem el si esperimenta non veder cosa alcuna senza la detta luce solare, \& cosi sa perche le e', ma non che cosa la sia, ne etiam sa la quantita di essa luce, se non perche ella e' tanta che la eccede la vertu sua; il medesimo e' della mente: onde la verita nella mente e' come vn specchio inuisibile, nelqual la mente uede se medesima, e uede etiam tutte le cose uisibile per essa, \& quella simplicita speculare e' tanta che la eccede la uertu, \& acuita della mente: \& quanto piu è, piu si acuisse, e multiplica la uertu della mente tanto piu è certo e piu chiaro essa uede tutte le cose nel specchio della uerita: \& quella uertu cresce per la speculatione non altramente che una scintilla che inardisse ardendo: \& perche ella piglia quello accrescimento di potentia per esso lume della uerita piu, e piu la si pone in atto: Dico che quella uertu e' mandata fuora da quello lume della uerita, perche mai ella peruiene a' quel grado che quel lume della uerita non la possa tirar piu eleuata: La qual cosa, \& molte altre, considerate dalli predetti antiqui Philosophi, descruttatori della sapientia, ouer philosophia compresono (come e' il uero) non potersi senza la detta Geometria rettamente philosophare, immo [?] determinarno quella esser il uero principio e fondamento di essa sapientia, ouer philosophia: E per questa causa Platone, padre, e maestro de Philosophi non uoleua che alcuno Scholaro entrasse nella sua schola se quello prima non era in Geometria ben esperto: Ilche faceua, perche conosceua che in essa scientia geometrica ogni altra scientia occulta se ritroua. Ma perche questa Geometria non puo star per se, ne esser ben appresa senza la sua sorella Arithmetica, perilche seguita la Geometria insieme con la sua sorella Arithmetica esser il principio, \& il fondamento della sapientia. Onde touandosi à quel tempo Euclide Megarense, acutissimo philosopho, \& in tal faculta fra li altri molto perspicacissimo, quello con suo mirabile ingegno reassetto' in quindeci libri regolatamente queste due discipline, Geometria, \& Arithmetica (si in operatione come in speculatione) con tanto altro \& mirabil ordine quanto che huomo imaginar potesse, $A^{\prime}$ tal che da quel tempo per fin al presente, senza contradittione, ottiene il principato in tal facolta. Et perche à quel tempo (per commun ordinedi essi Philosophi) la prima cosa che si faceua imparare a' tutti quelli che si 
dedicauano alla sapientia, era la Arithmetica, \& la Geometria, lui volse intitolare, e chiamar la detta sua opera, Opera di principii: quasi uolendo dire Opera di principii e fondamenti della Sapientia, ouer Philosophia: Et questo ordine antico fu osseruato \& mantenuto gran tempo. Ma al presente da moderni non solamente e' stato corrotto, ma talmente annullato, che le dette due scientie sono quasi deperdite: \& [fol. 3r] la preuaricatione di tal antico ordine (per quanto posso considerare) e' processo per le infrascritte cause, prima, per la nata variatione delle lingue: perche ciascun desiderante d'andar a' fruire il nobil giardino della Sapientia, al presente gliè necessario che cerchi principalmente d'intender la lingua delli antiqui Autthori, che l'hanno da porre in su la retta via, (laqual cosa antiquamente non era necessaria, perche tal lingua era a' loro propria) \& circa cio consumma tal parte di tempo, che non solamente seria basteuole per intendere li detti principii, ma anchora la maggior parte della cosa desiderata : E dapoi che hanno imparata la detta lingua con gran fatica e sudore, e senza alcuna parte, ne principio della cosa desiderata : La maggior parte como stanchi \& lassi (per abbreuiar il camino, \& recuperar il tempo scorso) abbandonano la detta via antiqua, [et] ${ }^{85}$ si drizzano per vno certo calle, ouer sentiero modernamente trouato. E se pur alcuno (come prudente) si mette a' studiare l'Opera del detto sapientissimo philosopho Euclide, oltra che'l trouera quella disregolata, e deprauata, (come manifestamente si vede nelle due Tradottioni.) Ma come quello aggionge alla quinta, sesta, \& ottaua diffinitione del quinto libro imita il moto delli nodi del dragone con laborioso affanno: \& questo e' per cagion dalcune interpositioni del Campano (se pur sono interpositioni del Campano) qual credendosi dilucidar tal diffinitioni (per la sua puoca intelligentia) le ha talmente confuse, che'l studente per niun modo puo cauar alcun construtto, perilche è sforzato abbandonar l'impresa, e drizzarsi como li altri per il moderno calle, ouer sentiero. E da qui forsi nasce che li nostri moderni non possono aggionger al segno oue aggionseno li antiqui: \& diragione dourebbono pur trappassare piu oltra, conciosia che é facile lo aggiongere alle cose trouate. Onde fra me pensando alla grandissima vtilita che di queste due discipline ne consegue percoloro che le sanno secondo li debiti bisogni allo intelletto accommodare, accio che quelle tornino nel pristino stato, \& che l'Opra dello ingeniosissimo Euclide sia riconosciuta, non solamente ho vogliuto durar questa fatica di riassettarla \& integrarla secondo le due Tradottioni, ma etiam per commune vtilita dal latino in volgar tradurla, \& dilucidarla con espositioni talmente chiare (sopra tutte le diffinitioni, \& altri oscuri passi) che ogni mediocre ingegno, senza notitia di alcuna altra scientia sera capace di intenderla. Ne di questo vostra Reuerentia simarauiglii, pero che queste due scientie, ouero discipline non hanno dibisogno di alcuna altra scientia, inquanto alla lei essentia, ma ben tutte le altre hanno bisogno di loro, come nel processo a' quella lo faro cognoscer, \& vedere: \& non solamente le liberali, ma etiam tutte le mecanice. Dapoi fra me pensando a' cui tal mia vtil fatica dedicar douessi, certo niun piu degno di vostra R. (per moltissimi ragioni) mi è possuto venire $[\mathbf{a}]^{86}$ memoria, per essere quella non solamente amatrice, \& ricettacolo di virtu, ma vn vaso di prudentia, somma di generosita, fonte di magnanimita, lago di liberalita, fiume di consiglio, e mare d'altro ingegno, misto di humanita, a' cui tutte le opre di virtu concorrer debbono come a' suo proprio albergo. Onde per non preterir alli termini di ragione, à quella la dedico, offerisco, \&, dono : Ne quella

${ }^{85}$ Escrito manualmente na edição utilizada.

${ }^{86}$ Escrito manualmente na edição utilizada; no canto esquerdo do fólio está escrito "alla”. 
tenga tal due scientie a' vile, però che (come di sopra e' detto) antiquamente furno reuerite, cercate, \& celebrate da tutti li perspicacissimi ${ }^{87}$ ingegni, mediante lequali non solo son peruenuti alla notitia e cognitione delle cose terrene, a' noi mortali necessarie, ma etiam per mezzo di quelle son venuti in cognitione delle diuine Questo testifica il gran Philosopho Pithagora, ilqual tutta la sua dottrina \& theologia mediante li numeri dipinse: Imperoche come scriue Salomon sapientissimo, Deus omnia fecit in pondere, numero, \& mensura. non ostante che'l si legga nell'Ecclesiastico al.c.1. Altitudinem caeli, \& latitudinem terre, \& profundum abyssi quis dimensus est: Nientedimeno tanta e' la virtu di queste due scientie, ouer discipline, cioe, Arithmetica, e Geometria insieme con la sua figliola Prospettiua, che mediante quelle noi cognosciamo pervirtu del compasso, e delle proportioni quanta sia la rotondita di tutta la terra, \& quanto sia il diametro suo, \& similmente delli al [fol. 3v] tri elementi: Perche come dice Aristotele, lo elemento superiore èdiece volte quanto il suo immediate inferiore. Verbi gratia, l'acqua e' diece volte quanto è tutta la terra: similmente, l'aere e' diece volte quando e l'acqua: il fuoco è mille volte quanto è tutta la terra: $E$ nondimeno la grandezza di questi corpi grandissimi si cognoscono nell'arte della Astronomia per scientia Geometrica, mediante la Perspettiua, \& per via del calculo. Ma p[er]che li scrittori delle lettere (come scriue Isidorio nel.3. delle Ethimologie) voleno che l'Arithmetica fia la prima delle discipline mathematice, impero' primamente in laude di quella diremo alcune p[ro]positioni. Certa cosa è qualmente quella e' nutrice $\&$ matre delli Musici (come afferma Boetio Seuerino, \& similmente Franchin Gafforo nella sua musica,) imperoche senza li numeri, \& le sue p[ro]prieta, p[ro]portione, \& proportionalita, non si puo cognoscere chiaramente la consonantia, \& dissonantia di tre, ouer piu voci, ma con quella el si cognosce che vna quinta, ouer ottaua fanno souauissima armonia, \& grandemente dillettano lo audito delli audienti, \& similmente con la detta scientia de numeri sappiamo che vna quarta grande dissonantia, \& non puoco turba lo audito. Questa con le sue regole calculatorie, \& virtu, de suoi numeri da la via all'arte giuditiaria detta Astrologia, \& similmente alla Pyromantia, Hydromantia, Necromantia, Geomantia, Horospitio, Aruspitio, Augurio, Auspitio, \& ad altri Sortilegii. E questo scriue il predetto Isidoro, \& Cieco di Ascoli, \& similmente Cornelio Agrippa nel secondo de occulta Philosophia. Ma piu, essendo vn giorno adimandato il diuin Platone, per qual causa l'huomo, tra li animali rationatit ${ }^{88}$, era chiamato animal diuino. Alche rispose, e', perche l'huomo sa numerare, \& le bestie non. Quasi volendo dire, che a' cognoscer li numeri, con le sue proprieta, era cosa diuina, ouero, che con li numeri l'huomo vien in cognitione delle cose, alte, e peregrine. Anchora per questa scientia di Arithmetica, ouero con le proportioni de suoi numeri el si cognosce nella scientia di Geometria le quantita communicanti, \& incommunicanti, o' vuoi dir, commensurabili, \& incommensurabili: \& similmente, le rationale, \& irrationale, come nel de cimo del nostro Euclide si manifesta: \& similmente, quella con numeri ce illumina e ci fa capaci della quantita d'ogni figura Geometrica, cioe, de Triangoli, Quadrati, Tetragoni longhi, Penthagoni, Essagoni, Rhombi, \& Rhomboydi, \& d'ogni altra figura piana : similmente d'ogni corpo solido, si regolare come irregolare, come sono Pyramide, Prisme, ouer Serratili, Sphere, Coni, cylindri, ouer Colonne, Cubi, Ottobase, Dodecibase, Vintibase, con tutte le sue p[ro]prieta, e proportioni, come etiam

${ }^{87}$ Um sinal remete às palavras “et faui”, escritas manualmente no canto esquerdo do fólio.

${ }^{88}$ Palavra riscada manualmente na edição utilizada; no canto esquerdo do fólio está escrito “inrationali”. 
Geometricamente descriue, \& forma il nostro egregio Autthore Euclide in quindeci libri: delliquali vndeci sono di Geometria, cioe, il $\mathrm{p}^{\circ}$. il. $2^{\circ}$. il. $3^{\circ}$. il. $4^{\circ}$. il. $6^{\circ}$. il. $10^{\circ}$. lo $11^{\circ}$. il $12^{\circ}$. il $13^{\circ}$. il $14^{\circ}$. \& il $15^{\circ}$. \& tre sono di Arithmetica, cioe, il. $7^{\circ}$. lo. $8^{\circ}$. \& il $9^{\circ}$. Il $5^{\circ}$. a tutti questi e' commune, il qual e' della proportione, \& proportionalita: la qual proportione, \& proportionalita cosi se aspetta al numero come alla misura. E tantae' la vtilita, oltra la souaita [,] [et] ${ }^{89}$ dolcezza di studio che si troua nelle contemplationi mathematice, piene di certezza, che Archimede siracusano per il studio di quelle con suoi mecanici ingegni diffesi vn tempo la Citta di Siracusa contra l'impeto di Marco marcello Consule Romano, p[er]ilche acquisto' il nome della immortalita. Per virtu di queste Dedalo peritissimo fabricò il nominato Laberinto al Minotauro. Per mezzo di queste si fanno varii, \& diuersi modelli: fabricansi ponti con archi, quasi alla natura impossibili. Anchora chi con l'intelletto ben considera tutte lesorte di antique \& moderne machine, \& istromenti bellici, si offensiui come defensiui, come sono bastioni, ripari, bricoli, trabocchi, catapulce, scorpioni, baliste, ariete, testudine, helepoli; come dimostra Vettruio nel decimo, sempre con forza di numeri \& misure le loro proportioni si trouano formate, \& fabricate. Delle noue inuentioni per metrouate sopra il tirar delle moderne machine tormentarie (dette dal volgo, arti gliarie) non voglio replicarlo: per hauerlo altronde detto, \& in parte publicato. Basta solamente á dire, che per consiglio di queste (senza alcuna prattica in tal esercitio) la maggior parte ritrouai. Da queste medesime discipline germoglia, \& nasce [fol. 4r] la scientia de pesi: come apertamente dimostra Iordano in quello de ponderibus, per mezzo della qual scientia Aristotele nelle sue questioni mecanice assegna la causa d'ogni miracolosa mecanica inuentione. Di quanto aiuto e presidio siano le dette due scientie, ouer discipline alla Archittetura Vittruuio Pollione nel suo Prohemio la fa manifesto. Anchora che ben considera \& guarda la scientia Perspettiua, senza dubbio si trouera che nulla sarebbe, se la Geometria come matre non se gli accomodasse. Questo ci manifesta il detto nostro Euclide nella sua Perspettiua: e similmente l'Arciuesco Giouāne Cantuariense, ma piu abondantemente Viteleone, ilqual ogni sua propositione approua, e dimostra con le Euclidiane propositioni. Che diremo della Cosmographia, \& Geographia: Non ci dimostra Ptholomeo, \& tutti li altri eccelentissimi Cosmographi, \& Geographi, quanto gli siano necessarie queste due scientie, ouer discipline. Quando de tutto l'uniuerso, debitamente p[ro]portionando li lor gradi delle longitudine, e latitudine, rendano invna piccol carta tutte le famose Prouince, Citta, Castelli, Monti, Fiumi, Isole, \& altri siti maritimi, \& mediterranei (come piu volte insieme con V. R. sopra la sua Carta nauigatoria, habbiamo discorso, \& visto, \& similmente sopra il suo Globo Alemanico.) Et quella sappia che non per altra causa al presente e' penuria di buoni, \& eccellenti Astronomi, saluo che per diffetto, \& ignorantia delle predette due scientie, ouero discipline: Perche di ben intender l'Almagesto di Ptholomeo, \& similmente Giouan de Monte Regio, senza le Euclidiane instruttioni, nium certo si puo auantare. Piu forte, Bartolo da Sassoferrato nella sua Teberina, sue figure geometrice vsando, espressamente dimostra la Geometria esser necessaria in iure. Piu oltra, la guida, \& scorta di nostra salute, sacra Theologia, non dimostra apertamente il R. Cardinale Nicolo di Cusa, nella penultima parte dell’Opra sua, senza detta Geometria nou puotersi alli intelletti nostri communicare; Laqual parte e' intitolata, Complementum

${ }^{89}$ Escritos manualmente na edição utilizada. 
Theologicum figuratum in complementis mathematicis: Ma piu, eglie di tanta necessita questa Geometrica disciplina, \& scientia, che non solamente li huomini mortali nelle sue cose commensurabile vsano quella (come di sopra piu volte é detto) ma anchora il magno Iddio, ilqual è misura di tutte le cose, in formar le parti del corpo humano non si gouerna senza quella, con laqual anchora questi Compositori de imagini, \& pittori eccellenti si corformano, ad ogni membro vsando il suo compasso: Perilche etiam li peritissimi Architteti (come ci manifesta Vittruuio Pollione al primo capitolo del suo terzo libro) cercano con ogni diligentia di proportionar la Aede, \& altri suoi publici, e priuati hedificii alla similitudine di detto corpo humano, per esser questo (come e' detto) dal sommo Archittetore, con debite misure fabricato. Anchora el si conosce la nobilita, eccellentia, \& altezza di detta Geometria, per la grande fama, \& nome di quelli, liquali hanno dato opera ad exornar, e studiar detta scientia; come furno Mercurio Termegisto philosopho, Sacerdote, \& Re d'Eggito: similmente Pithagora, Platone, Plotino, Aristotele, Auerrois, Hypocrates, el nostro Euclide, Ptholomeo, Archimede, Appollonio Pergeo, Iordano, Vittruuio Architteto, \& molti altri: liquali per breuita li lasso, per non tediar piu l'auditorio senso di V. R. parendomi che per le cose dette, \& allegate quella debba esser, nō solamente informata, \& aduertita qualmente le gia dette discipline non sono fauole, ne altre ridicolose, \& false facetie: ne simmilmenteinuentioni incredibile poetice, che di vento \& fummo le orecchie nostre paschino: ma totalmente accertata (come e' il vero) quelle non sol amente esser vere, ma verissime (come in principio fu detto) e nel primo grado di certezza, come anchora afferma Aristotele nel primo della Posteriora, testo. 25. \& similmente Auerrois sopra il. 2. della Methaphisica: Perilche non dubito que vostra R. hauera tal cosa agrata: perche son certo che quella con suo mirabile Ingegno, \& natural discorso nelle sua cose accidentale ne cauera construtti grandissimi, alla qual con humile e debita reuerentia sommamente me aricommando: Pregando l'omnipotente Iddio gli piacia di restituigli la sua pristina sanita, e quella accrescer, e conseruar con tutti i suoi adherenti, e beniuoli, secondo ogni suo buon desiderio. Vale. 


\subsection{Inventione de Nicolo Tartaglia Brisciano intitolata Scientia noua}

\section{[fol. 1v]}

I N V E N T I O N E D E N I C O L O

Tartaglia Brisciano intitolata Scientia noua diuisa

in. 5. libri: nel Primo di quali : se dimostra theo-

ricamente : la natura : \& effeti de corpi

egualmente graui : in li dui contrarij

moti che in eßi puon accadere:

et de lor cōtrarij effetti.

$€$ In lo secondo (geometricamente) se approua, e dimostra la qualita similitudine, \& proportionalita di transiti loro secondo li uarij modi, che puono esser eietti, ouer tirati uiolentamente per aere, \& similmente delle lor distantie.

$€$ In lo terzo se insegna una noua pratica de misurare con l'aspetto, le altezze distantie ypothumissate, \& orizontale delle cose apparente, e giontoui anchora la theorica, cioe la ragione \& causa di tal operare.

$€$ In lo quarto se dara la p[ro]portione de l'ordine dil crescere callar che in ogni pezzo de artegliaria nelli suoi tiri, alzādolo ouer arbassandolo, sopra il pian de l'orizonte, \& similmente ogni mortaro, anchora se insegnara il modo di trouar tutte le dette uarieta, ouer quantita de tiri in ogni pezzo de artegliaria, ouer mortaro mediante la notitia dun tiro solo. Anchora si mostrara il modo come si debbia gouernar un bombardiero quando desidera, di battere ouer di percottere in qualche luoco apparente.

Oltra di q[ue]sto se insegnara ancora il modo come si debia gouernar il dettobōbardiero quando gli fusse fatto riparo dauanti al luoco doue percotte, uolendo pur percottere nel medemo luoco p[er] altra uia, ouer elleuatione quātunq[ue] piu nō ueda q[ue]l tal luoco.

$€$ Anchora se dara il modo di sapere percottere continuamente la oscura notte in un luoco appostato il giorno auanti.

$€$ In lo quinto libro se dichiarira (secondo l'auttorita de molti Eccelentißimi Natura li) la natura, \& origine de diuerse specie di gome, olei acque stilllate, anchora de didiuersi simplici minerali \& nō minerali dalla natura prodotti, \& da l'arte fabricati, anchora se manifestara alcune sue particolare proprieta circa a larte de fuochi. Et similmente se delucidara quale sono quelle materie chi se conuiengono \& che se accordano \& quale sono quelle che non si conuiengono ne se accordano, a ardere insieme, \& consequentemente se dara il modo di componere, uarie $\&$ diuerse specie di fuochi, non solamente, alla defensione de ogni murata terrra utilißimi, ma anchora in molte altre occorentie molto a proposito. 
[fol. 2r]

A L L O ILL V S T R IS S IMO E T IN V I C T IS S IMO S I G N O R

Francescomaria Feltrense dalla Rouere Duca Eccelentißimo di Vrbino \&

di Sora, Conte di Montefeltro, \& di Durante. Signor di Senegalia, \& di Pesaro, Prefetto di Roma . \& dello Inclito Senato Venetiano Dignißimo General Capitano.

\section{EPISTOLA.}

HABITANDO IN VERONA L'ANNO MDXXXI. Illustrißimo. S. Duca mi fu adimandato da uno mio intimo et cordial amico Peritißimo bombardiero in castel uecchio (huomo atēpato \& copioso di molte uirtu) dil modo de mettere a segno un pezzo de arteglieria al piu che puo tirare. $\mathrm{E}$ a benche in tal arte io non hauesse pratica alcuna (per che in uero Eccellente Duca) giamai discarghetti artegliaria, archibuso, bombarda, ne schioppo) niente di meno (desideroso di seruir l'amico) gli promißi di darli in breue rissoluta risposta. Et di poi che hebbi ben masticata \& ruminata tal materia, gli conclusi, \& dimostrai con ragioni naturale, \& geometrice, qualmente bisognaua che la bocca dil pezzo stesse elleuata talmente guardasse rettamente a. 45. gradi sopra a l'orizonte, \& che per far tal cosa ispedientemente bisogna hauere una squara de alcun metallo ouer legno sodo che habbia interchiuso un quadrante con lo suo perpendicolo come di sotto appar in disegno, \& ponendo poi una parte della gamba maggiore di quella (cioe la parte. b e.) nel'anima ouer bocca dil pezzo distesa rettamente per il fondo dil uacuo della canna, alzando poi tanto denanti il detto pezzo che il perpendicolo. h d. seghi lo lato curuo. e g f. (dil quadrante) in due parti eguali (cioe in ponto g.) All'hora se dira che il detto pezzo guardara rettamēte a. 45. gradi sopra al orizonte. Perche (Signor clarißimo) il lato curuo. e g f. del quadrante (secondo li astro-

[fol. 2v] nomi) se diuide in. 90. parti eguale \& cadauna di quelle chiamano grado. Pero la mita di quello (cioe. g f.) uerria a esser gradi. 45. Ma per acordarse con quello che se ha da dire lo hauemo diuiso in. 12. parti eguali \& accioche uostra Illustrißima D. S. ueda in figura quello che di sopra hauemo con parole depinto hauemo qua disotto designato il pezzo con la squara in bocca assettato secondo il proposito da noi conchiuso al detto nostro amico. La qual conclusion a esso parse hauer qualche consonantia pur circa cio dubitaua alquanto parendo a lui che tal pezzo guardasse troppo alto. Ilche procedeua per non esser capace delle nostre ragioni, ne in le Mathematice ben corroborrato, niente di meno con alcuni isperimenti particolari in fine se uerifico totalmente cosi essere.

Pezzo elleuato alli. 45. gradi sopra al'orizonte.

Ma piu nel anno MDXXXII. essendo per Prefetto in Verona il Magnifico misser Leonardo Iustiniano. Vn capo de bombardieri amicißimo di quel nostro amico. Vene in concorrentia con un altro (al presente capo de bombardieri in Padoa) \& un giorno accadete che fra loro fu proposto il medemo che a noi proposse quel nostro amico, cioe a che segno si douesse assetare un pezzo de artegliaria che facesse [fol. 3r] il maggior tiro che far possa sopra un 
piano. Quel amico di quel nostro amico gli concluse con una squara in mani il medemo che da noi fu terminato cioe come di sopra hauemo detto \& designato in figura.

L'altro disse che molto piu tiraria a dui ponti piu basso di tal squara (la quale era diuisa in. 12. parti) come disotto appare in disegno.

Et sopra di questo fu deposta una certa quāntita de danari, \& finalmente ueneno alla sperientia, \& fu condotta una colobrina da. 20. a Santa Lucia in campagna, \& cadauno di loro tiro secondo la proposta senza alcun auantaggio di poluere ne di balla, onde Quello che tiro secondo la nostra determinatione, tirò di lontano (secondo che ne fu referto) pertiche. 1972. da piedi. 6. per pertica, alla ueronesa, l'altro che tirò li dui ponti piu basso, tirò di lontano solamente pertiche. 1872. per laqual cosa tutti li bombardieri \& altri se uerificorno della nostra determinatione, che auanti di questa isperientia staseuano ambigui imo la maggior parte haueuano contraria opinione parendoli che tal pezzo guardasse troppo alto. Ma piu forte uoglio che uostra Preclarißima Signoria sappia che di tre cose è forza che ne sia una, ouer che li misurāti ferno errore nel misurare, ouer che a me non fu refferto il uero, ouer che il secondo [fol. 3v] cargo piu diligentemente dil primo. Perche la ragiō ne dimostra che il secondo (cioe quello che tirò li dui ponti piu basso tirò alquanto piu dil douere alla proportione del primo, ouer che il primo tirò alquanto māco di quello che doueua tirare alla proportione del secondo, come nel quarto libro (doue trattaremo de la proportion di tiri) in breue quella potra conoscere e uedere. Et sappia uostra Magnanimita che per esser stato all'hora in tal materia desto deliberai di uoler piu oltra tētare. Et cominciai ( $\&$ non senza ragione) a inuistigare le specie di moti che in un corpo graue potesse accadere, onde trouai quelle esser due cioe naturale, $\&$ uiolente, et quegli trouai esser totalmente in accidenti contrarij mediante li lor contrarij effetti, similmente trouai cō ragione alintelletto euidente esser impoßibile mouersi un corpo graue di moto naturale \& uiolente insieme misto Dapoi inuestigai con ragion geometrice demostratiue la qualita di transiti, ouer moti uiolenti de detti corpi graui, secondo li uarij modi che pono esser eietti ouer tirati uiolentemente per aere. Oltra di questo me certificai con ragioni geometrice demostratiue. Qualmente tutti li tiri de ogni sorte artegliarie, si grande come piccole egualmente elleuate sopra il pian de l'orizonte, ouer egualmente oblique, ouer per il pian de l'orizonte, esser fra loro simili \& consequentemente proportionali \& similmēte le distantie loro. Dapoi conobbi cō ragion Naturale qualmente la distantia dil sopra detto tiro elleuato alli. 45. gradi sopra a l'orizonte, era circa decupla al tramito retto dun tiro fatto per il piano del orizonte: che da bombardieri è detto tirar de ponto in bianco, con laqual euidentia Magnanimo Duca trouai cō ragioni geometrice \& algebratice qualmente una balla tirata uerso li detti. 45. gradi sopra a l'orizonte ua circa a quatro uolte tanto per linea retta di quello che ua essendo tirata per il pian del orizonte che da bombardieri è chiamato (come ho detto) tirar de ponto in bianco. Per ilche si manifesta qualmente una balla tirata da una medema artegliaria ua piu per linea retta p[er] un uerso che per un'altro \& consequentemente fa maggior effetto. Anchor Signor Illustrißimo calculando trouai la proportion, dil crescere e calar che fa ogni pezzo de artegliaria (nelli suoi tiri) alzandolo ouer arbassandolo sopra il pian del orizonte, $\&$ similmente trouai il modo di saper trouar la uarieta de detti tiri in cadaun pezzo si grande come piccolo mediante la notitia dun tiro solo 
(domente che sempre sia egualmente cargato) Dapoi inuestigai, la proportione \& l'ordini di tiri del mortaro, \& similmente trouai il modo di saper inuistigare sotto breuita la uarieta de detti tiri pur per mezzo dun tiro solo. Oltra di questo con ragioni euidentißime conobbi qualmente un pezzo de artegliaria posseua per due diuerse uie (ouer elleuationi) percottere in un medemo luoco \& trouai il modo di mādar tal cosa (accadēdo) a essecutione (cose nō piu audite ne d'alcun altro antico ne moderno cogitate) Ma dapoi cōsiderai (Signor Magnifico) che tutte q[ue]ste cose erano dipuoco giouamēto a un bōbardiero quādo che la distātia dil luoco doue gli occoresse di battere non gli fusse nota. Essempi gratia occorrendogli a tirare in un luoco apparente che la distantia di quello gli fusse occulta Che gli giouaria (O Magnanimo Duca) in questo caso che lui sapesse che il suo pezzo tirasse alla tal elleuatione passa. 1356. \& alla tal altra passa. 1468. \& alla tal altra passa. 1574. \& cosi discorrendo de grado in grado, certo nulla li giouaria, perche non sapendo la distantia, [fol. 4r] manco sapra a che segno, ouer elleuatione debba assettar tal suo pezzo de artegliaria che percotta nel desiderato loco. Seguita adōque due esser le principal parti necessarie a un real bombardiero (uolendo tirar con ragione \& non a caso) delle quale l'una senza l'altra quasi niente gioua. (Dico nelli tiri lontani.) La prima è che grosso modo sappia conoscere \& inuestigare (con l'aspetto) la distantia dil luoco doue gli occorre de tirare. La seconda è che sappia la quantita di tiri della sua artegliaria, secondo le sue uarie elleuationi, le qual cose sapendo non errara de molto nelli suoi tiri, ma mancandoui una di quelle non puo tirar (in conto alcuno) con ragione ma solamente a discretione et se per caso percotte al primo colpo nel luoco, ouer a presso al luoco doue desidera, è piu presto per sorte che per scientia (dico pur nelli tiri lontani.) Perilche (Signor Illustrißimo) trouai un nouo modo da inuestigar sotto breuita le altezze, profondita, larghezze, distantie ypothumissale, ouer diametrale, \& ancora le orizontale delle cose apparente, non in tutto come cosa noua. Perche in uero Euclide nella sua perspettiua sotto breuita theoricamente in parte ne linsegna, similmemte Giouanne Stoflerino, Orontio, Pietro Lombardo \& molti altri hanno datto a tal materie norma, chi con il sole, chi con un specchio, chi con il quadrāte, chi cō lo astrolabio, chi con due uirgule, chi con un bastone (intitolato baculo de Iacob) \& in molti altri uarij modi. Ma io dico (Signor Clarißimo) che trouai un nouo modo ispidiente e presto $\&$ facile da capire a cadauno ( $\&$ a men errori suggetto de qualunque altro) da inuestigare le dette distantie, il quale da niun altro è stato posto Maßime delle distantie ypothumissale ouer diametrale anchora delle orizōtale, lequale inuero sono le piu necessarie al bombardiero de tutte le altre sorte di dimensioni, perche a quello non é molto necessario a sapere la altezza duna cosa perpendicolarmente elleuata sopra al orizonte, ne anchora la profondita duna cosa profunda, ne anchora la larghezza duna cosa lata. Ma solamente le dette distantie ypothumissale, \& orizontale gli sono molto al proposito, come nel quarto libro (a uostra Illustrißima Signoria) si fara manifesto. Oltra di questo per curiosita, me misse a scorrere li uarij modi osseruato da nostri antiqui Naturali, \& anchor da moderni nelle compositioni de fuochi \& fra naturali inuestigai la natura di quelle gumme, bitumi, graßi, olei, sali, acque stillate, \& altri simplici minerali, \& non minerali dalla natura prodotti, \& da l'arte fabricati, componenti quelli, \& consequentemēte trouai il modo di componere molte altre uarie \& diuerse specie de fuochi non solamente alla diffensione de ogni murata terra utilißimi, ma anchora in molte altre occurrentie molto al proposito. Per le quai cose, haueua deliberato de regolar l'arte de bombardieri, $\&$ tirarla a quella sotilita, che 
fusse poßibile de tirare (mediante alcune particolar isperientie) perche in uero (come dice Aristotile nel settimo della Physica testo uigesimo) dalla isperientia di particolari pigliamo la scientia uniuersale. Ma poi fra me pensando un giorno, mi parue cose biasmeuole, uituperosa, e crudele, \& degna di non puoca punitione apresso a Iddio, \& alli huomini a uoler studiare di assotigliare tal essercitio dannoso al proßimo, anzi destruttore della specie humana, \& massime de Christiani in lor continue guerre. Per ilche non solamente pospossi totalmente il studio di tal materia \& attesi a studiar in altro, ma anchor strazzai, \& abrusciai ogni calculatione, \& scrittura da me [fol. $4 \mathbf{v}$ ] notata: che di tal materia parlasse. Et molto mi dolsi, \& auergognai dil tempo circa a tal cosaspesso \& quelle particolarita, che nella memoria mi restorno (contra mia uolunta) iscritte mai ho uoluto palesarle ad alcuno, ne per amicitia, ne per premio (quantunque sia stato da molti richiesto) perche insignandole mi parea di far naufragio e grāde errore. Ma hor uedēdo il luppo desideroso de intrar nel nostro armēto \& accor dato insieme alla diffesa ogni nostro pastore nō mi par licito al presente di tenere tai cose occulte, anci ho deliberato di publicarle parte in scritto, \& parte uiua uoce a ogni christiano, accioche cadauno sia meglio atto si nel offendere come nel diffendersi da quello. Et molto mi doglio uedendo il bisogno che tal studio all'ora abādonai, perche son certo che hauendo seguito fin hora harei trouato cose di maggior ualore come spero in breue anchora ditrouare. Ma perche il presente è certo (è al tempo breue) il futuro è dubioso uoglio ispedire prima quello che al presente mitrouo \& per man dar tal cosa imparte a essecutione ho composto impressia la presente operina: laquale si, come ogni fiume naturalmente cerca di accostarse \& unirse col more, cosi essa conoscendo uostra Illust. D. S. esser la somma fra mortali de ogni bellica uirtu) recerca di accostarse, \& unirse con essa amplitudine, Pero si come lo abondante mare: ilquale non ha di acqua bisogno non se sdegna di receuer un picol fiume, cosi spero che uostra D. S. nō se sdegnara di, acettarla accioche li peritissimi bombardieri di questo nostro Illustrissimo Dominio sugetti a uostra Sublimita, oltra il suo ottimo \& pratical ingegno, siano meglio di ragion istrutti, \& atti a esseguire li mandati di quella. Et se in questi tre libri non satisfaccio plenariamente uostra Eccellentissima Signoria insieme con li predetti suoi peretissimi bombardieri, spero in breue con la pratica del quarto \& quinto libro non gia in stampa (per piu rispetti) ma ben a penna, ouer uiua uoce di satisfar in parte uostra Sublimita insieme con quegli alla cui gratia da Infimo \& humilissimo Seruitore Diuotamente mi raccomando.

Data in Venetia in le case noue di San Saluatore alli. XX di Decembrio. MDXXXVII.

De uostra Illustrissima D.S. Infimo Seruitore.

Nicolo Tartaglia Brisciano. 


\subsection{General trattato di numeri et misure}

\section{A P R I M A P A R T E D E L GENERAL TRATTATO D I N V- MERI, ET MISVRE DI NICOLO TARTAGLIA,}

N E L L A Q V A L L E I N D I E C I S E T T E

L I B R I S D I C H I A R A T V T T I GL I A T T I O P E R A T I V I, PRA T I C HE, ET REG OLE NECESSARIE N O N S O L Amente in tutta l'arte negotiaria, \& mercantile, ma anchor in ogni altra arte, scientia, ouer disciplina, doue interuenghi il calculo.

In Vinegia per Curtio Troiano de i Nauò, M D L V I.

[fol. 2r]

\section{A L M O L T O N O B I L E E T E G R E G I O S G NOR I L SIGNOR RICARDO VENTVORTH, GENTIL'HVOMO INGLESE, COMPAR, ET MAGGIOR SUO HONORANDISS.}

Gli antichi sapienti, honorando signor compare (comme scriue Ptolomeo nel principio del Almagesto) diuiderno la sapientia in due parti, la prima dellequali dal detto Ptolomeo è detta speculatione, \& l'altra é chiamata operatione, lequali due parti communamente anchora l'una è detta Theorica, ouer speculatione, \& l'altra Pratica, ouer attiua, ouer operatiua, fra lequali due parti (come afferma esso Ptolomeo) non ui è puoca differentia, la causa è che tendono a diuerso fine, perche il fine della scientia speculatiua (come dice Aristotile nel secondo della Metaphisica) non é altro, che la uerita, \& della operatione, ouer pratica l'opera compita, $\&$ abenche la speculatione (per esser inuestigatrice delle propinque cause, et augmentatrice della scientia) sia molto piu nobile della operatione, ouer pratica operatiua, laquale solamente attende a sapere con diligenza essequire, \& condur attualmente a fine, ouer ad effetto tutte le cose gia speculatiuamente ritrouate, notificate, \& regolatamente in atto poste, nondimeno per quanto posso considerare, a me mi pare, che quanto piu la parte speculatiua ecceda di nobilta la parte operatiua, tanto piu la parte operatiua ecceda, non solamente di utilita, la parte speculatiua, ma anchora di laude, perche, come dice M. Tullio nel primo de officis, [fol. 2v] ogni laude della uirtu consiste nell'attione, ouer operatione. Onde considerando un giorno honorando signor compare, che hauendo io a comun beneficio (come sapeti) tradutto, \& delucidato nella nostra lingua Italiana la speculatiua dottrina Geometrica, \& Arithmetica di Euclide Megarense, che in tal faculta ottiene il principato, giudicai tal mia fatica esser di poche laudi degna, se appresso di quello non mostraße la pratica di saper operare, \& attualmente essequire, \& essemplificar 
qual si uoglia propositione in tai due scientie, ouer discipline da esso Euclide adutta. E per tanto deliberai nella mente mia di componere a comun beneficio un general trattato di numeri, \& misure, si secondo la consideration naturale, come Mathematica, \& non solamente nella pratica di Arithmetica, \& di Geometria, \& delle proportioni, \& proportionalita, si irrationali, come rationali. Ma anchor nella pratica speculatiua dell'arte Magna detta in Arabo Algebra, \& Almucabala, ouver regola della cosa, \& cosi fatta tal deliberatione, subito cominciai a darui principio, ma credo che in cattiua hora li incominciasse, perche circa duoi mesi dopo che hebbi dato principio a essequir tal mio intento, fui da duoi strani accidenti l'uno dietro all'altro, talmente interrotto, \& disturbato, che son stato circa otto anni, que a tal maieria giamai ha posto cura, delliquali duoi accidenti, il piu piacieuole fu di quelli nostri amici di Milano, che m'intertenirno circa un anno a componer cartelli. Il secondo poi, qual mi fu piu strano, \& danoso assai, fu di quelli nostri amici di Brescia, deliqualli (se ben ui aricordati) sopra la mia trauagliata inuentione, in parte ue ne ragionai. Et questo secondo non solamente mi disturbo, ma mi tolse totalmente giu di tal proposito, cioe di proseguire cosi longa impresa. Onde per un tempo io attesi ad altro, ma il gran desiderio, che ho sempre hauuto di giovar altrui (gia fa duoi anni) mi resuiglio, \& mi prouoco di nuouo a cosi gran manifattura, laqual manifattura da quella hora in qua ho proseguita, \& con grandißima celerita dubitandomi, che da morte, ouer da infermita, ouer da qualche altro strano caso non esser un'altra uolta impedito, \& disturbato. Talmente che con l'aiuto di colui, che il tutto rege, la ho ridotta a fine, \& questa mia cosi longa fatica mi é parso da diuidere in sei parti distinte, per causa della diuersita di suoi soggetti, dellequai sei parti, questa è la prima in diecissete libri diuisa, nellaquale si dichiara tutte quelle operationi praticali, \& regole necessarie, non solamente in tutta l'arte negotiaria, \& mercantile, ma anchora in ogni altra arte, scientia, ouer disciplina, doue interuenghi calculo, laqual prima parte honorando signor compare, non per satisfattione, ma per non parer scordeuole di beneficij da uostra signoria riceuuti, a quella la dedico, \& offerisco insieme con me medesimo, suo compositore, pregando il summo Iddio, che longo tempo felicimente ui conserui secondo, che desiderati.

Di Venetia alli XXIII di Marzo.

MDLVI. Di V. S. compare Nicolo Tartaglia. 
[fol. 3r]

\section{T A V O L A D E L L A C O N I N E N T I A \\ DI CIASCVUN LIBRO, ET AQUAN- TE CARTE PRINCIPIA.}

NEL primo libro (quasi come vn prohemio) si diffinisse le specie della quantita, \& a qual scientia, arte, ouer disciplina sia sottoposta ciascuna di dette specie. Si diffinisse anchora l'Arithmetica, \& le specie di quella, e similmente la vnita insieme col numero, \& si notifica la differētia, ch'è fra il naturale, \& il mathematico nel considerar la detta vnita, \& numero, \& c. a car. 2

Nel secondo libro si assegna le specie del numero solamente in quanto aspetti alla pura pratica negotiaria, ouer mercantile, \& doppo questo s'insegna le cinque prime, \& principali operationi, atti, ouer specie della pratica di Arithmetica, cioe a rappresentar, summar, sottrar, multiplicar, \& partir di numeri simplici, ouero astratti (come costuma il mathematico) in tutti quelli modi, che sono stati vsati da nostri antichi, \& moderni pratici, con varie sorte di proue. a car. 3

Nel terzo libro si mostra pur a rappresentar, summar, sottrar, multiplicar, \& partir di numeri, secondo la consideration naturale, cioe di monete, pesi, \& misure materiali cō varie specie di proue. a c. 37

Nel quarto libro si dichiara vna certa pratica, che cōmunamente infonde la natura in ogni mercante (priuo delle regole arithmetice) con laqual pratica (pur che sappia vn puoco di multiplicar, \& partir per discorso) sapra far con summa breuita, quasi ogni difficultosa ragione, che occorrer gli possa nel vendere, \& comperare, \& questa chiamiamo pratica naturale. a car. 54

Nel quinto libro si dimostra vn'altra seconda sorte di pratica assai piu artificiosa, \& presta della precendente, \& questa chiamiamo pratica artificiale. a c. 75

Nel sesto libro s'insegna vn'altra terza sorte di pratica, che in Venetia si costuma, laqual serue pur per soluere quasi ogni difficultosa ragione, che occorrer possa al mercante nel vendere, \& comprare, \& questa chiamiamo pratica venitiana. $\quad$ a car. 99

Nel settimo libro si da il modo da saper rappresentar, summar, sottrar, multiplicar, \& partir di numeri rotti, \& d'integri, \& rotti, e per certe nuoue regole non piu audite, per lequali si apprende la ragion, et causa di tai operationi, insieme con alcune altre attioni, che in essi rotti sono necessarie, lequali sono queste, schissare, accattare, infilzare, \& traslattare con varij quesiti sopra quelli, per acuir l'ingegno di dilettanti, ouer studenti. a car. 107

Nel ottauo libro si dichiara quella general regola, laqual da pratici è detta del tre, con tutte quelle strane difficulta, che occorrer possa sopra di tal regola, \& e per diuerse vie, \& in fin di quella si da la pratica firentina, sotto breuita, per non far altro libro particolare a car. 127

Nel nono libro si tratta di alcune sorte di ragioni, che fra pratici si dicono compre, \& vendite, con le limitationi di loro guadagni, \& perdite a tanto per cento, insieme con il modo da saper conuertire, monete, pesi, $\&$ misure di vna prouintia in quelle d'vn'al tra. Et inuestendo li suoi danari in vna prouintia, \& trasportando tal comprata mercantia in vn'altra prouintia in tutto diuersa di monete, pesi, et misura dalla prima, a saper limitar (al 
prezzo, che la si vendera, ouer potra vender) il lor guadagno, ouer perdita a tanto per cento. a car. 163

Nel 10 libro si da, \& dimostra la regola del tre alla riuersa, laqual serue per calli di panni, di lane succide, cottoni, \&c. Insieme col modo di far la tauola, ouer tariffa per saper dar il calmero a pistori di quanto peso debbano far il pane rispetto al prezzo del formento, giontoui in fine la regola del 5. ouero delle cinque cose, con il modo da soluere varie sorte di ragioni a tal regola pertinenti. a car. 169

Nell 11 libro si tratta di meriti, \& sconti simplici, \& a capo d'anno, ouer altro termine, con il modo da saldar vna ragione si in tempo, come in danari, insieme con il modo di saper reccare piu pagamenti fatti, ouero da esser fatti in diuersi tempi, ouer termini a vn sol termine, insieme con il modo di saper tirar in resto vna ragione si in tempo, come in danari, interpostoui vna regola generale non pui audita, ma dal presente auttor ritrouata di saper con ragione trouar con somma breuita la differentia di duoi limitati tempi, insieme con il modo di saper summare vn terminato tempo con vn'altro terminato tempo, et assignar il termine di tal summa (dico rispetto alli millesimi di tai terminati tēpi) \& similmente a saper sottrar vn terminato tēpo d'vn'al tro terminato tēpo, et determinar il termine di tal resto rispetto alli millesimi, materia molto vtile, \& ne cessaria nelle ragioni di meriti, \& sconti, \& anchor nelle cose de astronomia, notificando varij errori cō messi da frate Luca, \& altri pratici sopra le regole di detti meriti, \& sconti fatti a capo d'anno. a c. 177

Nel 12 libro si narra, \& tratta delle compagnie in tutti quelli modi, che fra mercanti possono interuenire, giustificando molti errori, \& regole false poste da fra Luca sopra quelle, \& similmente da Pietro Borgo, \& Giouan Sfortunati Senese, \& altri. Giontoui in fine il modo da risoluere varie, \& diuerse questioni, che occorrer possono sopra li sozzidi di bestiami, che per tutta Italia si costumano a [fol. 3v] dare a malghesi, pecorari, contadini a certi tempi limitati per esser tai casi, ouero questioni poco differenti dalle compagnie a car. 195

Nel 13 libro si tratta di baratti in'tutti quelli strani mo di, che immaginar di possa di poter occorrere fra mercanti, notificando varij, \& diuersi errori, \& regole false date da fra Luca dal Borgo sopra quelli \& da altri. a car. 210

Nel 14 libro si narra, \& tratta delle ragioni di cambi, \& delle quattro specie di quelli, cioe cambio minuto, ouer commune, cambio reale, cambio secco, \& cambio fittitio, \& della forma delle lor lettere, \& della vsanza di termini fra l'una, \& l'altra citta di pagar quelle con molte belle, \& sottile questioni po ste sopra ciascuna delle dette quattro specie c. 220

Nel 15 libro si tratta del ligar di metalli (cioe oro, argento, \& rame, ouer altra materia) \& del consolar di monete, \& si da regole generali di sap[er] rettamente risoluere qual si voglia passo, caso, ouer questione, che immaginar si possa, poter occorrere in vna cecca, $\&$ nell'arte di orefici. a car. 232

Nel 16 libro si narra, \& tratta della prima parte, ouer specie delle regole Helcataym (vocabolo Arabo) che in nostra lingua vuol dire delle positioni false, \& la prima parte, ouer specie di tai positioni false è detta position sempia, ouero position prima, \& oltra la detta position sempia vi s'interpone, \& mostra per forza, \& virtu di numeri, a far molti ammiratiui giuochi, \& altri casi piaceuoli da proponere doppo cena la sera al fuoco, 
delliquali oltra lo appiacere, che di quelli se ne cauara, se ne potra vin cer qualche scotto, vi s'interpone ancora varie, \& diuerse strauacanti questioni. a car. 240

Nel 17. \& vltimo libro, si dichiara con varij essempij la seconda parte delle regole Helcataym, detta position doppia. 